Rhode Island College

Digital Commons @ RIC

\title{
A Systematic Review Comparing Ephedrine Versus Phenylephrine During Spinal Anesthesia for Cesarean Delivery
}

Shelby Sullivan

Follow this and additional works at: https://digitalcommons.ric.edu/etd

Part of the Maternal, Child Health and Neonatal Nursing Commons

\section{Recommended Citation}

Sullivan, Shelby, "A Systematic Review Comparing Ephedrine Versus Phenylephrine During Spinal Anesthesia for Cesarean Delivery" (2017). Master's Theses, Dissertations, Graduate Research and Major Papers Overview. 197.

https://digitalcommons.ric.edu/etd/197

This Major Paper is brought to you for free and open access by the Master's Theses, Dissertations, Graduate Research and Major Papers at Digital Commons @ RIC. It has been accepted for inclusion in Master's Theses, Dissertations, Graduate Research and Major Papers Overview by an authorized administrator of Digital Commons @ RIC. For more information, please contact digitalcommons@ric.edu. 


\title{
A SYSTEMATIC REVIEW COMPARING EPHEDRINE VERSUS PHENYLEPHRINE DURING SPINAL ANESTHESIA FOR CESAREAN DELIVERY
}

by

\author{
Shelby Sullivan
}

A Major Paper Submitted in Partial Fulfillment

of the Requirements for the Degree of

Master of Science in Nursing

in

The School of Nursing

Rhode Island College 


\begin{abstract}
This systematic review compared the efficacy and safety of ephedrine with phenylephrine for the treatment of hypotension during spinal anesthesia for cesarean delivery. Hypotension during cesarean section delivery can have detrimental effects on both the mother and the neonate. Some vasoactive medications such as ephedrine and phenylephrine have been found to be detrimental to the neonate and divert fetal blood flow. After a systematic search of the electronic database PubMed, the Preferred Reporting Items for Systematic Reviews and Meta-Analyses (PRISMA) flowchart was used to identify appropriate research. Studies were illustrated in a table to identify key variables and were then critically appraised. Outcomes included oxygen supplementation use, ASA classification, IV fluid prehydration, hypotension incidence after spinal anesthesia, spinal solution and technique, umbilical artery $\mathrm{pH}$, Apgar scores, and nausea and vomiting during the case. Findings revealed no difference in the use of oxygen supplementation, ASA classification, IV fluid prehydration, spinal solution or technique on fetal umbilical artery $\mathrm{pH}$. Women given phenylephrine had neonates with higher umbilical artery $\mathrm{pH}$ values than those given ephedrine but there was no significant difference between the two vasopressors in the incidence of true fetal acidosis (umbilical artery $\mathrm{pH}<7.20$ or Apgar $<7$ at 1 and $5 \mathrm{~min}$ ). There was an incidental finding from two studies that additionally examined nausea and vomiting that there was an increase occurrence of nausea and vomiting with ephedrine administration as compared to phenylephrine administration. This systematic review supports the view that ephedrine and phenylephrine have equal efficacy and safety when administered to obstetric patients experiencing hypotension after spinal anesthesia during cesarean sections.
\end{abstract}




\section{Table of Contents}

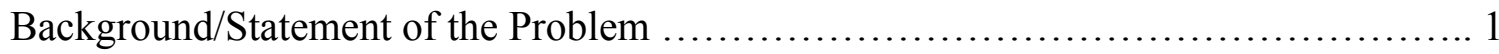

Literature Review .......................................................... 3

Theoretical Framework ................................................... 10

Methods .................................................................... 15

Results ................................................................. 19

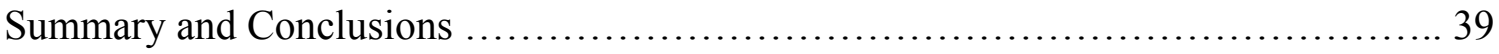

Recommendations and Implications for Advanced Nursing Practice .................. 43

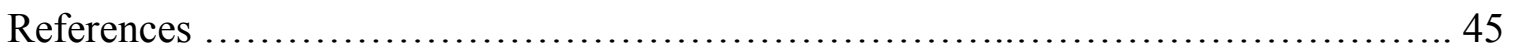

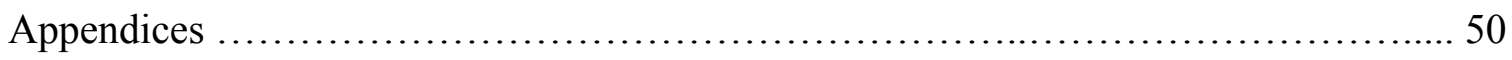


A Systematic Review Comparing Ephedrine versus Phenylephrine during Spinal Anesthesia for Cesarean Delivery

\section{Background/Statement of the Problem}

Hypotension during spinal anesthesia for elective caesarean delivery occurs in about $70-80 \%$ of cases (Mercier, Augè, Hoffmann, Fischer \& Le Gouez, 2013) and may have detrimental effects on both the mother and the neonate (lee, Kee \& Gin 2002). These effects include decreased uteroplacental blood flow, impaired fetal oxygenation with asphyxial stress and fetal acidosis (Lee et al., 2002). Associated effects include maternal symptoms of low cardiac output such as dizziness and decreased consciousness, usually requiring vasoactive drugs as treatment (Lee et al.). Some vasoactive medications have been found to be detrimental to the neonate and divert fetal blood flow, potentially causing more harm than good in pregnant women (Nagelhout, Elisha \& Plaus, 2013). Ephedrine and phenylephrine are two vasoactive drugs that reportedly do not change the blood flow to the fetus and therefore are drugs of choice in obstetric patients (Nagelhout et al.). An important clinical question is which vasoactive drug is best for these patients?

Studies have shown that ephedrine can cause fetal acidosis as a side effect and more so than phenylephrine; concerns about the adverse effects of phenylephrine on uterine blood flow have also been reported (Nagelhout et al., 2013). Ephedrine is a mixed acting adrenergic receptor agonist that has both alpha and beta agonist properties (Nagelhout et al.). Ephedrine's predominant beta effect causes an increase in arterial pressure by increasing cardiac output rather than by vasoconstriction (Nagelhout et al.). Phenylephrine is a pure alpha-adrenergic agonist which increases the blood pressure through peripheral vasoconstriction (Nagelhout et al.). A literature review of vasoactive 
drugs conducted on animals varies in terms of the safety and efficacy of the two drugs. The results may not apply to the human populations and may not be appropriate because of the species differences (Lee et al., 2002).

The purpose of this paper was to conduct a systematic review to compare the safety and efficacy of the use of ephedrine versus phenylephrine in managing maternal hypotension during spinal anesthesia for cesarean delivery. The effect of ephedrine and phenylephrine on uteroplacental blood flow and fetal outcome will be specifically examined.

Next, the review of the literature will be presented. 


\section{Literature Review}

A search was conducted using PubMed. Key terms searched were cesarean delivery, cesarean delivery complications, spinal anesthesia, hypotension, maternal hypotension, ephedrine, phenylephrine, vasoactive medications, fetal acidosis, uteroplacental blood flow and impaired fetal oxygenation. The time limit of the search was from January 2001 to January 2017.

\section{Cesarean Deliveries and Spinal Anesthesia}

Cesarean sections (C-sections) are the most commonly performed operation in the United States (US) (Gunda, Malinowski, Tegginmath, Suryanarayana \& Chandra, 2010). As reported by the Center for Disease Control and Prevention, birth by C-section accounts for over $32 \%$ of all deliveries and is performed over 1.2 million times annually in the US. The indications for C-sections include fetal positioning, declining fetal status, the failure to progress, malpresentation, cephalopelvic disproportion (CPD), prematurity, prior cesarean delivery and prior uterine surgery (Nagelhout et al.).

Regional anesthesia in C-sections offers a significant benefit over general anesthesia. Spinal anesthesia provides a rapid onset of dense symmetrical anesthesia and has an endpoint of cerebrospinal fluid as confirmation of placement (Suresh, Segal, Preston, Fernando \& Mason, 2012). Spinal anesthetics are relatively inexpensive and have become the preferred anesthetic because of the superior quality of surgical anesthesia, shorter onset time, less patient discomfort, and fewer complications than with epidural and general anesthesia (Suresh et al.). 
Although there are several benefits to using spinal anesthesia, it is not without complications. Hypotension is the most common side effect of spinal anesthesia because of the profound sympathectomy produced (Suresh et al.).

\section{Maternal Hypotension: Definition and Contributing Factors}

Maternal hypotension is defined as a $20 \%$ decrease from baseline or a systolic pressure less than $100 \mathrm{mmHg}$ (Nagelhout et al., 2013). Several factors in pregnancy physiology along with local anesthetic pharmacodynamics can contribute to the high incidence and severity of hypotension under spinal anesthesia: the level of the block; the concentration or density of the sensory block required for the procedure; local anesthetic sympathetic block; the role of aortocaval compression; and a decrease in arteriolar tone (Mercier et al., 2013).

The level of block contributes to maternal hypotension due to the vasodilating effects of the local anesthetic combined with the anatomical position at which the block is being administered and concentration of arteries and veins in the area (Miller \& Pardo, 2011). The greater the concentration of the block or denisty of the block, along with the greater presence of arteries and/or veins in the anatomical area, the more likely to result in an increased sympathectomy and therefore hypotension (Miller \& Pardo). Local anesthetics also cause a sympathetic block and therefore result in parasympathetic override which can result in hypotension due to a decrease in venous return to the heart, a decrease in cardiac output and a decrease in systemic vascular resistance (Miller \& Pardo). Local anesthetics vasodilator effect largely impacts arteries, resulting in a decrease in arteriolar tone which can contribute to the incidence and severity of hypotension in spinal anesthesia (Miller \& Pardo). This decrease in arteriolar tone is the 
main mechanism and supports why vasopressors are the most important option in the management of hypotension (Mercier et al., 2013).

Aortocaval compression, defined as compression of the vena cava when lying in the supine position due to the gravid uterus, causes a decrease in venous return to the heart and therefore hypotension. This can significantly contribute to the hypotension already caused by local anesthetics vasodilation (Nagelhout, et al., 2013). Aortocaval compression is a major contributor to hypotension in pregnant women based on female physiology and is a syndrome of supine hypotension in term or near-term pregnant women (Nagelhout et al.). The compression of the vena cava can worsen when the abdomen is tense or when the uterus is larger than normal. This decrease in venous return results in a significant reduction in stroke volume and decreases cardiac output. Nagelhout et al. elaborated that the normal physiological response to aortocaval compression is tachycardia and vasoconstriction of the lower extremities. Despite this compensation, uterine blood flow and therefore fetal oxygenation is reduced.

Compression of the aorta and vena cava is usually relieved by shifting the uterus to the left. Prevention of aortocaval compression is universally recommended to prevent hypotension and avoid the risk of abrupt fall in venous return and thus decreased cardiac output and blood pressure (Mercier et al., 2013). During patient placement for cesarean delivery, a wedge placed under the right hip or operating room table tilted left is used to relieve aorta or vena cava compression (Mercier et al.).

\section{Maternal Hypotension and Fetal Acidosis with Spinal Anesthesia}

Prolonged maternal hypotension may result in uteroplacental hypo-perfusion and therefore fetal acidosis (Gunda et al., 2010). Fetal hypoxia can occur when maternal 
perfusion of the placenta is reduced or delivery of oxygenated blood from the placenta to the fetus is impeded (Omo-Aghoja, 2014). When fetal hypoxia is present, metabolism proceeds via an anaerobic pathway and therefore lactic acid is produced, which can accumulate and result in metabolic acidosis (Omo-Aghoja). Umbilical cord blood sampling is performed to examine blood from the fetal umbilical cord to detect fetal abnormalities (Huch, Huch \& Rooth, 1994). Blood from the umbilical vein reflects the placental function whereas blood from the umbilical arteries reflects blood coming from the fetus (Huch et al.). Hypo-perfusion on the maternal side can cause a decrease in partial pressure of oxygen (PO2) in the umbilical vein; a low umbilical artery oxygen level ( $\mathrm{PaO} 2)$ indicates a risk of fetal tissue hypoxia (Huch et al.). Umbilical cord blood sampling is indicated when umbilical cord blood gas levels and percent of hydrogen $(\mathrm{pH})$ are needed to aid in the diagnosis of certain conditions such as fetal acidosis (Huch et al.). Fetal acidosis is defined as a pH less than 7.16, with adverse neonatal outcomes occurring with a pH less than 7.0 (Omo-Aghoja, 2014).

The Apgar score provides an accepted and convenient method for reporting the status of the newborn infant immediately after birth (American Academy of Pediatrics, 2015). The Apgar score is comprised of five components including color, heart rate, reflexes, muscle tone, and respirations. Each element is given a score of 0,1 , or 2 . The score is reported at one minute and five minutes after birth for all infants and at five minute intervals after that for infants with a score less than 7, up to 20 minutes (American Academy of Pediatrics). The Apgar score quantifies clinical signs of neonatal depression with free signs of cyanosis, pallor, bradycardia, depressed reflex response to stimulation, 
hypotonia and apnea or gasping respirations. All of these symptoms may be present when a neonate experiences fetal acidosis (American Academy of Pediatrics).

\section{Treatment of Maternal Hypotension}

Vasopressors are the most important option in the management of hypotension (Mercier et al., 2013). Ephedrine and phenylephrine are two vasoactive drugs that have been reported to not change the blood flow to the fetus and therefore are drugs of choice in obstetric patients (Nagelhout et al., 2013). Until recently, ephedrine was the more favored agent in treating maternal hypotension but several studies have shown that ephedrine risk may outweigh its benefits. As a result, there has been an increase in practitioners' use of phenylephrine to treat maternal hypotension (Mercier et al., 2013). Each drug will be briefly reviewed next.

\section{Ephedrine: Pharmacokinetics and Indications for Treatment of Maternal}

Hypotension. Ephedrine is a mixed acting adrenergic receptor agonist that has both alpha and beta agonist properties (Nagelhout et al., 2013). The adopted use of ephedrine was initially supported by a study conducted by Ralston and Shnider (1974) that examined sheep to determine uterine blood flow with different vasopressors. Results showed that ephedrine preserved uterine blood flow, while drugs with increasing alpha agonist properties produced potent vasoconstriction of the uterine vascular bed. A landmark study performed by Kang in 1982 showed that a continuous infusion of ephedrine was extremely effective at preventing maternal hypotension during elective caesarean delivery versus a control group that received ephedrine only when hypotension occurred. Ralston and Shnider's study results were reinforced when McGrath et al. (1994) performed a similar study with a randomized design. These authors confirmed that unlike 
phenylephrine, ephedrine improved uterine blood flow without increasing uterine vascular resistance when given after epidural anesthesia-induced hypotension. Later studies, which will be reported in the next section, compared the use of ephedrine and phenylephrine.

\section{Phenylephrine: Pharmacokinetics and Indications for Treatment of}

Maternal Hypotension. Phenylephrine is a pure alpha-adrenergic agonist that increases the blood pressure through peripheral vasoconstriction (Nagelhout et al.). In the 1990s, phenylephrine began to be used more cautiously in clinical practice as a rescue vasopressor to control maternal hypotension, tachycardia and other symptoms when ephedrine had failed (Taylor \& Tunstall, 1991). Subsequently, direct comparison of ephedrine and phenylephrine began to challenge the standard use of ephedrine by reporting that the pure alpha agonist produced a better umbilical artery $\mathrm{pH}$ (Morgan, 1994). In 2002, Lee et al. performed a meta-analysis of six trials $(n=200)$ comparing ephedrine and phenylephrine used to treat maternal hypotension with spinal anesthesia for cesarean delivery. Results suggested that phenylephrine resulted in better umbilical arterial $\mathrm{pH}$ than ephedrine but no difference in the incidence of true fetal acidosis or Apgar score below 7 at 1 minute (RR of $0.77 ; 95 \% \mathrm{CI}, 0.17-3.51$ ) and five minutes (RR of 1.00; 95\% CI, 0.21-4.83) after birth. Pooling the results showed that women given phenylephrine had neonates with higher umbilical arterial $\mathrm{pH}$ values than those given ephedrine (WMD $=0.03 ; 95 \% \mathrm{CI}, 0.02-0.04$, mean ephedrine umbilical arterial $\mathrm{pH}$ values ranging from 7.27-7.29). Also, women given phenylephrine had neonates with greater venous $\mathrm{pH}$ values than those given ephedrine $(\mathrm{WMD}=0.02 ; 95 \% \mathrm{CI}, 0.01-0.03$, mean ephedrine venous $\mathrm{pH}$ values ranging from 7.29-7.35). The risk of true fetal 
acidosis, which was defined as a $\mathrm{pH}$ value of $<7.20$, was similar between the phenylephrine and ephedrine groups ( $\mathrm{RR}$ of $0.78 ; 95 \% \mathrm{CI}, 0.16-3.92)$ (Lee et al.).

Phenylephrine has been demonstrated to be detrimental to the well-being of the fetus, based on numerous animal models (Mercier et al., 2013). When ephedrine began to be reported to cross the placental barrier easily and cause a decrease in umbilical arterial $\mathrm{pH}$ or ephedrine failed to treat the maternal hypotension, phenylephrine began to be used cautiously (Mercier et al.). While phenylephrine effectively prevents hypotension and provides a proper neonatal $\mathrm{pH}$, it can cause bradycardia (Mercier et al.). The mechanism is thought to be due to a baroreceptor-mediated response in cardiac afterload due to increased systemic vascular resistance. The response may also be due to cardiac sympathetic denervation associated with spinal blocks which could be masked when ephedrine is used because of its beta-adrenergic chronotropic effect (Mercier et al.). This bradycardia may result in a decrease in cardiac output which can further harm the fetus (Mercier et al.). Further analysis of ephedrine and phenylephrine specific to impact on maternal hypotension and fetal outcomes is indicated.

Next, the frameworks used to guide this review will be presented. 


\section{Theoretical Frameworks}

Systematic reviews and meta-analyses are a vital component of evidence-based healthcare and as such they support the development of clinical practice guidelines and inform clinical decision-making (Moher et al., 2015). The Preferred Reporting Items for Systematic Reviews and Meta-Analyses (PRISMA) is used to accurately report highquality systematic reviews as well as meta-analyses. PRISMA was created in 2009 after the previously used Quality of Reporting of Meta-Analysis (QUOROM) statement (1999) was revised (Atlman et al., 2009). The new PRISMA statement allows for standardization and improvement of the quality of the systematic reviews being produced (Atlman et al.). Although the PRISMA update in 2009 was thought to correct many missing pieces and to promote consistency to systematic review research, there remained the issue of how to include studies with greater than two interventions. To address this issue, experts in research added five more items to the checklist, in the methodology section (Moher et al., 2015). Since this author will only be examining two primary variables, ephedrine and phenylephrine, the 2009 PRISMA checklist, as well as the 2009 flow diagram, will be used. The flowchart was modified to include the number of articles identified, those included as well as those excluded (Moher et al., 2009). The 27-item checklist was created with items thought to be necessary for transparency of data (Moher et al.). The items on the checklist give researchers a step-by-step guide while allowing them to present their research in an accurate and succinct manner (Moher et al.).

The PRISMA statement consists of a 27 item checklist (Table 1) which lays out the requirements for evidence-based studies (Moher et al., 2009). Table 1 can be viewed on the next page. Items on the checklist include seven major sections including title, 
abstract, introduction, methods, results, discussion, and funding. Within each heading are

subheadings as well as descriptions defining the expectations for each of the sections.

The PRISMA checklist will be used to ensure that all items required to complete a

systematic review are presented in the completion of the research.

Table 1

PRISMA Checklist

\begin{tabular}{|c|c|c|c|}
\hline Section/Topic & $\begin{array}{l}\text { Item } \\
\#\end{array}$ & Checklist Item & $\begin{array}{l}\text { Reported on } \\
\text { Page \# }\end{array}$ \\
\hline \multicolumn{4}{|l|}{ TITLE } \\
\hline Title & 1 & Identify the report as a systematic review, meta-analysis, or both. & \\
\hline \multicolumn{4}{|l|}{ ABSTRACT } \\
\hline Structured summary & 2 & $\begin{array}{l}\text { Provide a structured summary including, as applicable: background; objectives; data sources; study } \\
\text { eligibility criteria, participants, and interventions; study appraisal and synthesis methods; results; } \\
\text { limitations; conclusions and implications of key findings; systematic review registration number. }\end{array}$ & \\
\hline \multicolumn{4}{|l|}{ INTRODUCTION } \\
\hline Rationale & 3 & Describe the rationale for the review in the context of what is already known. & \\
\hline Objectives & 4 & $\begin{array}{l}\text { Provide an explicit statement of questions being addressed with reference to participants, } \\
\text { interventions, comparisons, outcomes, and study design (PICOS). }\end{array}$ & \\
\hline \multicolumn{4}{|l|}{ METHODS } \\
\hline Protocol and registration & 5 & $\begin{array}{l}\text { Indicate if a review protocol exists, if and where it can be accessed (e.g., Web address), and, if } \\
\text { available, provide registration information including registration number. }\end{array}$ & \\
\hline Eligibility criteria & 6 & $\begin{array}{l}\text { Specify study characteristics (e.g., PICOS, length of follow-up) and report characteristics (e.g., } \\
\text { years considered, language, publication status) used as criteria for eligibility, giving rationale. }\end{array}$ & \\
\hline Information sources & 7 & $\begin{array}{l}\text { Describe all information sources (e.g., databases with dates of coverage, contact with study } \\
\text { authors to identify additional studies) in the search and date last searched. }\end{array}$ & \\
\hline Search & 8 & $\begin{array}{l}\text { Present full electronic search strategy for at least one database, including any limits used, such } \\
\text { that it could be repeated. }\end{array}$ & \\
\hline Study selection & 9 & $\begin{array}{l}\text { State the process for selecting studies (i.e., screening, eligibility, included in systematic review, } \\
\text { and, if applicable, included in the meta-analysis). }\end{array}$ & \\
\hline Data collection process & 10 & $\begin{array}{l}\text { Describe method of data extraction from reports (e.g., piloted forms, independently, in duplicate) } \\
\text { and any processes for obtaining and confirming data from investigators. }\end{array}$ & \\
\hline Data items & 11 & $\begin{array}{l}\text { List and define all variables for which data were sought (e.g., PICOS, funding sources) and any } \\
\text { assumptions and simplifications made. }\end{array}$ & \\
\hline $\begin{array}{l}\text { Risk of bias in individual } \\
\text { studies }\end{array}$ & 12 & $\begin{array}{l}\text { Describe methods used for assessing risk of bias of individual studies (including specification of } \\
\text { whether this was done at the study or outcome level), and how this information is to be used } \\
\text { in any data synthesis. }\end{array}$ & \\
\hline Summary measures & 13 & State the principal summary measures (e.g., risk ratio, difference in means). & \\
\hline Synthesis of results & 14 & $\begin{array}{l}\text { Describe the methods of handling data and combining results of studies, if done, including } \\
\left.\text { measures of consistency (e.g., }\left.\right|^{2}\right) \text { for each meta-analysis. }\end{array}$ & \\
\hline $\begin{array}{l}\text { Risk of bias across } \\
\text { studies }\end{array}$ & 15 & $\begin{array}{l}\text { Specify any assessment of risk of bias that may affect the cumulative evidence (e.g., publication } \\
\text { bias, selective reporting within studies). }\end{array}$ & \\
\hline Additional analyses & 16 & $\begin{array}{l}\text { Describe methods of additional analyses (e.g., sensitivity or subgroup analyses, meta-regression), if } \\
\text { done, indicating which were pre-specified. }\end{array}$ & \\
\hline \multicolumn{4}{|l|}{ RESULTS } \\
\hline Study selection & 17 & $\begin{array}{l}\text { Give numbers of studies screened, assessed for eligibility, and included in the review, with reasons } \\
\text { for exclusions at each stage, ideally with a flow diagram. }\end{array}$ & \\
\hline Study characteristics & 18 & $\begin{array}{l}\text { For each study, present characteristics for which data were extracted (e.g., study size, PICOS, } \\
\text { follow-up period) and provide the citations. }\end{array}$ & \\
\hline $\begin{array}{l}\text { Risk of bias within } \\
\text { studies }\end{array}$ & 19 & $\begin{array}{l}\text { Present data on risk of bias of each study and, if available, any outcome-level assessment (see } \\
\text { Item 12). }\end{array}$ & \\
\hline $\begin{array}{l}\text { Results of individual } \\
\text { studies }\end{array}$ & 20 & $\begin{array}{l}\text { For all outcomes considered (benefits or harms), present, for each study: (a) simple summary data } \\
\text { for each intervention group and (b) effect estimates and confidence intervals, ideally with a } \\
\text { forest plot. }\end{array}$ & \\
\hline Synthesis of results & 21 & $\begin{array}{l}\text { Present results of each meta-analysis done, including confidence intervals and measures of } \\
\text { consistency. }\end{array}$ & \\
\hline $\begin{array}{l}\text { Risk of bias across } \\
\text { studies }\end{array}$ & 22 & Present results of any assessment of risk of bias across studies (see Item 15). & \\
\hline Additional analysis & 23 & $\begin{array}{l}\text { Give results of additional analyses, if done (e.g., sensitivity or subgroup analyses, meta-regression } \\
\text { [see Item 16]). }\end{array}$ & \\
\hline \multicolumn{4}{|l|}{ DISCUSSION } \\
\hline Summary of evidence & 24 & $\begin{array}{l}\text { Summarize the main findings including the strength of evidence for each main outcome; consider } \\
\text { their relevance to key groups (e.g., health care providers, users, and policy makers). }\end{array}$ & \\
\hline Limitations & 25 & $\begin{array}{l}\text { Discuss limitations at study and outcome level (e.g., risk of bias), and at review level (e.g., } \\
\text { incomplete retrieval of identified research, reporting bias). }\end{array}$ & \\
\hline Conclusions & 26 & $\begin{array}{l}\text { Provide a general interpretation of the results in the context of other evidence, and implications } \\
\text { for future research. }\end{array}$ & \\
\hline \multicolumn{4}{|l|}{ FUNDING } \\
\hline Funding & 27 & $\begin{array}{l}\text { Describe sources of funding for the systematic review and other support (e.g., supply of data); } \\
\text { role of funders for the systematic review. }\end{array}$ & \\
\hline
\end{tabular}


Along with the checklist is the PRISMA four-phase flow diagram (Figure 1) that helps to dictate the literature search procedure (Moher et al.,). The flow chart illustrated below elucidates the screening and evaluation for eligibility within the research.

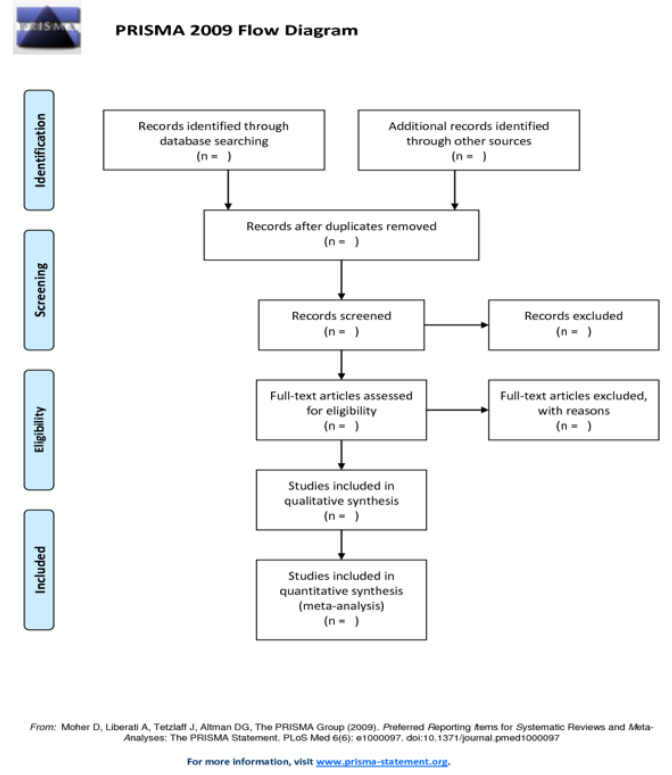

Figure 1. PRISMA Flow Diagram. This figure illustrates the PRISMA statements flow diagram used for the search strategy performed when conducting a systematic review and to evaluate the eligibility of studies.

The Preferred Reporting Items for Systematic Reviews and Meta-Analyses flowchart supports the attainment of appropriate research. This flowchart also provides a step-by-step set of instructions for articles included for analysis. The flow diagram outlines the records excluded from the study and ask for reasons why to be reported (Moher et al., 2009). It begins with the identification of articles through database searching, the screening of such items for appropriateness and eligibility, and ends with the final articles to be included within the research; the process can be reviewed in Figure 
1 (Moher et al., 2009). PRISMA may also be useful for critical appraisal of published systematic reviews but is not a quality assessment instrument (Moher et al.)

The Critical Appraisal for Summaries of Evidence (CASE) worksheet (Table 2) is used to assess the quality of evidence (Foster \& Shurtz, 2013) and will be used to critically appraise the studies.

Table 2

CASE Worksheet

\begin{tabular}{|c|c|}
\hline \multicolumn{2}{|c|}{$\begin{array}{l}\text { Critical Appraisal for Summaries of Evidence (CASE) Worksheet } \\
\text { *Numbers in evaluation correspond with those assigned to articles in data extrapolation chart* }\end{array}$} \\
\hline Questions & Evaluation \\
\hline \multicolumn{2}{|c|}{ Summary Topic } \\
\hline $\begin{array}{l}\text { 1. Is the summary specific in scope and } \\
\text { application? }\end{array}$ & $\begin{array}{l}\text { Yes- } \\
\text { Not completely- } \\
\text { No- }\end{array}$ \\
\hline \multicolumn{2}{|c|}{ Summary Methods } \\
\hline $\begin{array}{l}\text { 2. Is the authorship of the summary } \\
\text { transparent? }\end{array}$ & $\begin{array}{l}\text { Yes- } \\
\text { Not completely- } \\
\text { No- }\end{array}$ \\
\hline $\begin{array}{l}\text { 3. Are the reviewer(s)/editor(s) of the } \\
\text { summary transparent? }\end{array}$ & $\begin{array}{l}\text { Yes- } \\
\text { Not completely- } \\
\text { No- }\end{array}$ \\
\hline $\begin{array}{l}\text { 4. Are the research methods transparent } \\
\text { and comprehensive? }\end{array}$ & $\begin{array}{l}\text { Yes- } \\
\text { Not completely- } \\
\text { No- }\end{array}$ \\
\hline $\begin{array}{l}\text { 5. Is the evidence grading system } \\
\text { transparent and translatable? }\end{array}$ & $\begin{array}{l}\text { Yes- } \\
\text { Not completely- } \\
\text { No- }\end{array}$ \\
\hline \multicolumn{2}{|c|}{ Summary Content } \\
\hline 6. Are the recommendations clear? & $\begin{array}{l}\text { Yes- } \\
\text { Not completely- } \\
\text { No- }\end{array}$ \\
\hline $\begin{array}{l}\text { 7. Are the recommendations appropriately } \\
\text { cited? }\end{array}$ & $\begin{array}{l}\text { Yes- } \\
\text { Not completely- } \\
\text { No- }\end{array}$ \\
\hline 8. Are the recommendations current? & $\begin{array}{l}\text { Yes- } \\
\text { Not completely- } \\
\text { No- }\end{array}$ \\
\hline 9. Is the summary unbiased? & $\begin{array}{l}\text { Yes- } \\
\text { Not completely- } \\
\text { No- }\end{array}$ \\
\hline \multicolumn{2}{|c|}{ Summary Application } \\
\hline $\begin{array}{l}\text { 10. Can this summary be applied to your } \\
\text { patient(s)? }\end{array}$ & $\begin{array}{l}\text { Yes- } \\
\text { Not completely- } \\
\text { No- }\end{array}$ \\
\hline
\end{tabular}

The CASE worksheet is comprised of 10 questions examining specificity, authorship, reviewers, methods, grading, clarity, citations, currency, bias, and relevancy 
of each study (Foster \& Shurtz, 2013). The researcher must answer these questions as either "yes", "no", or "not completely". Traditionally, the CASE worksheet is utilized to assess the quality of point-of-care tools and treatment modalities that directly effect patient outcomes. The quality assessment data within the studies will be determined through the application of the CASE Worksheet. Each study will be appraised through answering the ten CASE worksheet questions and then all the studies will be compared based on the results and listed from highest to lowest quality, one being the highest quality and five being the lowest quality based on the CASE worksheet results. Cross study analysis was conducted using a process called descriptive data synthesis, which can be accomplished by both a narrative and a tabulation approach (Evans, 2002). This process will be further described in the methods section. Next, the methods used to conduct this systematic review will be discussed. 


\section{Method}

\section{Purpose of Study/Clinical Question}

The purpose of this systematic review was to compare the safety and efficacy of the use of ephedrine versus phenylephrine in managing maternal hypotension during spinal anesthesia for cesarean delivery. The effects of ephedrine and phenylephrine on uteroplacental blood flow and fetal outcome was specifically examined.

The question posed was: Is either ephedrine or phenylephrine more effective and safer when used to treat hypotension during spinal anesthesia for cesarean delivery?

\section{Outcomes Examined}

The specific outcomes assessed included maternal blood pressure, maternal heart rate, fetal acidosis as measured by neonatal umbilical cord blood arterial and/or venous $\mathrm{pH}$ and Apgar score.

\section{Inclusion and exclusion criteria}

Inclusion criteria encompassed: studies specific to cesarean delivery with spinal anesthesia that examined: maternal hypotension; ephedrine and phenylephrine; fetal acidosis with or without Apgar scores. Only randomized control trials or systematic reviews published from January 2001 to January 2017 were included. Exclusion included any studies before January 2001 and those not meeting all of the inclusion criteria.

\section{Search Strategy}

Applying both the PRISMA flowchart as well as the PRISMA checklist, research articles were obtained from the database PubMed. The search was conducted using the terms cesarean delivery, cesarean delivery complications, spinal anesthesia, hypotension, maternal hypotension, Ephedrine, Phenylephrine, vasoactive medications, fetal acidosis, 
uteroplacental blood flow and impaired fetal oxygenation. The results of the search were applied to the PRISMA flow diagram (Figure 1) to support selection for inclusion in the systematic review.

After removing any duplicates located, the investigator then assessed the remainder of the studies for inclusion criteria. Eligibility assessment was performed independently in an unblinded and unbiased standardized manner by the student researcher. Initial steps involved first reviewing both title and abstract for eligibility. The remaining studies were then further screened for eligibility through examination of the entire study and the reasons for exclusion of those that did not qualify was noted. The number of articles being used for data synthesis were identified (PRISMA, 2009).

\section{Data Collection for Each Study}

Table 3 served as a data collection table to organize pertinent data from each study. This table was used to organize and summarize information gathered from the research articles included in the study and ensured that all required criteria as stated by PRISMA were captured.

\section{Table 3}

Data Collection Tool

\begin{tabular}{|c|l|l|l|l|l|}
\hline $\begin{array}{c}\text { Method/Level } \\
\text { of evidence \& } \\
\text { Major } \\
\text { Variables } \\
\text { Studied }\end{array}$ & Sample/setting & Intervention & $\begin{array}{c}\text { Data } \\
\text { Analysis }\end{array}$ & Results & limitations \\
\hline & & & & & \\
\hline & & & & & \\
\hline
\end{tabular}




\section{Critical Appraisal Tool}

The purpose of a critical appraisal is to determine how credible the study is in practice (Fineout-Overholt, Melnky, Stillwell \& Williamson, 2010). The quality assessment data within the studies was determined through the application of the CASE Worksheet (Table 2) illustrated earlier in the framework section. All 10 questions examining specificity, authorship, reviewers, methods, grading, clarity, citations, currency, bias, and relevancy of each study were answered. The hierarchy of evidence for assessing healthcare research will also be used to determine the level of evidence of each study (Melnyk \& Fineout-Overholt, 2011).

\section{Descriptive data synthesis}

Descriptive data synthesis can be attained by both means of a narrative and also a tabulation approach to describe the literature (Evans, 2002). Evans (2002) stated that using both narrative and tabulation data synthesis allows a more comprehensive view of the literature by decreasing limitations than if just one method was used. A narrative was completed to summarize the studies individually as well as across each study in order to identify themes and patterns. The outcome of safety and efficacy of the use of ephedrine versus phenylephrine was examined and further tabulated into more detail in Table 4, illustrated on the next page and then examined for comparisons across the studies. 


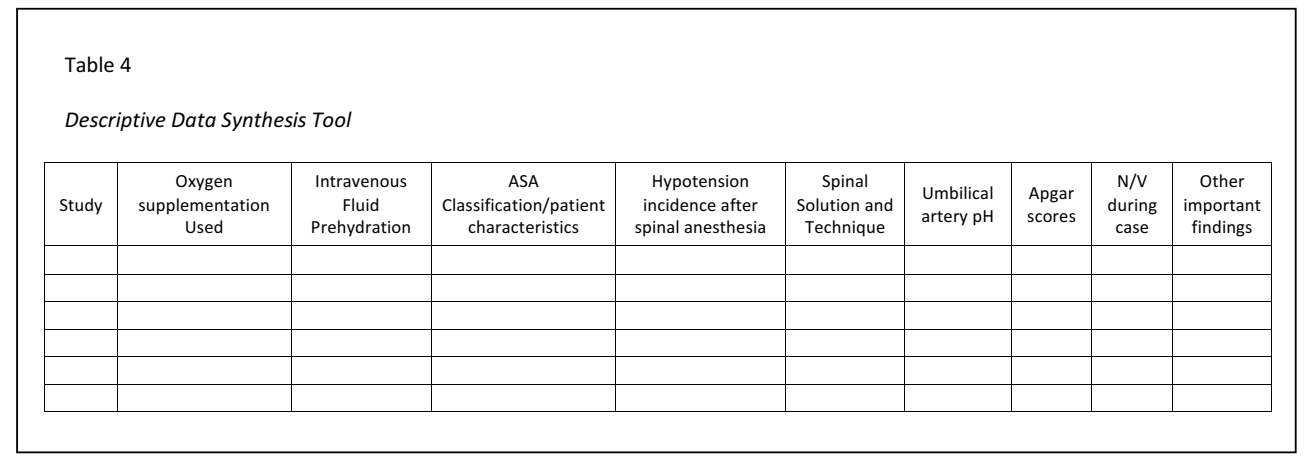

Through the descriptive data synthesis and comparison across the studies, the following questions were addressed:

- Which medication causes less umbilical cord arterial and/or venous blood acidosis: phenylephrine or ephedrine?

- Which medication causes the least decrease in infant Apgar scores: phenylephrine or ephedrine?

- Was oxygen administered to the mother during c-section and could this be correlated with fetal acidosis?

- Was the mother administered IV pre-hydration prior to the spinal that could effect the incidence of hypotension seen?

- What were the characteristics of the patient studied?

- Was there a correlation between hypotension after spinal anesthesia and the spinal anesthesia medication used?

- Were there any incidental findings that can be contributed to fetal acidosis?

Next, study results will be presented. 


\section{Results}

The PRISMA flowchart (Figure 2), illustrated below, along with the inclusion and exclusion criteria aforementioned, were used to further eliminate and select articles for the systematic review. After the database search, a total of 44 non-duplicate citations were screened. The abstracts of these articles were reviewed for evidence of exclusion criteria that would deem them not appropriate for the systematic review. This process eliminated a total of 22 articles. The remaining 22 articles were reviewed in their entirety for relevance and selected for the systematic review based on both exclusion and inclusion criteria. The final elimination process omitted 16 articles, leaving a total of six articles for inclusion within the final systematic review.

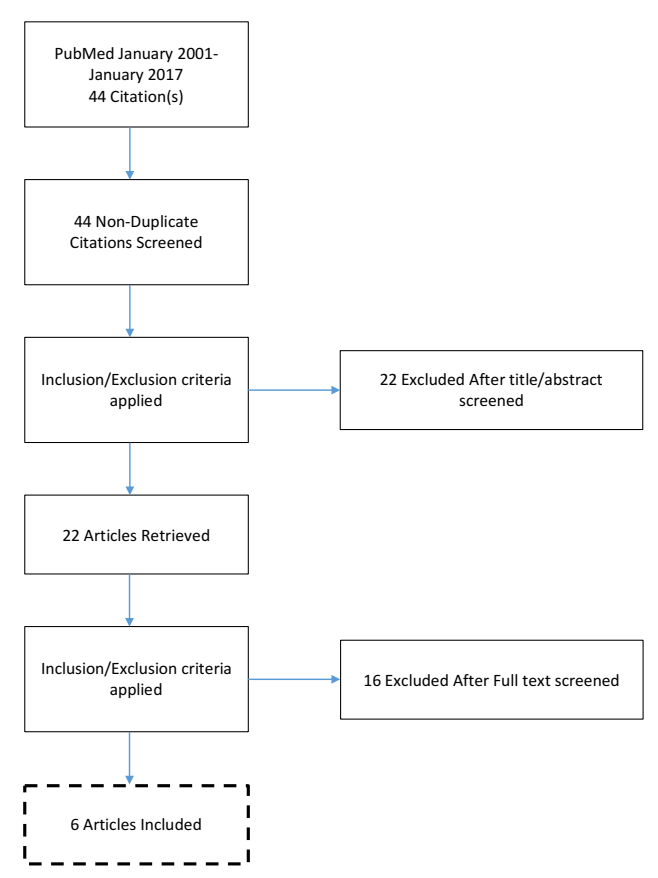

Figure 2. Search Strategy Using PRISMA Flow Diagram. This figure illustrates the search strategy performed and applies the results found to the PRISMA flow diagram.

Of the six articles that remained, five were randomized control trials and one was a retrospective observational and chart review study. The following section summarizes 
each individual study as derived from the data collection tool (Appendix A) after the summary of each study, a critical analysis of the study is provided (Appendix B). The retrospective chart review will be reviewed first, followed by the RCTs which will be presented chronologically.

The retrospective observational study and chart review conducted by Cooper et al. (2010) (Appendix A-1) included 385 women with high risk pregnancies that had a cesarean section under spinal anesthesia for singleton delivery where fetal umbilical artery and venous $\mathrm{pH}$ were recorded. Charts were reviewed within a four-year period from 2000-2003. Once women for the study were identified, the authors then reviewed the notes, recording maternal and fetal demographic and operative data. Blood gas values, taken from a double clamped segment of umbilical cord at delivery and five minute Apgar scores assessed by a midwife upon admission to the neonatal unit were all recorded. During the study, ephedrine was routinely given as $6 \mathrm{mg}$ boluses and phenylephrine as $100 \mathrm{mcg}$ boluses, at the discretion of the anesthetist. Phenylephrine was started at $33 \mathrm{mcg} / \mathrm{min}$ immediately following spinal injection and then titrated, aiming to keep systolic blood pressure (SBP) at baseline. The infusion rate was doubled or halved as required. The maximum infusion rate was $67 \mathrm{mcg} / \mathrm{min}$. If there was hypotension despite the prophylactic infusion, $100 \mathrm{mcg}$ boluses of phenylephrine were given. There were no guidelines for ephedrine infusion.

One hundred and twelve participants per group would give the study an $80 \%$ chance of detecting a 0.03 difference in umbilical artery $\mathrm{pH}$, at $\mathrm{P}=0.05$, based on a standard deviation of 0.08 for umbilical artery $\mathrm{pH}$ for non-elective $\mathrm{C}$-section under spinal anesthesia. Secondary outcomes were the incidence of fetal acidosis $(\mathrm{pH}<7.20)$, low 5 
minute Apgar score $(<7)$ and admission to the neonatal unit. Mann-Whitney and KruskalWallis tests were used for direct comparison of the groups and subgroups. Forward stepwise multiple regression analysis was used to find which independent variables were associated with umbilical artery $\mathrm{pH}$. Results revealed that there was no difference in umbilical artery $\mathrm{pH}$ between the three groups on direct comparison $(\mathrm{P}=0.21)$. Following forward stepwise multiple regression analysis, the only variable that was associated with altered $\mathrm{pH}$ was non-reassuring fetal heart rate trace $(\mathrm{P}=0.71)$.

Critical analysis of the Cooper et al. (2010) study using the CASE worksheet (Appendix B-1) found that the study met six out of 10 criterions. The authors clearly identified the aim of the study as well as the patients that the study applied to. Although the individual authors were identified with their affiliations, their credentialing was not listed. Whether the study was edited or reviewed was also not clearly stated. The inclusion and exclusion criteria and protocol for the study were clearly stated. The study was a retrospective observational chart review study therefore level IV evidence based on the hierarchy of evidence (Melnyk \& Fineout-Overholt, 2011). The protocol used in reviewing the charts was clearly stated. Although recommendations for practice were not current, they were clearly stated and multiple options for treatment were provided and could be applied to any setting and population. It was unable to be determined if there was a conflict of interest.

Cooper et al. (2002) (Appendix A-2) conducted a randomized/double blind study including 147 ASA I and II women scheduled for elective C-section of a singleton pregnancy under spinal anesthesia with no other comorbidities. Before entering the operating room, vital signs were taken three times and the lowest of the three was 
considered the baseline. Baseline nausea and vomiting scores were also assessed. The participants, anesthetists, nurses and midwives involved were all blinded to the patient grouping. There were three groups: The P group received phenylephrine $100 \mathrm{mcg} / \mathrm{ml}$; the E group received ephedrine $3 \mathrm{mg} / \mathrm{ml}$; and the $\mathrm{C}$ group received a combination of phenylephrine $50 \mathrm{mcg} / \mathrm{ml}$ combined with ephedrine $1.5 \mathrm{mg} / \mathrm{ml}$. One of four spinal anesthetics techniques was used based on provider preference. Immediately before spinal anesthesia, a preload of $10 \mathrm{ml} / \mathrm{kg}$ of Hartmann solution was rapidly infused. Immediately following spinal injection, the infusion of IV vasopressor solution was started according to protocol. The patient was then positioned supine with a left lateral tilt. Systolic arterial pressure and heart rate were measured every minute. The rate of the solution was doubled or halved if the systolic arterial blood pressure (BP) fell below or above 0.75 times the baseline. Phenylephrine was started at $33 \mathrm{mcg} / \mathrm{min}$; ephedrine was started at $1 \mathrm{mg} / \mathrm{min}$ or half the dose rate for each for the combination solution. The maximum nausea and vomiting score was recorded between spinal and delivery. At delivery, one of the investigators obtained umbilical artery and vein blood samples from a segment of the umbilical cord double clamped before the babies' first breath. No supplemental O2 was given to the mother prior to delivery. The APGAR scores were recorded at one and five minutes by a midwife. The Kruskal-Wallis test was used to compare the three groups. If a difference was found with the Kruskal-Wallis test, pairs of groups were then compared using the Mann-Whitney U test. The Wilcoxon signed-rank test and spearman rank test were also used to analyze data. The Wilcoxon signed-rank test was used to compare data within a group. 
All participants were comparable for age, height, weight, gestation, breech presentation, previous c-section, delivery and birth weight. Forty-eight participants in the phenylephrine group (P group), 50 in the ephedrine group (E Group) and 49 in combination of phenylephrine and ephedrine solution group ( $\mathrm{C}$ group) were studied. Fetal acidosis was less frequent in the $\mathrm{P}$ group ( 1 of 48$)$ and less frequent in the $\mathrm{C}$ group ( 1 of 47) than in the E group (10 of 48), (overall $\mathrm{P}=0.0007)$. There was no difference in the incidence of fetal acidosis between the $\mathrm{P}$ and $\mathrm{C}$ groups $(\mathrm{P}=0.99)$. One and five min APGAR scores were normal in all three groups. Blood gas values were similar for the $\mathrm{P}$ and $\mathrm{C}$ groups; the $\mathrm{E}$ group had a lower umbilical artery $\mathrm{pH}$ than the $\mathrm{P}$ group $(\mathrm{P}=0.002)$ or the $\mathrm{C}$ group $(\mathrm{P}=0.009)$ and a lower umbilical vein $\mathrm{pH}$ than the $\mathrm{P}$ group $(\mathrm{P}=0.04)$ or the $\mathrm{C}$ group $(\mathrm{P}=0.003)$. There was no difference in the umbilical vein $\mathrm{PCO} 2$ between the groups but the E group had a higher umbilical artery $\mathrm{PCO} 2$ than the $\mathrm{P}$ group $(\mathrm{P}=0.002)$. There was no change in the $\mathrm{P}$ group from baseline $\mathrm{N} / \mathrm{V}$ scores $(\mathrm{P}=0.30)$ but in the $\mathrm{E}$ and C group the N/V scores increased from baseline $(E=P<0.0001)(C=P=0.007)$. The N/V scores were lower in the $\mathrm{P}$ group than in the $\mathrm{E}$ group $(\mathrm{P}<0.0001)$ or $\mathrm{C}$ group $(\mathrm{P}<0.0001)$ but there was no significant difference between the $\mathrm{E}$ and $\mathrm{C}$ groups $(\mathrm{P}=0.09)$. In the $\mathrm{E}$ group, vomiting $(\mathrm{n}=18)$ was associated with decreased HR and SABP and increased ephedrine doses. The incidence of fetal acidosis and vomiting at cesarean delivery under spinal anesthesia was reduced by giving phenylephrine alone or in combination with ephedrine versus giving ephedrine alone.

The CASE worksheet was then applied to the study by Cooper et al. (2002) (Appendix B-2). The study was found to meet seven out of ten criteria. The aim of the study was clearly stated as well as the patients that the summary applied to. The 
individual authors were listed along with their credentialing and affiliations. It was not clearly stated that the study had been edited and reviewed. The inclusion and exclusion criteria were clearly stated as well as the protocol followed for the study. This study was a randomized double-blinded study which is level II evidence (Melnyk \& FineoutOverholt, 2011). The study stated that randomization was performed by randomly allocating patients by envelope selection to one of three groups and that all participants and investigators were blinded to the group and that unlabeled syringes were used. A third party not involved in the study opened the envelope and handed the appropriate medication to the investigator. The recommendations were clearly stated and multiple options for treatment were provided. The recommendations were from 2002 and therefore not current. It was unable to determine if there was a conflict of interest between the recommendation of the summary and the sponsor for any author. The evidence and setting for this study applies to many populations and settings.

Ngan Kee et al. (2008) (Appendix A-3) performed a randomized double blind study of 204 ASA I and II women with singleton pregnancies scheduled for non-elective C-section for which spinal anesthesia was decided upon for clinical reasons at any point in time. Standard monitoring was applied. No IV prehydration was given. Spinal anesthesia was induced with the patient in the right lateral position at L3-4 or L4-5 with 2.0-2.2 $\mathrm{ml}$ of hyperbaric $0.5 \%$ bupivacaine $(10-20 \mathrm{mg})$ and fentanyl $15 \mathrm{mcg}$. The patients were then immediately turned to supine with a left lateral tilt and a rapid IV co-hydration with up to 2 liters of lactated ringer's solution was administered and oxygen of 6-8 L/min delivered by clear facemask until delivery. Participants were randomized to receive an IV bolus of either phenylephrine $100 \mathrm{mcg}$ (group P) or ephedrine $10 \mathrm{mg}$ (group E) 
immediately after each episode of hypotension. Umbilical arterial (UA) and umbilical venous (UV) blood samples from double-clamped segments of umbilical cord were obtained. The attending pediatrician assessed APGAR scores at one and five minutes after delivery. Univariate intergroup comparisons were made using the unpaired student's t-test or the Mann-Whitney U-test as appropriate. Nominal data were compared using the Chi-Square test or Fisher's exact test.

The number of doses of vasopressor required was similar between groups. More participants had nausea or vomiting in the E group than the $\mathrm{P}$ group (13/102 (12.7\%) vs 4/102 (3.9\%), $\mathrm{P}=0.02)$. There was no difference between groups in the primary outcome, UA $\mathrm{pH}$. In the E group, two cases had a $\mathrm{UA} \mathrm{pH}<7.0$ compared with no cases in the $\mathrm{P}$ group $(\mathrm{P}=0.50)$. The UA $\mathrm{PO} 2$ was lower in the $\mathrm{P}$ group vs the $\mathrm{E}$ group (median difference 0.23 [ $95 \% \mathrm{CI}$ of difference $0.20-0.45] ; \mathrm{P}=0.032$ ) and $\mathrm{UV} \mathrm{PO} 2$ was lower in the P group vs the E group (Median difference 0.39 [95\% CI of difference 0.08-0.70; $\mathrm{P}=0.012$ ). However, there was no difference between groups in UA or UV oxygen content. There was no difference between groups in the clinical outcome of the neonates. Both phenylephrine and ephedrine are suitable vasopressors for use in non-elective Csections.

The study by Ngan Kee et al. (2008) was then critically appraised using the CASE worksheet (Appendix B-3). The study met six out of 10 criterions. The aim of the study was clearly stated as well as the patients that the study applied to. Although the individual authors and their affiliations were listed in the study, their credentialing was not. It was not clearly stated that the study was edited or reviewed. The inclusion and exclusion criteria were clearly stated as well as the protocol for the study. The study is level II 
evidence being that it is a randomized double-blinded study (Melnyk \& FineoutOverholt, 2011). The study stated that randomization was performed using computer generated codes contained in opaque, sealed and sequentially numbered envelopes as well as medications prepared in identical syringes by someone not involved in the study. Recommendations were clearly stated and multiple options for treatment were provided. The recommendations are not current as the study was completed in 2008. It was unable to determine if there was a conflict of interest between the recommendation of the summary and the sponsor for any author. The evidence and setting for this study applies to many populations and settings.

A randomized double blind study by Prakash et al. (2010) (Appendix A-4) studied 60 ASA I women with singleton pregnancies scheduled for elective caesarean delivery under spinal anesthesia. Standard monitoring was applied. Each patient also received a $10 \mathrm{ml} / \mathrm{kg}$ IV infusion of Lactated Ringers solution over 15-20 min before spinal anesthesia. With participants in the left lateral position, $2 \mathrm{ml} 0.5 \%$ Hyperbaric Bupivacaine was injected intrathecally at L3-4. Oxygen $6 \mathrm{~L} / \mathrm{min}$ via face mask was given until delivery. Participants were divided into two groups: P group (phenylephrine) and E group (ephedrine). Group E received $1 \mathrm{ml}$ bolus of ephedrine $6 \mathrm{mg} / \mathrm{ml}$; group P received a $1 \mathrm{ml}$ bolus of phenylephrine $100 \mathrm{mcg} / \mathrm{ml}$. Additional boluses were administered if the systolic pressure remained at or below $80 \%$ of baseline. The incidence of nausea and vomiting, arterial and venous blood samples from a double clamped segment of the umbilical cord and Apgar scores at one, five and ten minutes were determined by the attending pediatrician and all were recorded. Descriptive statistics were calculated for 
continuous variables as mean and standard deviation and for categorical variables as frequency of distribution and percentage.

The two groups were comparable in age, weight, height, baseline hemodynamic data and dermatomal sensory levels. Apgar scores at one, five and ten minutes were comparable in the two groups with no neonate having an Apgar score $<7$ at any time. No umbilical artery $\mathrm{pH}$ was less than 7.20. Umbilical artery and venous $\mathrm{pH}$ were significantly lower in group $\mathrm{E}$ than in group $\mathrm{P}(\mathrm{p}=0.01$ and $\mathrm{P}=0.002)$. Results showed that $100 \mathrm{mcg}$ bolus doses of phenylephrine were as effective as $6 \mathrm{mg}$ bolus doses of ephedrine in the treatment of hypotension following spinal anesthesia in term parturients undergoing c-section delivery. Neonates of women treated with phenylephrine had higher umbilical cord $\mathrm{pH}$ though true fetal acidosis was not seen in any neonate.

The study by Prakash et al. (2010) was also critically appraised using the CASE worksheet (Appendix B-4). The aim of the study was clearly stated as well as the patients that the study applies to were well described. The individual authors and their affiliations were listed but credentialing was not. It was not clearly stated if the study was edited or reviewed. The inclusion and exclusion criteria were clearly stated as well as the study protocol that was followed. This study was a randomized double-blinded study making it level II evidence (Melnyk \& Fineout-Overholt, 2011). The randomization was performed by computer generated number allocation and identical syringes prepared by someone not involved with data collection were utilized. Recommendations for practice were clearly stated and multiple options for treatment were provided. The recommendations are from 2009 and therefore not current. It was unable to determine if there is a conflict of interest 
between the recommendation of the summary and the sponsor for any author. The evidence and setting for this study applies to many populations and settings.

A randomized double blind study completed by Mercier et al. (2013) (Appendix A-5) included 42 ASA I and II women with singleton pregnancies scheduled for caesarean section delivery under spinal anesthesia. Standard monitors and oxygen via nasal cannula were applied. Baseline vitals signs were obtained. Intravenous preload of $15 \mathrm{ml} / \mathrm{kg}$ Lactated Ringer's solution was given prior to spinal anesthesia of $11 \mathrm{mg}$ of hyperbaric $0.5 \%$ Bupivacaine, $2.5 \mathrm{mcg}$ Sufentanil and $0.1 \mathrm{mg}$ morphine at L2/3 or L3/4. A prophylactic vasopressor IV infusion was started at the end of spinal injection. Participants received either $2 \mathrm{mg} / \mathrm{min}$ ephedrine plus $10 \mathrm{mcg} / \mathrm{min}$ phenylephrine $(\mathrm{E}+\mathrm{P}$ group) or $2 \mathrm{mg} / \mathrm{min}$ ephedrine alone (E group). Infusions were halved, stopped or doubled based on study protocol. Groups were compared for single parametric, ordinal and nominal variables using unpaired student $t$ test, the Mann-Whitney $\mathrm{U}$ test, and Fisher exact test, respectively. Hemodynamic values over time were compared using analysis of variance for repeated measures, followed by Dunnett tests.

Participants were all comparable for demographic characteristics, gestational age, neonatal weight, upper sensory level of anesthesia, time from spinal anesthesia to incision, time from spinal anesthesia to delivery and from uterine incision to delivery, baseline SBP and maternal HR. Umbilical venous and arterial $\mathrm{pH}$ values were significantly higher in the $\mathrm{E}+\mathrm{P}$ group. The incidence of arterial $\mathrm{pH}<7.20$ was $31 \%$ higher in the $\mathrm{E}+\mathrm{P}$ group and $63 \%$ in the $\mathrm{E}$ group $(\mathrm{P}=0.09)$. However, Apgar scores at one and five minutes were similar in both groups and were never less than 7. Low venous and arterial $\mathrm{pH}$ values were associated only with the E group assignment and spinal 
anesthesia to delivery times longer than $33 \mathrm{~min}$. Compared with ephedrine alone, ephedrine plus phenylephrine infusions decreased the incidence of hypotension by approximately $50 \%$, abolished maternal tachycardia and improved venous and arterial $\mathrm{pH}$.

The CASE worksheet was applied to the study by Mercier et al. (2013) (Appendix B-5). The study met seven out of 10 criterion of the CASE worksheet. The aim of the study was clearly stated and the patients that the aim applied to were well described. The individual authors were listed along with their credentialing and affiliations. The inclusion and exclusion criteria were clearly stated and a protocol for the study was stated and followed. This study was a randomized double-blinded study therefore making it level II evidence (Melnyk \& Fineout-Overholt, 2011). The study stated that randomization was performed by using numbered, sealed, opaque envelopes ensuring both the patient and investigators were blinded to group assignment and study solutions were prepared by those not involved in the patient's care and according to the group indicated by the envelope. There was an investigator present during the study period to confirm comparability and routine procedures. The recommendations for practice were clearly stated and multiple options for treatment were provided even though the evidence was not considered current. It was unable to determine if there was a conflict of interest between the recommendation of the summary and the sponsor for any author. The evidence and setting for this study applies to many populations and settings.

Moslemi \& Rasooli (2015) (Appendix A-6) performed a randomized double blind study which included 83 healthy pregnant women with gestational age of 36 weeks or greater for elective cesarean section under spinal anesthesia. Participants were assigned to 
three different groups: phenylephrine (group $\mathrm{Ph}$ ), ephedrine (group E) and placebo (group P). Standard monitoring was applied. Prior to spinal anesthesia, all participants received a $500 \mathrm{ml}$ crystalloid bolus. Infusion of study drugs were: group $\mathrm{Ph}$ received $450 \mathrm{mcg}$ of phenylephrine in $250 \mathrm{ml}$; group E received $45 \mathrm{mg}$ of ephedrine in $250 \mathrm{ml}$; and group $\mathrm{P}$ received an infusion of only $250 \mathrm{ml}$ normal saline. The participants then received spinal anesthesia in the sitting position at L4/5 or L3/4 with $2.5 \mathrm{ml}$ of Bupivacaine $0.5 \%$ $(12.5 \mathrm{mg})$ and $2.5 \mathrm{mcg}$ of Sufentanil. After delivery and clamping of the umbilical cord, $1 \mathrm{ml}$ of blood was drawn from the umbilical artery for neonatal blood gas analysis. One minute and five minute APGAR scores were recorded as well as the umbilical artery blood gas analysis. Any decrease in BP of about $20 \%$ from baseline was treated with 50 100 mcg phenylephrine in $\mathrm{pH}$ group or 5-10 mg ephedrine in E and $\mathrm{P}$ groups. Data were analyzed using a one-way ANOVA for quantitative variables and Fishers exact probability tests and chi-square for qualitative variables and associations. Multiple comparisons were tested by post-hoc with Turkey technique. Normal distributions of data were evaluated by Kolmogorov-Smirnov normality test.

There was no significant difference in demographic data. Indications for c-section included repeated c-section $(n=53)$, other indications $(n=25)$ and patient preference $(n=4)$. Additional doses required for the treatment of hypotension was higher in groups $\mathrm{E}$ $(65.2 \%, \mathrm{n}=15)$ and $\mathrm{P}(80 \%, \mathrm{n}=20)$ than in group $\mathrm{Ph}(28.57 \%, \mathrm{n}=10)$. There was a significant difference in the 5 min APGAR scores which was better with group Ph and E rather than group $\mathrm{P}(\mathrm{P}=0.002)$. Umbilical artery (UA) blood gas analysis showed a significant difference in $\mathrm{pH}$ and $\mathrm{PCO} 2$ between $\mathrm{Ph}$ and $\mathrm{P}$ groups. Two neonates in the $\mathrm{Ph}$ group, seven in the E group and five in the $\mathrm{P}$ group had acidosis. Acidosis was 
significantly lower in phenylephrine group $(\mathrm{P}=0.043)$. Overall results showed that for women who underwent spinal anesthesia for elective c-section, SBPs and neonatal UA $\mathrm{pH}$ were best maintained with a prophylactic infusion of phenylephrine compared with those who did not receive it and were even better than those who received prophylactic ephedrine.

Finally, the study by Moslemi \& Rasooli (2015) was critically appraised using the CASE worksheet (appendix B-6). The study met eight out of 10 criterion. The aim of the study was clearly stated and the patients that the study applied to were well described. The individual authors were listed along with their credentialing and affiliation. It was not clearly stated if the study was edited or reviewed. The inclusion and exclusion criteria were clearly stated as well as the protocol used. This study was a randomized clinical trial making it level II evidence (Melnyk \& Fineout-Overholt, 2011). The study stated that randomization was performed using a table of random numbers and computer generated randomization list. Recommendations for practice were clearly stated and multiple options for treatment were provided; the recommendations were from 2015 making them current. It was unable to appropriately assess if there was a conflict of interest between the recommendation of the summary and the sponsor for any author. The evidence and setting for this study applies to many populations and settings.

\section{Cross Study Analysis}

All but one of the studies included in this systematic review were randomized control trials; the Cooper et al. (2010) study was a retrospective chart review study. Descriptive data synthesis of the included studies are illustrated in Appendix C. Key variables were identified and analyzed across the six studies. All six studies had different 
intervention groups; some included a combination of medications and some contained a placebo group. The sample size for all six studies were comparable and appropriate to determine statistical significance at the level of $\mathrm{P}<0.05$ in all the studies.

The use of oxygen supplementation was determined to be beneficial in the time preceding fetal umbilical clamping and is associated with higher maternal and fetal oxygen levels (Chatmongkolchart \& Prathep, 2013). Cooper et al. (2002) reported that they did not use supplemental oxygen at any time before delivery of the neonate, whereas Ngan Kee et al. (2008), Prakash et al. (2010) and Mercier et al. (2013) all administered supplemental oxygen to participants. Mercier et al. (2013) reported an unknown amount of oxygen administered via nasal cannula whereas both Ngan Kee et al. (2008) and Prakash et al. (2010) both reported administration of oxygen via facemask of 6-8 liters. Moslemi and Rasooli, (2015) and Copper et al. (2010) did not report on whether their participants were given any oxygen supplementation. Since this use of oxygen supplementation was demonstrated to be beneficial in other studies (Ngan Kee et al.,2008; Mercier et al. (2013), Prakash et al.,2010), results of the Cooper et al. (2002) study could have provided results of more fetal acidosis when compared to a similar study with the use of supplemental oxygenation. The Cooper et al. (2002) study did find that a lower $\mathrm{pH}$ was more frequent with ephedrine (10 out of 48 ) than with phenylephrine ( 1 out of 48 ) or combination of both groups ( 1 out of 47 ) (overall $\mathrm{P}=0.0007$ ) but puts into question that if supplemental oxygen was given, would there be as many neonates with a low $\mathrm{pH}$ in the ephedrine group?

The use of fluid prehydration before spinal administration has been demonstrated to decrease the incidence of hypotension caused from spinal anesthesia (Riley, Cohen, 
Rubenstein \& Flanagan, 1995). Cooper et al. (2002), Prakash et al. (2010), Mercier et al. (2013) and Moslemi and Rasooli (2015) all administered some sort of prehydration to their participants. Cooper et al. (2002), Prakash et al. (2010) and Mercier et al. (2013) all administered a weight-based amount of fluid, while Moslemi and Rasooli (2015) only administered a set $500 \mathrm{ml}$ boluses of prehydration to participants. Cooper et al (2010) did not report on whether any prehydration was administered. Ngan Kee et al. (2008) did not administer any hydration before spinal anesthesia but instead administered up to two liters of Lactated Ringers solution as needed after spinal anesthesia was given. Although the use of prehydration has been demonstrated to be helpful (Riley et al., 1995) it did not seem to effect the variables in question. For example, in the Ngan Kee et al. (2008) no prehydration was used and only 2 out of 102 neonates in the ephedrine group experienced acidosis versus none in the phenylephrine group.

In 1941 the American Society of Anesthesiologists (ASA) published a booklet for it's members containing the first version of a 'physical status' classification for patients about to undergo surgery (Fitz-Henry, 2011). The function of ASA classifying is to quantify the amount of physiological reserve that a patient possesses at the time of the assessment for a surgical procedure (Fitz-Henry, 2011). This may change before the patient actually undergoes the procedure, either by optimization and improvement of their physical state or because they deteriorate and have less reserve (Fitz-Henry). All of the studies but one included patients that were healthy individuals of ASA classification I or II with similar characteristics (none to mild systemic disturbances). Cooper et al. (2010) examined high risk singleton pregnant subjects with a number of different comorbidities such as prematurity, diabetes, labor problems, pregnancy induced hypertension and 
hypotension. High risk parturients have the potential for fetal complications such as fetal acidosis and therefore cannot be compared to non-high risk parturients or healthy ASA class I or II patients. For this reason, the Cooper et al. (2010) study results are not comparable to the other five studies included in this systematic review.

The spinal solution used may effect the incidence of hypotension due to where the site of action of the anesthetic tends to be (Miller \& Pardo). Hyperbaric solutions are heavier and tend to be lower within the intrathecal space and therefore may cause less sympathectomy (Miller \& Pardo). Since spinal anesthesia height is based on the concentration and solution and not the volume of anesthesia, larger volumes give higher blockade and therefore more sympathectomy leading to increased incidences of hypotension (Miller \& Pardo). Moslemi and Rasooli (2015) used $2.5 \mathrm{ml}$ of Bupivacaine $0.5 \%$ (12.5mg) with $2.5 \mathrm{mcg}$ of Sufentanil. Mercier et al. (2013) administered $11 \mathrm{mg}$ of hyperbaric $0.5 \%$ Bupivacaine, $2.5 \mathrm{mcg}$ Sufentanil and $0.1 \mathrm{mg}$ morphine. Prakash et al. (2010) administered 2ml 0.5\% Hyperbaric Bupivacaine. Ngan Kee et al. (2008) administered 2.0-2.2 $\mathrm{ml}$ of hyperbaric $0.5 \%$ bupivacaine (10-20 $\mathrm{mg}$ ) and fentanyl 15 mcg. Cooper et al. (2010) reported no detail of solutions used but did report they were not consistent. Cooper et al (2002) reportedly used four different techniques which were chosen based on preference by whomever was administering the spinal anesthetic. As described previously, local anesthetics can cause a sympathetic block, resulting in parasympathetic override. This can produce hypotension due to a decrease in venous return to the heart, a decrease in cardiac output and a decrease in systemic vascular resistance (Miller \& Pardo). The height of spinal anesthesia necessary for cesarean section delivery has the increased incidence of hypotension due to this sympathectomy. 
Copper et al. (2010) reported the incidence of hypotension to be a systolic blood pressure less than $90 \mathrm{mmHg}$ and was found to be $6.1 \%$ in the no vasopressor group $17 \%$ in the Ephedrine and 20\% in the Phenylephrine group $(\mathrm{P}=0.005)$. Cooper et al. (2002) reported that the lowest SABP recorded was higher in the P group (80\% [73-88] of baseline) than in the E group $(73 \%$ [61-87] of baseline) $(\mathrm{P}=0.02)$ but the $\mathrm{C}$ group $(77 \%$ [69-86] of baseline) was not significantly different from the $\mathrm{P}(\mathrm{P}=0.14)$ and $\mathrm{E}(\mathrm{P}=0.25)$ groups. The proportion of SABP readings below $80 \%$ of baseline was lower in the Proup $(0 \%$ [0-8]) $(\mathrm{P}+0.007)$ and in the $\mathrm{C}$ group $(4 \%[0-10])(\mathrm{P}+0.04)$ than in the $\mathrm{E}$ group $(8 \%[0-20])$, but there was no difference between the $\mathrm{P}$ and $\mathrm{C}$ groups $(\mathrm{P}=0.55)$. Ngan Kee et al. (2008) reported an overall incidence of hypotension to be 74/102 (73\%) of participants in the $\mathrm{P}$ group and 74/102 (73\%) of the E group had one or more episodes of hypotension $(\mathrm{P}=0.52)$ and required one or more boluses of vasopressor. Prakash et al. (2010) reported that the mean change in systolic pressure was comparable in the two groups with the minimum being 100 in the $\mathrm{E}$ group and 93 in the $\mathrm{P}$ group $(\mathrm{P}=0.114)$ except at 8 minutes where E group was lower $(\mathrm{P}=0.004)$. Mercier et al. (2013) reported the incidence of hypotension was halved in the $\mathrm{E}+\mathrm{P}(37 \%)$ group when compared with the $\mathrm{E}(75 \%)$ group $(\mathrm{P}=0.02)$. SBP values after onset of spinal anesthesia were not significantly different between the two groups. Moslemi, F., \& Rasooli, S. (2015) reported SBP after anesthesia every two and every five minutes were different $(\mathrm{P}>0.050)$ in the $\mathrm{Ph}$ and $\mathrm{P}$ groups. Overall, the volume of spinal anesthetic was comparable across the studies as well as the incidence of hypotension after the spinal administration and consequently does not support identifying it as a contributing factor to the outcome of fetal acidosis. 
The main focus of this systematic review was to determine if ephedrine or phenylephrine cause more or less fetal acidosis through the diversion of fetal blood flow, potentially causing more harm than good when given to woman experiencing hypotension (Nagelhout et al). . acidosis is determined through the umbilical cord blood $\mathrm{pH}$, specifically the artery. Fetal acidosis is defined as a $\mathrm{pH}$ less than 7.16 (some texts state 7.20), with adverse neonatal outcomes occurring with a pH less than 7.0 (OmoAghoja, 2014). Cooper et al. (2010) and Cooper et al. (2002) both found there was no true fetal acidosis but Cooper et al. (2002) did find that a lower $\mathrm{pH}$ was more frequent with ephedrine (10 out of 48) than with phenylephrine (1 out of 48) or combination of both groups ( 1 out of 47 ) (overall $\mathrm{P}=0.0007$ ). The ephedrine group had a lower umbilical artery $\mathrm{pH}$ than the phenylephrine group $(\mathrm{P}=0.002)$ or the combination group $(\mathrm{P}=0.009)$. Ngan Kee, et al (2008) similarly found no statistical difference between the groups they studied for fetal acidosis $(\mathrm{p}=0.70)$. However, in the ephedrine group there were two cases (out of 102 cases) with umbilical artery $\mathrm{pH}$ less than 7.0 compared with no cases in the phenylephrine group ( $\mathrm{p}=0.50$ ). Prakash et al. (2010) again found that no umbilical artery $\mathrm{pH}$ was less than 7.20 but that umbilical artery and venous $\mathrm{pH}$ were significantly lower in the ephedrine group than in the phenylephrine group $(\mathrm{p}=0.01$ and $\mathrm{P}=0.002)$ but never reached true acidosis.

Mercier et al. (2013), unlike the other studies, never used phenylephrine alone as an intervention group; instead one group was given a combination of ephedrine and phenylephrine and the other was given just ephedrine alone. They found that umbilical venous and arterial $\mathrm{pH}$ values were significantly higher in the ephedrine and phenylephrine combination group (average $=7.24)$ than in the ephedrine alone group 
(average $=7.19)(\mathrm{P}=0.05)$. The incidence of arterial $\mathrm{pH}<7.20$ was $31 \%$ in the ephedrine and phenylephrine combination group and $63 \%$ in the ephedrine alone group $(\mathrm{P}=0.09)$. Interestingly, Moslemi and Rasooli (2015) used three different intervention groups: phenylephrine alone; ephedrine alone; and a placebo group that received no medication. Umbilical artery blood gas analysis showed a significant difference in $\mathrm{pH}$. Two neonates out of 30 in the phenylephrine group, seven out of 27 in the ephedrine group and five out of 26 in the placebo group had acidosis. Acidosis was significantly lower in phenylephrine group $(\mathrm{P}=0.043)$.

Overall, out of all groups included in the different studies, the phenylephrine group alone provided a higher $\mathrm{pH}$ than any other group alone or in combination but the incidence of true fetal acidosis of a pH less than 7.16 (or 7.20) was extremely low and thus insignificant. In all six studies, Apgar scores at one and five min were similar and there were no statistically significant findings except for Moslemi and Rasooli (2015) who found that there was a significant difference in the 5 min APGAR scores which was better in the phenylephrine and ephedrine groups rather than the placebo group $(\mathrm{P}=0.002)$. These findings suggest that the Apgar score does not depict neonatal outcome. Incidentally, nausea and vomiting were frequently studied. Nausea and vomiting is a side effect of hypotension but the correlation of nausea and vomiting specific to ephedrine or phenylephrine had not been studied. Cooper et al. (2002) and Ngan Kee et al. (2008) both examined nausea and vomiting in the intervention groups and both found that there was more nausea and vomiting in the ephedrine groups. Cooper et al. (2002) found that there was no change in the phenylephrine group from baseline nausea and vomiting $(\mathrm{P}=0.30)$ but in the ephedrine and combination of phenylephrine and ephedrine 
group the nausea and vomiting increased from baseline $(\mathrm{E}=\mathrm{P}<0.0001)(\mathrm{C}=\mathrm{P}=0.007)$. There was no significant different between the ephedrine and combination groups $(\mathrm{P}=0.09)$. In the $\mathrm{E}$ group vomiting (18 out of 48$)$ was associated with decreased heart rate and systolic blood pressure and increased ephedrine doses.

Next, the summary and conclusions will be presented. 


\section{Summary and Conclusions}

Hypotension during cesarean section delivery can have detrimental effects on both the mother and the neonate (Lee et al., 2002). These effects include decreased uteroplacental blood flow, impaired fetal oxygenation with asphyxial stress and fetal acidosis (Lee et al.). Some vasoactive medications have been found to be detrimental to the neonate and divert fetal blood flow, potentially causing more harm than good in pregnant women (Nagelhout et al., 2013). Studies have shown that ephedrine can cause fetal acidosis as a side effect and more so than phenylephrine; concerns about the adverse effects of phenylephrine on uterine blood flow have also been reported. Ephedrine is a mixed acting adrenergic receptor agonist that has both alpha and beta agonist properties. Ephedrine's predominant beta effect causes an increase in arterial pressure by increasing cardiac output rather than by vasoconstriction. Phenylephrine is a pure alpha-adrenergic agonist which increases the blood pressure through peripheral vasoconstriction (Nagelhout et al.). A literature review of vasoactive drugs conducted on animals varied in terms of the safety and efficacy of the two drugs. The results may not apply to the human populations and may not be appropriate because of the species differences (Lee et al., 2002).

This systematic review compared these two drugs and their efficacy on fetal and maternal outcomes, specifically examining fetal acidosis through umbilical artery $\mathrm{pH}$ testing. Outcomes assessed were maternal hypotension, spinal anesthetic used, supplemental oxygenation, intravenous prehydration, ASA classification and Apgar score. The Preferred Reporting Items for Systematic Reviews and Meta-Analyses (PRISMA) flowchart assisted in identifying appropriate research by providing a step-by- 
step approach with instructions related to those to be included as well as those to exclude (Moher et al., 2009). Each included study was then illustrated in a table in order to identify key variables being researched. The studies were then critically appraised using the CASE worksheet (Foster \& Shurtz, 2013). Finally, a cross study analysis was done to examine key outcomes across the studied variables.

No direct conclusion can be drawn from any of the specific variables and their effect on fetal acidosis mainly due to the differences in study design (oxygen supplementation; ASA classification; IV fluid prehydration; hypotension incidence after spinal anesthesia; spinal solution and technique; umbilical artery $\mathrm{pH}$; Apgar scores; nausea and vomiting during the case).

Related to oxygen supplementation, some of the studies reported the use of oxygen supplementation whereas some did not report on the use while others reported no use. Since the use of oxygen supplementation was demonstrated to be beneficial in three studies, (Ngan Kee et al. [2008], Prakash et al. [2010] and Mercier et al. [2013]), studies where no supplemental oxygen was used could have potentially resulted in more fetal acidosis when compared to a similar study with the use of supplemental oxygenation.

High risk parturients have the potential for fetal complications such as fetal acidosis and therefore cannot be compared to non-high risk parturients or healthy ASA class I or II patients. For this reason, results of the Cooper et al. (2010) study, which included all high risk parturients, are not comparable to the other five studies included in this systematic review due to the high risk nature of the patients included.

Cooper et al. (2002), Prakash et al. (2010), Mercier et al. (2013) and Moslemi and Rasooli (2015) all administered some sort of prehydration to their participants. Cooper et 
al. (2010) did not report on whether any prehydration was administered. Ngan Kee et al. (2008) did not administer any hydration before spinal anesthesia but instead administered up to two liters of Lactated Ringers solution as needed after spinal anesthesia was given. The late use of IV hydration or none use could have contributed to hypotension experienced during spinal anesthesia.

Overall, the volume of spinal anesthetic was comparable across the studies as well as the incidence of hypotension after the spinal administration. Consequently, this does not support identifying it as a contributing factor to the outcome of fetal acidosis.

In examining umbilical artery $\mathrm{pH}$, Cooper et al. (2002), Cooper et al. (2010), Ngan Kee, et al. (2008), Moslemi and Rasooli (2015), and Prakash et al. (2010) found that no umbilical artery $\mathrm{pH}<7.20$; however, umbilical artery and venous $\mathrm{pH}$ were significantly lower in the ephedrine group than in the phenylephrine group but never reached true acidosis. In contrast, Mercier et al. (2013) used a different study design and found that umbilical venous and arterial $\mathrm{pH}$ values were significantly higher in the ephedrine and phenylephrine combination group (average $=7.24)$ than in the ephedrine alone group (average $=7.19)(\mathrm{P}=0.05)$.

In all six studies, Apgar scores at one and five min were similar and there were no statistically significant findings except for Moslemi and Rasooli (2015). These researchers found that there was a significant difference in the 5 min APGAR scores, which were better in the phenylephrine and ephedrine groups as compared to the placebo group $(\mathrm{P}=0.002)$.

There was no difference between the two vasopressors in the incidence of true fetal acidosis but it is clear that the use of phenylephrine was associated with a better fetal 
umbilical artery $\mathrm{pH}$ than in those women given ephedrine. Two of the studies included in this systematic review included nausea and vomiting as a variable and found that there was an increased incidence of nausea and vomiting with the administration of ephedrine. Incidentally, Cooper et al. (2002) and Ngan Kee et al. (2008) both examined nausea and vomiting in the intervention groups. Both authors found that there was more nausea and vomiting in the ephedrine groups.

Limitations associated with this systematic review included that not all studies reported on the use of oxygen supplementation in their participants. The dosages, medications used and groups within the studies all varied across the studies, making comparisons difficult. The sample sizes of some of the studies were small and the participants included in five out of the six studies were all healthy women undergoing elective c-section delivery, so extrapolation to situations where fetal compromise is present or to emergency C-section delivery is challenging. The use of IV prehydration may effect the incidence of hypotension and since some studies reported they did use it and some did not, it is difficult to make comparisons across them.

In summary, this systematic review supports the cautioned use of ephedrine over phenylephrine in the obstetric patient experiencing maternal hypotension during spinal anesthesia for elective cesarean section delivery, despite limitations. The use of phenylephrine was associated with better fetal $\mathrm{pH}$ status than ephedrine.

Recommendations and implications for advanced nursing practice will be discussed in the next section. 


\section{Recommendations and Implications for Advanced Nursing Practice}

Systematic reviews provide a succinct review and critical analysis of existing research studies regarding the same subject matter and can therefore offer key information for evidence based practice. Certified Registered Nurse Anesthetists aim to provide the safest care to all their patients and in doing so they rely on current evidencebased knowledge found through thorough research to guide their practice. The incidence of hypotension after spinal anesthesia can not always be prevented but the vasopressor used for treatment can be chosen using critical thinking and evidence-based knowledge found through research.

Although the occurrence of true fetal acidosis could not be determined with the use of either ephedrine or phenylephrine in the reviewed studies, the incidence of a higher $\mathrm{pH}$ with phenylephrine should be taken in to consideration when choosing the best vasopressor. Both ephedrine and phenylephrine groups had similar efficacy for preventing or treating hypotension and there was no difference in clinical neonatal outcome as measured by Apgar scores. Nevertheless, the objective of obstetric anesthesia practice is to deliver the fetus in the best condition possible. The studies included reported on the higher incidence of a lower normal $\mathrm{pH}$ with ephedrine. Caution should also be taken with the use of ephedrine as the sole vasopressor of choice in obstetric anesthesia and particularly in cases where there is an already increased risk of fetal acidosis.

Continuing education on the indications, dosages and side effects of both phenylephrine and ephedrine should be obtained prior to their use. No vasopressor alone shows benefit over the other but caution should be used based on their side effects. 
Ephedrine results in lower $\mathrm{pH}$ values but true acidosis has not been seen and phenylephrine's primary alpha agonist properties promote it's side effect of bradycardia. Due to this, patients experiencing bradycardia should not be given phenylephrine as a vasopressor because of the risk of worsening bradycardia. Based on the incidental finding of nausea and vomiting associated with ephedrine use, caution should be taken with the use of ephedrine in patients at high risk for nausea and vomiting or those already experiencing such. Systematic reviews are intended to provide up to date information regarding the latest, safest and most effective methods of anesthesia care. This information can be used not only to improve the practice of existing practitioners, but also become incorporated in the curriculum of institutions training future CRNAs.

No recommendations on policy change can be made when it comes to the use of ephedrine and phenylephrine in choosing one over the other. Based on the conclusion of this systematic review, both medications are acceptable for use in practice. Caution should be taken with the use of ephedrine due to the outcome of lower normal $\mathrm{pH}$ than phenylephrine, especially in patients with risk of fetal acidosis.

Further randomized controlled trials need to be conducted with larger sample sizes and and including key variables aforementioned.. Through this research, practitioners may be able to better gauge the use of ephedrine and phenylephrine in their everyday practice. A separate study on the incidence of ephedrine-induced post-operative nausea and vomiting should be completed to determine its role in the matter. These studies would be essential in developing even safer and more effective protocols in obstetric anesthesia. 


\section{References}

Altman, D., Clarke, M., Devereaux, P., Gotzsche, P., Ioannidis, J. P., Kleijnen, J., ... Mulrow, C. (2009). The PRISMA statement for reporting systematic reviews and meta-analysis of studies that evaluate health care interventions: Explanation and elaboration. PLoS Medicine, 6(7), 1-28.

American Academy of Pediatrics. (2015). The apgar score. Pediatrics, 136(4), 819-822.

Chatmongkolchart, S. \& Prathep, S. (2013). Supplemental oxygen for caesarean section during regional anesthesia. Cochrane Database of Systematic Reviews, 6. Retrieved from http://onlinelibrary.wiley.com/doi/10.1002/14651858.CD006161.pub2/full

Cooper, D. W., Carpenter, M., Mowbray, P., Desira, W. R., Ryall, D. M., \& Kokri, M. S. (2002). Fetal and maternal effects of phenylephrine and ephedrine during spinal anesthesia for cesarean delivery. The Journal of the American Society of Anesthesiologists, 97(6), 1582-1590.

Cooper, D. W., Sharma, S., Orakkan, P., \& Gurung, S. (2010). Retrospective study of association between choice of vasopressor given during spinal anesthesia for high-risk caesarean delivery and fetal $\mathrm{pH}$. International Journal of Obstetric Anesthesia, 19(1), 44-49.

Evans, D. (2002). Systematic review of interpretive research: Interpretive data synthesis of processed data. Australian Journal of Advanced Nursing, 20 (2), 22-26.

Fineout-Overholt, E., Melnyk, B. M., Stillwell, S. B., \& Williamson, K. M. (2010). Evidence-based practice step by step: Critical appraisal of the evidence: Part I. The American Journal of Nursing, 110(7), 47-52.

Fitz-Henry, J. (2011). The ASA classification and peri-operative risk. The Annals of The 
Royal College of Surgeons of England, 93(3), 185-187.

Foster, M. J. \& Shurtz, S. (2013, July). Making the critical appraisal for summaries of evidence (CASE) for evidence-based medicine (EBM): Critical appraisal of summaries of evidence. Journal of the Medical Library Association, 101, 192198.

Gunda, C. P., Malinowski, J., Tegginmath, A., Suryanarayana, V. G., \& Chandra, S. B. (2010). Vasopressor choice for hypotension in elective cesarean section: Ephedrine or phenylephrine? Arch Med Sci, 6(2), 257-63.

Huch, A., Huch, R., \& Rooth, G. (1994). Guidelines for blood sampling and measurement of $\mathrm{pH}$ and blood gas values in obstetrics: Based upon a workshop held in Zurich, Switzerland, March 19, 1993, by an ad hoc committee. European Journal of Obstetrics \& Gynecology and Reproductive Biology, 54(3), 165-175.

Kang, Y. G., Abouleish, E., \& Caritis, S. (1982). Prophylactic intravenous ephedrine infusion during spinal anesthesia for cesarean section. Anesthesia \& Analgesia, 61(10), 839-842.

Kee, W. D. N., Khaw, K. S., Tan, P. E., Ng, F. F., \& Karmakar, M. K. (2009). Placental transfer and fetal metabolic effects of phenylephrine and ephedrine during spinal anesthesia for cesarean delivery. The Journal of the American Society of Anesthesiologists, 111(3), 506-512.

Lee, A., Kee, W. D. N., \& Gin, T. (2002). A quantitative, systematic review of randomized controlled trials of ephedrine versus phenylephrine for the management of hypotension during spinal anesthesia for cesarean delivery. Anesthesia \& Analgesia, 94(4), 920-926. 
Liberati, A., Altman, D. G., Tetzlaff, J., Mulrow, C., Gotzsche, P. C., Ioannidis, J. P., \& Moher, D. (2009). The PRISMA statement for reporting systematic reviews and meta-analyses of studies that evaluate health care interventions: Explanation and elaboration. Annals of internal medicine, 151(4), W-65.

McGrath, J. M., Chestnut, D. H., Vincent, R. D., DeBruyn, C. S., Atkins, B. L., Poduska, D. J., \& Chatterjee, P. (1994). Ephedrine remains the vasopressor of choice for treatment of hypotension during ritodrine infusion and epidural anesthesia. Anesthesiology, 80(5), 1073-81.

Melnyk, B. M., \& Fineout-Overholt, E. (2011). Evidence-based practice in nursing \& healthcare: A guide to best practice. Philadelphia, PA: Lippincott Williams \& Wilkins.

Mercier, F. J., Augè, M., Hoffmann, C., Fischer, C., \& Le Gouez, A. (2013). Maternal hypotension during spinal anesthesia for caesarean delivery. Minerva Anestesiol, $79(1), 62-73$.

Miller, R. D., \& Pardo, M. (2011). Basics of anesthesia. St. Louis, MO: Elsevier Health Sciences.

Moher, D., Liberati, A., Tetzlaff, J., \& Altman, D. G. (2009). Preferred reporting items for systematic reviews and meta-analyses: The PRISMA statement. Annals of internal medicine, 151(4), 264-269.

Moher, D., Shamseer, L., Clarke, M., Ghersi, D., Liberati, A., Petticrew, M., Shekelle, P. \& Stewart, L. A. (2015). Preferred reporting items for systematic review and meta-analysis protocols (PRISMA-P) 2015 statement. Systematic reviews, 4(1), 1.

Morgan, P. (1994). The role of vasopressors in the management of hypotension induced 
by spinal and epidural anesthesia. Canadian Journal of Anaesthesia, 41(5), 404413.

Moslemi, F. \& Rasooli, S. (2015). Comparison of prophylactic infusion of phenylephrine with ephedrine for prevention of hypotension in elective cesarean section under spinal anesthesia: a randomized clinical trial. Iranian Journal of Medical Sciences, 40(1), 19.

Nagelhout, J. J., Elisha, S., \& Plaus, K. (2013). Nurse anesthesia. St. Louis, MO: Elsevier Health Sciences.

Ngan Kee, W. D., Khaw, K. S., Lau, T. K., Ng, F. F., Chui, K., \& Ng, K. L. (2008). Randomized double-blinded comparison of phenylephrine vs. ephedrine for maintaining blood pressure during spinal anesthesia for the non-elective Caesarean section. Anesthesia, 63(12), 1319-1326.

Omo-Aghoja, L. (2014). Maternal and fetal Acid-base chemistry: A major determinant of perinatal outcome. Annals of medical and health sciences research, 4(1), 8-17.

Prakash, S., Pramanik, V., Chellani, H., Salhan, S., \& Gogia, A. R. (2010). Maternal and neonatal effects of bolus administration of ephedrine and phenylephrine during spinal anesthesia for caesarean delivery: a randomized study. International Journal of Obstetric Anesthesia, 19(1), 24-30.

Ralston, D. H., \& Shnider, S. M. (1974). Effects of equipotent ephedrine, metaraminol, mephentermine, and methoxamine on uterine blood flow in the pregnant ewe. The Journal of the American Society of Anesthesiologists, 40(4), 354-370.

Riley, E. T., Cohen, S. E., Rubenstein, A. J., \& Flanagan, B. (1995). Prevention of hypotension after spinal anesthesia for cesarean section: six percent hetastarch 
versus lactated Ringer's solution. Anesthesia \& Analgesia, 81(4), 838-842.

Suresh, M.S., Segal, B. S., Preston, R. L., Fernando, R., \& Mason, C. L. (2012). Shnider and Levinson's anesthesia for obstetrics. Philadelphia, PA: Lippincott Williams \& Wilkins.

Taylor, J. C., \& Tunstall, M. E. (1991). Dosage of phenylephrine in spinal anesthesia for caesarean section. Anaesthesia, 46(4), 314-316.

United States. Centers for Disease Control and Prevention (2015). Births in the United States, 2015 [Data File]. Retrieved from: https://www.cdc.gov/nchs/products/databriefs/db258.htm 
Data Collection Tool

\section{Appendix A-1}

Cooper, D. W., Sharma, S., Orakkan, P., \& Gurung, S. (2010). Retrospective study of association between choice of vasopressor given during spinal anesthesia for high-risk caesarean delivery and fetal pH. International Journal of Obstetric Anesthesia, 19(1), 44-49.

\begin{tabular}{|c|c|c|c|c|c|}
\hline $\begin{array}{c}\text { Method/Level } \\
\text { of evidence \& } \\
\text { Major } \\
\text { Variables } \\
\text { Studied }\end{array}$ & Sample/ Setting & Intervention & Data Analysis & Results & Limitations \\
\hline $\begin{array}{l}\text { Retrospective } \\
\text { observational } \\
\text { study and } \\
\text { chart review } \\
\text { over a 4-year } \\
\text { period from } \\
2000-2003\end{array}$ & $\begin{array}{l}\text { Charts reviewed } \\
\text { were those in } \\
\text { the 4-year } \\
\text { period of } 2000 \text { - } \\
\text { 2003, women } \\
\text { with high risk } \\
\text { pregnancies that } \\
\text { had a cesarean } \\
\text { section under } \\
\text { spinal } \\
\text { anesthesia for } \\
\text { singleton } \\
\text { delivery where } \\
\text { fetal umbilical } \\
\text { artery and } \\
\text { venous pH were } \\
\text { recorded and } \\
\text { these } \\
\text { participants } \\
\text { either received } \\
\text { ephedrine }\end{array}$ & $\begin{array}{l}\text { Once women for the study } \\
\text { were identified, the authors } \\
\text { then reviewed the notes, } \\
\text { recording maternal and } \\
\text { fetal demographic and } \\
\text { operative data. Blood gas } \\
\text { values, taken from a } \\
\text { double clamped segment of } \\
\text { umbilical cord at delivery, } \\
5 \text { min Apgar scores } \\
\text { assessed by a midwife and } \\
\text { admission to the neonatal } \\
\text { unit were all recorded. } \\
\text { During the period of the } \\
\text { study, ephedrine was } \\
\text { routinely given as } 6 m g \\
\text { boluses and phenylephrine } \\
\text { as } 100 \text { mcg boluses, at the } \\
\text { discretion of the } \\
\text { anesthetist. Phenylephrine } \\
\text { infusion was recommended }\end{array}$ & $\begin{array}{l}\text { Primary outcome was } \\
\text { umbilical artery pH. } 112 \\
\text { participants per group } \\
\text { would give the study an } \\
80 \% \text { chance of detecting a } \\
0.03 \text { difference in umbilical } \\
\text { artery pH, at } \mathrm{P}=0.05 \text { based } \\
\text { on a standard deviation of } \\
0.08 \text { for umbilical artery } \mathrm{pH} \\
\text { for non-elective C-section } \\
\text { under spinal anesthesia. } \\
\text { Secondary outcomes were } \\
\text { the incidence of fetal } \\
\text { acidosis (pH }<7.20), \text { low } 5 \\
\text { min Apgar score ( }<7 \text { ) and } \\
\text { admission to the neonatal } \\
\text { unit. Mann-Whitney and } \\
\text { Kruskal-Wallis tests were } \\
\text { used for direct comparison }\end{array}$ & $\begin{array}{l}\text { The no vasopressor, ephedrine } \\
\text { and phenylephrine groups were } \\
\text { similar for demographic data but } \\
\text { there were differences for } \\
\text { diabetes ( } \mathrm{P}=0.042 \text { ), previous } \mathrm{C} \text { - } \\
\text { section ( } \mathrm{p}=0.19 \text { ), pregnancy } \\
\text { induced hypertension ( } \mathrm{P}=0.003 \text { ), } \\
\text { spinal local anesthetic dose } \\
(\mathrm{P}=0.006) \text { and hypotension } \\
\text { ( } \mathrm{P}=0.005 \text { ). The median total dose } \\
\text { of ephedrine given before } \\
\text { delivery was } 12 \mathrm{mg} \text {; the median } \\
\text { total dose of phenylephrine in } \\
\text { given before delivery was } 200 \\
\text { mcg. The authors were unable to } \\
\text { find accurate records of the dose } \\
\text { of vasopressor given by infusion. } \\
13 \% \text { of the ephedrine group were } \\
\text { given a second line vasopressor } \\
\text { (median total dose } 200 \text { mcg) } \\
\text { compared with } 5 \% \text { of the }\end{array}$ & $\begin{array}{l}\text { Low doses of } \\
\text { ephedrine used, } \\
\text { cofounding variables } \\
\text { were not examined. } \\
\text { Prematurity and labor } \\
\text { may have contributed } \\
\text { to the lack of } \\
\text { difference between the } \\
\text { vasopressor groups in } \\
\text { this high risk study by } \\
\text { reducing hypotension } \\
\text { and therefore, } \\
\text { vasopressor } \\
\text { requirements. Urgent } \\
\text { nature of the surgery } \\
\text { for many of the high } \\
\text { risk cases may also } \\
\text { have reduced the } \\
\text { difference between the } \\
\text { groups by reducing the } \\
\text { spinal delivery interval. }\end{array}$ \\
\hline
\end{tabular}




\begin{tabular}{|c|c|c|c|c|c|}
\hline $\begin{array}{l}\text { artery and } \\
\text { venous } \mathrm{pH} \\
\text { values }\end{array}$ & $\begin{array}{l}\text { boluses, } \\
\text { ephedrine } \\
\text { infusion, } \\
\text { phenylephrine } \\
\text { bolus or } \\
\text { phenylephrine } \\
\text { infusion for low } \\
\text { blood pressures } \\
\\
\text { No vasopressor } \\
\mathrm{n}=115 \\
\text { Ephedrine total } \\
\mathrm{n}=122 \\
\text { (Ephedrine } \\
\text { bolus } \mathrm{n}=110 \\
\text { Ephedrine } \\
\text { infusion } \mathrm{n}=12 \text { ) } \\
\text { Phenylephrine } \\
\text { total } \mathrm{n}=148 \\
\text { (Phenylephrine } \\
\text { bolus } \mathrm{n}=51 \\
\text { Phenylephrine } \\
\text { infusion } \mathrm{n}=97 \text { ) }\end{array}$ & $\begin{array}{l}\text { only to be given according } \\
\text { to a standard protocol, } \\
\text { which had been developed } \\
\text { for a prospective study } \\
\text { completed in } 2001 \text { at our } \\
\text { hospital. Phenylephrine } \\
\text { was started at } 33 \mathrm{mcg} / \mathrm{min} \\
\text { immediately following } \\
\text { spinal injection and then } \\
\text { titrated aiming to keep } \\
\text { systolic blood pressure } \\
\text { (SBP) at baseline. The } \\
\text { infusion rate was doubled } \\
\text { or halved as required. The } \\
\text { Max infusion rate was } 67 \\
\text { mcg/min. If there was } \\
\text { hypotension despite the } \\
\text { prophylactic infusion, } 100 \\
\text { mcg boluses of } \\
\text { phenylephrine were given. } \\
\text { There were no guidelines } \\
\text { for ephedrine infusion. } \\
\text { Criteria for admission to } \\
\text { the neonatal unit were } \\
\text { gestation }<34 \text { weeks, } \\
\text { weight }<1800 \text { g or poor } \\
\text { condition. }\end{array}$ & $\begin{array}{l}\text { of the groups and } \\
\text { subgroups. } \\
\text { Forward stepwise multiple } \\
\text { regression analysis was used } \\
\text { to find which independent } \\
\text { variables were associated } \\
\text { with umbilical artery pH. } \\
\text { The potential explanatory } \\
\text { variables entered into the } \\
\text { multiple regression analysis } \\
\text { were choice of vasopressor, } \\
\text { method of administration, } \\
\text { time period, maternal age, } \\
\text { maternal height, maternal } \\
\text { weight, gestational age, fetal } \\
\text { weight, previous C-section, } \\
\text { spinal dose, spinal delivery } \\
\text { interval, hypotension, direct } \\
\text { involvement of a consultant } \\
\text { obstetrician. Data were } \\
\text { analyzed using SPSS } \\
\text { version } 12 . \mathrm{P}=<0.05 \text { was } \\
\text { regarded as statistically } \\
\text { significant }\end{array}$ & $\begin{array}{l}\text { phenylephrine group (all } \\
\text { ephedrine boluses, median total } \\
\text { dose } 9 \mathrm{mg} \text { ) ( } \mathrm{P}=0.014) \text {. There was } \\
\text { no difference in umbilical artery } \\
\text { pH between the three groups on } \\
\text { direct comparison ( } \mathrm{P}=0.21) \text {. } \\
\text { Following forward stepwise } \\
\text { multiple regression analysis, the } \\
\text { only variable that was associated } \\
\text { with altered pH was non- } \\
\text { reassuring fetal heart rate trace } \\
\text { ( } \mathrm{P}=0.71) . \text { On direct comparison } \\
\text { there was no difference in the } \\
\text { incidence of umbilical artery } \mathrm{pH} \\
<7.20 \text { ( } \mathrm{P}=0.21) \text {, or } 5 \text { min Apgar } \\
\text { score }<7(0.089) \text {, between the } \\
\text { groups, but there was a } \\
\text { difference in the incidence of } \\
\text { admissions to the neonatal unit } \\
(0.040), 37 \% \text { of patients in the } \\
\text { phenylephrine group were } \\
\text { admitted, } 23 \% \text { in ephedrine } \\
\text { group and } 33 \% \text { in no vasopressor } \\
\text { group. The authors observations } \\
\text { for umbilical artery pH differ } \\
\text { from those in low risk } \\
\text { participants which show a higher } \\
\text { pH with phenylephrine. }\end{array}$ & $\begin{array}{l}\text { There was no accurate } \\
\text { record of maternal } \\
\text { oxygen administration } \\
\text { which can affect } \\
\text { umbilical venous PO2. } \\
\text { The ephedrine and } \\
\text { phenylephrine groups } \\
\text { were not matched for } \\
\text { potential confounding } \\
\text { variables such as time } \\
\text { period of operation, } \\
\text { method of vasopressor } \\
\text { administration, labor, } \\
\text { and bupivacaine dose. } \\
\text { This could have biased } \\
\text { the univariate analysis. } \\
\text { Arterial pressure was } \\
\text { documented by hand so } \\
\text { there may have been a } \\
\text { degree of selective } \\
\text { recording or rounding } \\
\text { up of readings. }\end{array}$ \\
\hline
\end{tabular}


Cooper, D. W., Carpenter, M., Mowbray, P., Desira, W. R., Ryall, D. M., \& Kokri, M. S. (2002). Fetal and maternal effects of phenylephrine and ephedrine during spinal anesthesia for cesarean delivery. The Journal of the American Society of Anesthesiologists, 97(6), 1582-1590.

\begin{tabular}{|c|c|c|c|c|c|}
\hline $\begin{array}{c}\text { Method/lev } \\
\text { el of } \\
\text { evidence \& } \\
\text { Major } \\
\text { variables } \\
\text { studied } \\
\end{array}$ & $\begin{array}{c}\text { Sample/ } \\
\text { Setting }\end{array}$ & Intervention & Data Analysis & Results & Limitations \\
\hline $\begin{array}{l}\text { Randomized } \\
\text { /Double } \\
\text { blind study } \\
\text { Level II } \\
\text { evidence } \\
\text { Maternal: } \\
\text { blood } \\
\text { pressure and } \\
\text { heart rate, } \\
\text { Nausea and } \\
\text { vomiting } \\
\text { scores. } \\
\text { Fetal: Apgar } \\
\text { score, } \\
\text { umbilical } \\
\text { artery pH } \\
\text { and venous } \\
\text { pH }\end{array}$ & $\begin{array}{l}\text { Inclusion: } \\
\text { ASA I and II } \\
\text { participants } \\
\text { scheduled } \\
\text { for elective } \\
\text { C-section } \\
\text { under spinal } \\
\text { anesthesia. } \\
\text { Singleton } \\
\text { pregnancies, } \\
\text { with no fetal } \\
\text { abnormalitie } \\
\text { s and no } \\
\text { history of } \\
\text { preeclampsi } \\
\text { a or diabetes } \\
\text { mellitus. } \\
\text { Exclusion: } \\
\text { ASA >III, } \\
\text { non elective } \\
\text { C-sections, } \\
\text { C-sections } \\
\text { requiring }\end{array}$ & $\begin{array}{l}\text { Before entering the anesthesia room, the } \\
\text { participants had } 3 \text { blood pressure and heart } \\
\text { rate readings recorded with an automated } \\
\text { oscillometer at } 3 \text { min intervals while sitting } \\
\text { in bed. The lowest of the } 3 \text { readings was } \\
\text { recorded as the baseline values. The highest } \\
\text { nausea and vomiting score was recorded for } \\
30 \text { min before the spinal ( } 0=\text { none, } 1=\text { nausea } \\
\text { with no vomiting, } 2=\text { vomiting). participants } \\
\text { were randomly allocated by envelope } \\
\text { selection to one of } 3 \text { vasopressor solutions to } \\
\text { maintain maternal systolic arterial pressure. } \\
\text { The participants, anesthetists, nurses and } \\
\text { midwives involved were all blinded to the } \\
\text { patient grouping. The P group received } \\
\text { phenylephrine } 100 \text { mcg/ml. the E group } \\
\text { received ephedrine } 3 \text { mg/ml and the C group } \\
\text { received a combination of phenylephrine } \\
50 \mathrm{mcg} / \mathrm{ml} \text { combined with ephedrine } \\
1.5 \mathrm{mg} / \mathrm{ml} \text {. These concentrations were based } \\
\text { on unpublished pilot work performed at the } \\
\text { hospital where the study took place to find } \\
\text { solutions of similar potency. A third party not } \\
\text { involved with the study opened an envelop }\end{array}$ & $\begin{array}{l}\text { The study was } \\
\text { designed to } \\
\text { have an } 80 \% \\
\text { chance of } \\
\text { detecting a } 15 \% \\
\text { incidence of } \\
\text { fetal acidosis } \\
\text { (umbilical } \\
\text { artery pH } \\
<7.20 \text { ) in the } \\
\text { ephedrine } \\
\text { group (E } \\
\text { Group) and an } \\
80 \% \text { chance of } \\
\text { detecting a } \\
\text { difference of } \\
0.03 \text { in the } \\
\text { mean umbilical } \\
\text { artery pH at } \\
\text { P=0.05. The } \\
\text { Kruskal-Wallis } \\
\text { test was used to } \\
\text { compare the } \\
\text { three groups. If }\end{array}$ & $\begin{array}{l}48(\mathrm{n}=48) \text { participants in the phenylephrine } \\
\text { group ( } \mathrm{P} \text { group), } 50(\mathrm{n}=50) \text { in the ephedrine } \\
\text { group (E Group) and } 49(\mathrm{n}=49) \text { in } \\
\text { combination of phenylephrine and } \\
\text { ephedrine solution group ( } \mathrm{C} \text { group) were } \\
\text { studied. The } 3 \text { groups were comparable for } \\
\text { age, height, weight, gestation, breech } \\
\text { presentation, previous c-section, delivery } \\
\text { and birth weight. The groups were well } \\
\text { matched for the spinal anesthetics given ( } \mathrm{P}= \\
0.99) \text {, the investigators collecting data } \\
\text { ( } \mathrm{P}=0.77) \text { and for the uterine incision to } \\
\text { delivery interval ( } \mathrm{P}=0.10) \text {. } \\
\text { Overall the mean systolic arterial blood } \\
\text { pressure (SABP) from spinal until delivery } \\
\text { was similar for all three groups as was the } \\
\text { SABP over time for the } 3 \text { groups. There was } \\
\text { a small but statistically significant } \\
\text { difference between } 20 \text { and } 25 \text { min post- } \\
\text { spinal when the MAP was lower in the } \\
\text { phenylephrine group than in the epidural } \\
\text { and combination groups. The incidence of } \\
\text { hypotension (SABP }<80 \%) \text { was similar for } \\
\text { the } 3 \text { groups. However, there was a small }\end{array}$ & $\begin{array}{l}\text { Code had to } \\
\text { be broken in } \\
\text { two of the } \\
\text { ephedrine } \\
\text { cases due to } \\
\text { hypotension } \\
\text { not } \\
\text { responding } \\
\text { to } \\
\text { ephedrine. } \\
\text { All } \\
\text { participants } \\
\text { were healthy } \\
\text { women } \\
\text { undergoing } \\
\text { elective C- } \\
\text { section } \\
\text { delivery so } \\
\text { extrapolatio } \\
\text { n to } \\
\text { situations } \\
\text { where fetal } \\
\text { compromise } \\
\text { is present or }\end{array}$ \\
\hline
\end{tabular}




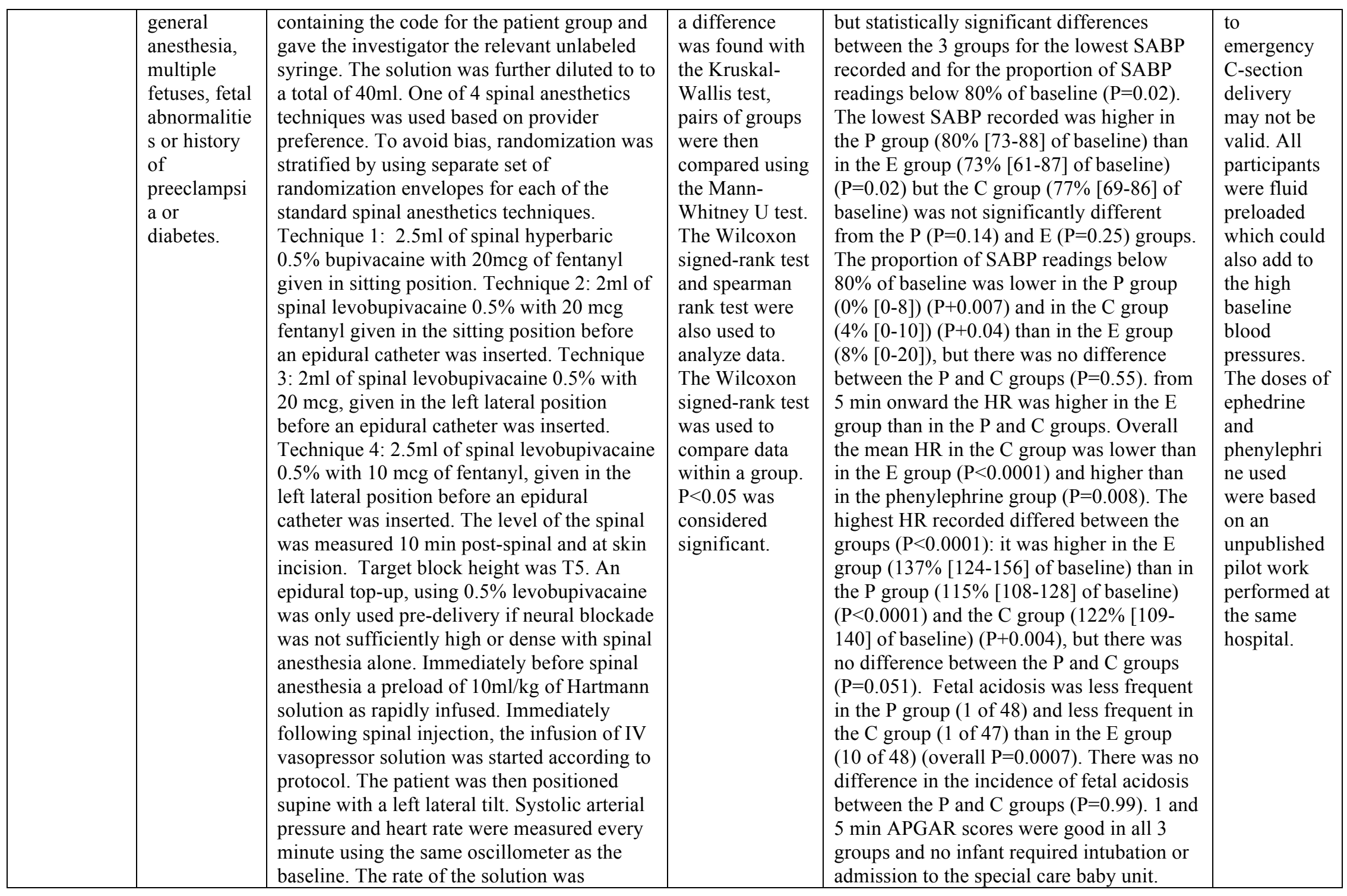




\begin{tabular}{|c|c|c|c|}
\hline & & $\begin{array}{l}\text { doubled or halved if the systolic arterial } \\
\text { blood pressure (BP) fell below or above } 0.75 \\
\text { times the baseline. Phenylephrine was started } \\
\text { at } 33 \mathrm{mcg} / \mathrm{min} \text {; ephedrine was started at } \\
1 \mathrm{mg} / \mathrm{min} \text { or half the dose rate for each for the } \\
\text { combination solution. The max infusion rate } \\
\text { was } 40 \mathrm{ml} / \mathrm{hr} \text {. and min rate was } 1.3 \mathrm{ml} / \mathrm{hr} \text {. If } \\
\text { more than } 40 \mathrm{ml} / \mathrm{hr} \text {. was required } 1 \text { or } 2 \mathrm{ml} \\
\text { boluses of trial solution could be given. If the } \\
\text { systolic arterial pressure was above } 1.25 \\
\text { times the baseline the infusion was stopped } \\
\text { and restarted at half the rate when the systolic } \\
\text { arterial pressure was below } 1.25 \text { times the } \\
\text { baseline again. The max nausea and vomiting } \\
\text { score was recorded between spinal and } \\
\text { delivery. At delivery one of the investigators } \\
\text { obtained umbilical artery and vein blood } \\
\text { samples from a segment of the umbilical cord } \\
\text { double clamped before the baby's first } \\
\text { breath. No supplemental O2 was given to the } \\
\text { mother prior to delivery. APGAR scores } \\
\text { recorded at } 1 \text { and } 5 \text { minutes by a midwife and } \\
\text { the need for tracheal intubation, ventilation or } \\
\text { admission to the special care baby unit were } \\
\text { recorded. }\end{array}$ & $\begin{array}{l}\text { Blood gas values were similar for the } \mathrm{P} \text { and } \\
\mathrm{C} \text { groups. The } \mathrm{E} \text { group had a lower } \\
\text { umbilical artery pH than the } \mathrm{P} \text { group } \\
(\mathrm{P}=0.002) \text { or the } \mathrm{C} \text { group }(\mathrm{P}=0.009) \text {, and a } \\
\text { lower umbilical vein } \mathrm{pH} \text { than the } \mathrm{P} \text { group } \\
(\mathrm{P}=0.04 \text { ) or the } \mathrm{C} \text { group }(\mathrm{P}=0.003) \text {. There } \\
\text { was no difference in the umbilical vein } \\
\mathrm{PCO} 2 \text { between the groups but the } \mathrm{E} \text { group } \\
\text { had a higher umbilical artery } \mathrm{PCO} 2 \text { than the } \\
\mathrm{P} \text { group }(\mathrm{P}=0.002) \text {. Baseline } \mathrm{N} / \mathrm{V} \\
\text { (nausea/vomiting) scores were similar for } \\
\text { all } 3 \text { groups. There was no change in the } \mathrm{P} \\
\text { group from baseline } \mathrm{N} / \mathrm{V} \text { scores }(\mathrm{P}=0.30) \\
\text { but in the } \mathrm{E} \text { and } \mathrm{C} \text { group the } \mathrm{N} / \mathrm{V} \text { scores } \\
\text { increased from baseline }(\mathrm{E}=\mathrm{P}<0.0001)(\mathrm{C}= \\
\mathrm{P}=0.007) \text {. The } \mathrm{N} / \mathrm{V} \text { scores were lower in the } \\
\mathrm{P} \text { group than in the } \mathrm{E} \text { group }(\mathrm{P}<0.0001) \text { or } \\
\mathrm{C} \text { group }(\mathrm{P}<0.0001) \text { but there was no } \\
\text { significant different between the } \mathrm{E} \text { and } \mathrm{C} \\
\text { groups }(\mathrm{P}=0.09) \text {. In the } \mathrm{E} \text { group vomiting } \\
\text { (n=18) was associated with decreased } \mathrm{HR} \\
\text { and } \mathrm{SABP} \text { and increased ephedrine doses. } \\
\text { There was no difference in the block height } \\
\text { at } 10 \text { min or at skin incision for the } \mathrm{E} \text { group } \\
\text { participants who vomited, compared with } \\
\text { the } \mathrm{E} \text { group participants without } \mathrm{N} / \mathrm{V} \\
(\mathrm{P}=0.57 \text { and } \mathrm{P}=0.36) \text {. } \\
\text { The incidence of fetal acidosis and vomiting } \\
\text { at cesarean delivery under spinal anesthesia } \\
\text { was reduced by giving phenylephrine alone } \\
\text { or in combo with ephedrine compared with } \\
\text { giving ephedrine alone. }\end{array}$ \\
\hline
\end{tabular}




\section{Appendix A-3}

Ngan Kee, W. D., Khaw, K. S., Lau, T. K., Ng, F. F., Chui, K., \& Ng, K. L. (2008). Randomized double-blinded comparison of phenylephrine vs. ephedrine for maintaining blood pressure during spinal anesthesia for the non-elective Caesarean section.

\begin{tabular}{|c|c|c|c|c|c|}
\hline $\begin{array}{c}\text { Method/level } \\
\text { of evidence \& } \\
\text { Major } \\
\text { variables } \\
\text { studied }\end{array}$ & $\begin{array}{c}\text { Sample/ } \\
\text { Setting }\end{array}$ & Intervention & Data Analysis & Results & Limitations \\
\hline $\begin{array}{l}\text { Randomized/D } \\
\text { ouble blind } \\
\text { study using } \\
\text { computer- } \\
\text { generated } \\
\text { codes } \\
\text { contained in } \\
\text { opaque seal } \\
\text { and } \\
\text { sequentially } \\
\text { numbered } \\
\text { envelopes. } \\
\text { Level II } \\
\text { evidence } \\
\text { Maternal: } \\
\text { blood pressure } \\
\text { and heart rate } \\
\text { and Nausea } \\
\text { and vomiting } \\
\text { Fetal: Apgar } \\
\text { score and } \\
\text { umbilical } \\
\text { artery blood }\end{array}$ & $\begin{array}{l}204 \text { (n=204) } \\
\text { Inclusion: } \\
\text { ASA I and II } \\
\text { women with } \\
\text { singleton } \\
\text { pregnancies } \\
\text { scheduled for } \\
\text { non-elective } \\
\text { C-section for } \\
\text { which spinal } \\
\text { anesthesia } \\
\text { was decided } \\
\text { upon for } \\
\text { clinical } \\
\text { reasons at any } \\
\text { point in time. } \\
\text { Exclusion: } \\
\text { participants } \\
\text { with pre- } \\
\text { existing or } \\
\text { pregnancy } \\
\text { induced } \\
\text { hypertension, } \\
\text { cardiovascula }\end{array}$ & $\begin{array}{l}\text { participants were premedicated with } \\
0.3 \mathrm{M} \text { Na citrate } 30 \mathrm{ml} \text { on arrival to the } \\
\text { OR. Standard monitoring included } \\
\text { noninvasive BP measurement, ECG and } \\
\text { pulse Oximetry. Fetal HR (heart rate) } \\
\text { was monitored by external } \\
\text { cardiotocography until surgical prep. No } \\
\text { IV prehydration was given. Spinal } \\
\text { anesthesia was induced with the patient } \\
\text { in the right lateral position. After skin } \\
\text { infiltration with lidocaine, a } 25 \text {-gauge } \\
\text { pencil point needle was inserted at what } \\
\text { was estimated to be L3-4 or L4-5 } \\
\text { vertebral interspace and } 2.0-2.2 \text { ml of } \\
\text { hyperbaric } 0.5 \% \text { bupivacaine (10-20 } \\
\text { mg) and fentanyl } 15 \text { mcg was injected } \\
\text { intrathecally. The patient was then } \\
\text { immediately turned to supine with a left } \\
\text { lateral tilt and a rapid IV co-hydration } \\
\text { with up to } 2 \text { liters of lactated ringer's } \\
\text { solution, oxygen of } 6-8 \text { L/min was } \\
\text { administered by clear facemask until } \\
\text { delivery. BP (blood pressure) was } \\
\text { measured at } 1 \text { min intervals beginning at } \\
1 \text { minute after spinal injection. }\end{array}$ & $\begin{array}{l}85 \text { participants } \\
\text { ( } \mathrm{n}=85 \text { ) per group } \\
\text { would be required } \\
\text { to have a } 90 \% \\
\text { power at the } 0.05 \\
\text { significance level } \\
\text { to detect a } \\
\text { difference } \\
\text { between groups. } \\
\text { Primary analysis } \\
\text { was performed on } \\
\text { an intention to } \\
\text { treat basis and a } \\
\text { secondary } \\
\text { analysis was } \\
\text { performed on a } \\
\text { per protocol basis } \\
\text { to compare only } \\
\text { protocol- } \\
\text { compliant } \\
\text { participants who } \\
\text { actually required } \\
\text { treatment for } \\
\text { hypotension with } \\
\text { a vasopressor. }\end{array}$ & 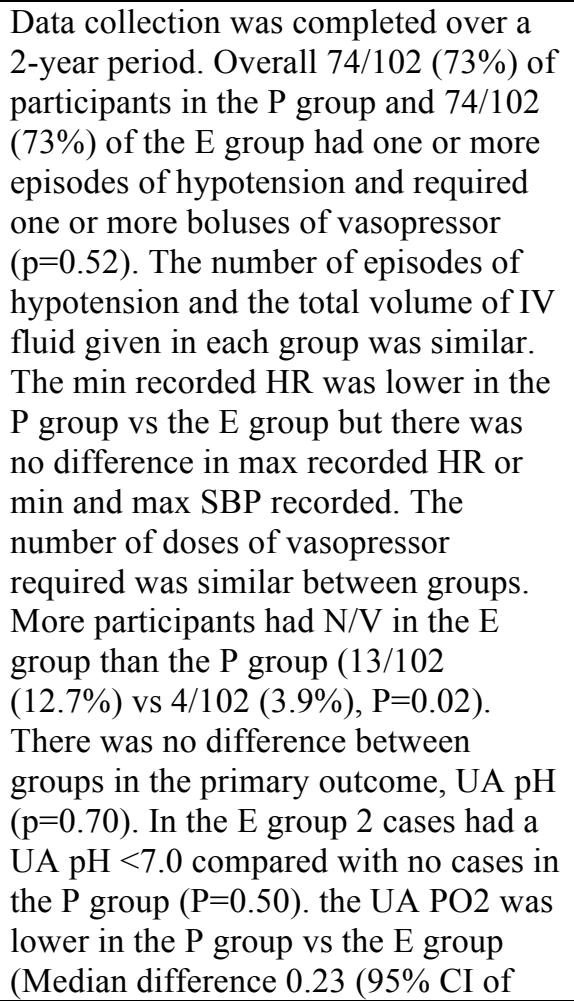 & $\begin{array}{l}\text { Insufficient } \\
\text { amount of UA } \\
\text { blood was } \\
\text { obtained in } 1 \\
\text { patient in the P } \\
\text { group and } 2 \\
\text { participants in } \\
\text { the E group. } \\
\text { Insufficient UV } \\
\text { blood was } \\
\text { obtained for } \\
\text { analysis in } 2 \\
\text { participants in } \\
\text { the E group. } 8 \\
\text { UA sample and } \\
1 \text { UV sample } \\
\text { was below the } \\
\text { min reportable } \\
\text { limit range. } \\
\text { After the study } \\
\text { commenced a } \\
\text { study was } \\
\text { published by } \\
\text { Saravanan et al. } \\
\text { reporting that }\end{array}$ \\
\hline
\end{tabular}




\begin{tabular}{|c|c|c|c|c|c|}
\hline $\begin{array}{l}\text { gases and } \\
\text { venous blood } \\
\text { gases }\end{array}$ & $\begin{array}{l}\mathrm{r} \text { or } \\
\text { cerebrovascul } \\
\text { ar disease, } \\
\text { multiple } \\
\text { gestation, } \\
\text { known fetal } \\
\text { abnormality } \\
\text { or any } \\
\text { medical } \\
\text { contraindicati } \\
\text { ons to spinal } \\
\text { anesthesia } \\
\text { such as } \\
\text { thrombocytop } \\
\text { enia or } \\
\text { coagulopathy }\end{array}$ & $\begin{array}{l}\text { Hypotension as defined as SBP (systolic } \\
\text { blood pressure) }<100 \text { mmHg. } \\
\text { participants were randomized to receive } \\
\text { an IV bolus of either phenylephrine } 100 \\
\text { mcg (group P) or ephedrine } 10 \mathrm{mg} \\
\text { (group E) immediately after each } \\
\text { episode of hypotension. The doses of the } \\
\text { drugs were chosen based on clinical } \\
\text { experience. The upper sensory level of } \\
\text { the spinal anesthesia was tested at } 5 \text { min } \\
\text { after the spinal injection. Skin incision, } \\
\text { uterine incision and delivery were all } \\
\text { recorded. Vasopressor protocol was } \\
\text { continued until the time of uterine } \\
\text { incision. The total dose of vasopressor } \\
\text { given up to time of uterine decision, the } \\
\text { total volume of IV fluid given and any } \\
\text { incidence of nausea or vomiting and the } \\
\text { number of episodes of hypotension was } \\
\text { recorded. Bradycardia was defined as } \\
\text { HR <50 bpm. The attending pediatrician } \\
\text { assessed APGAR scores at } 1 \text { and } 5 \text { min } \\
\text { after delivery. We recorded the number } \\
\text { of neonates admitted to the special care } \\
\text { baby unit and neonatal intensive care } \\
\text { unit and the duration of stays. Umbilical } \\
\text { arterial (UA) and umbilical venous (UV) } \\
\text { blood samples from double-clamped } \\
\text { segments of umbilical cord were } \\
\text { obtained. }\end{array}$ & $\begin{array}{l}\text { Univariate } \\
\text { intergroup } \\
\text { comparisons were } \\
\text { made using the } \\
\text { unpaired student's } \\
\text { t-test or the } \\
\text { Mann-Whitney U- } \\
\text { test as } \\
\text { appropriate. } \\
\text { Nominal data } \\
\text { were compared } \\
\text { using the Chi- } \\
\text { Square test or } \\
\text { Fisher's exact } \\
\text { test. Analyses } \\
\text { were made using } \\
\text { SPSS version } \\
10.1 .4 \text { and } \\
\text { confidence } \\
\text { interval Analysis } \\
2.0 .0 \text {. Values of } \\
\text { p }<0.05 \text { were } \\
\text { considered } \\
\text { statistically } \\
\text { significant. }\end{array}$ & $\begin{array}{l}\text { difference } 0.20-0.45) \mathrm{p}=0.032) \text { and UV } \\
\text { PO2 was lower in the P group vs the E } \\
\text { group (Median difference } 0.39(95 \% \mathrm{CI} \\
\text { of difference } 0.08-0.70) \mathrm{P}=0.012) \text {. } \\
\text { However, there was no difference } \\
\text { between groups in UA or UV oxygen } \\
\text { content. There was no difference } \\
\text { between groups in the clinical outcome } \\
\text { of the neonates. One neonate in the E } \\
\text { group had an APGAR score }<7 \text { at } 1 \\
\text { min and } 5 \text { min and one neonate in the P } \\
\text { group had an APGAR score }<7 \text { at } 1 \\
\text { min; all other APGAR score were }>7 . \\
17 \text { neonates ( } 17 \% \text { ) in the P group and } \\
21(21 \%) \text { neonates in the E group were } \\
\text { admitted to the special care baby unit } \\
\text { (P=0.045). There was no difference in } \\
\text { the duration of stay between groups. In } \\
\text { the ephedrine group UA lactate was } \\
\text { higher and UV lactate was higher, UA } \\
\text { pO2 and UV PO2 were lower in the P } \\
\text { group although O2 content was similar. } \\
\text { More participants had nausea or } \\
\text { vomiting in the E group but there was } \\
\text { no other difference in clinical outcome. } \\
\text { Both Phenylephrine and Ephedrine are } \\
\text { suitable vasopressors for use in non- } \\
\text { elective C-sections. }\end{array}$ & $\begin{array}{l}\text { the potency } \\
\text { ratio of } \\
\text { phenylephrine: } \\
\text { ephedrine was } \\
\text { approximately } \\
80: 1 \\
\text { (Phenylephrine } \\
100 \text { mcg = } \\
\text { ephedrine } 8 \mathrm{mg} \text { ) } \\
\text { when the drugs } \\
\text { were given by } \\
\text { infusion } \\
\text { therefore the } \\
\text { doses used in } \\
\text { this study were } \\
\text { not equipotent. } \\
\text { There was a } \\
\text { relatively small } \\
\text { amount of } \\
\text { vasopressors } \\
\text { used in this } \\
\text { study and that } \\
\text { may explain the } \\
\text { findings to be } \\
\text { not lower in the } \\
\text { E group as } \\
\text { predicted in } \\
\text { multiple } \\
\text { previous } \\
\text { studies. }\end{array}$ \\
\hline
\end{tabular}




\section{Appendix A-4}

Prakash, S., Pramanik, V., Chellani, H., Salhan, S., \& Gogia, A. R. (2010). Maternal and neonatal effects of bolus administration of ephedrine and phenylephrine during spinal anesthesia for caesarean delivery: a randomized study. International Journal of Obstetric Anesthesia, 19(1), 24-30.

\begin{tabular}{|c|c|c|c|c|c|}
\hline $\begin{array}{c}\text { Method/level } \\
\text { of evidence } \\
\& \\
\text { Major } \\
\text { variables } \\
\text { studied }\end{array}$ & $\begin{array}{c}\text { Sample/ } \\
\text { Setting }\end{array}$ & Intervention & Data Analysis & Results & Limitations \\
\hline $\begin{array}{l}\text { Randomized/ } \\
\text { Double blind } \\
\text { study with } \\
\text { computer } \\
\text { generated } \\
\text { number } \\
\text { allocation } \\
\text { Level II } \\
\text { evidence } \\
\text { Maternal: } \\
\text { blood } \\
\text { pressure and } \\
\text { heart rate } \\
\text { Fetal: Apgar } \\
\text { score and } \\
\text { umbilical } \\
\text { artery pH and } \\
\text { venous pH }\end{array}$ & $\begin{array}{l}\text { A total of } 60 \\
\text { women who } \\
\text { developed } \\
\text { hypotension } \\
\text { participated. } \\
\mathrm{n}=30 \text { in the } \\
\text { ephedrine } \\
\text { group, } \mathrm{n}=30 \text { in } \\
\text { the } \\
\text { Phenylephrine } \\
\text { group } \\
\text { Inclusion: } \\
\text { ASA } 1 \text { women } \\
\text { with singleton } \\
\text { pregnancies } \\
\text { scheduled for } \\
\text { elective } \\
\text { caesarean } \\
\text { delivery under } \\
\text { spinal } \\
\text { anesthesia } \\
\text { were recruited. }\end{array}$ & $\begin{array}{l}\text { All women received ranitidine and metoclopramide } \\
\text { for antacid prophylaxis. Standard monitoring with } \\
\text { on-invasive arterial pressure, electrocardiography } \\
\text { and pulse oximetry was established. } \\
\text { Women rested undisturbed in the supine position } \\
\text { with left uterine displacement for } 5 \text { min following } \\
\text { which baseline blood pressure and heart rate were } \\
\text { calculated as the mean of three successive readings } \\
\text { measured } 1 \text { min apart. Each patient also received a } \\
10 \mathrm{ml} / \mathrm{kg} \text { IV infusion of Lactated Ringers solution } \\
\text { over } 15-20 \text { min before spinal anesthesia. } \\
\text { With participants in the left lateral position, } 2 \mathrm{ml} \\
0.5 \% \text { Hyperbaric Bupivacaine was injected } \\
\text { intrathecally at L3-4 via a } 25 \text { gauge Quincke needle. } \\
\text { participants were then immediately turned supine } \\
\text { and positioned with left uterine displacement. Heart } \\
\text { rate and blood pressure were recorded at } 1 \text { min } \\
\text { intervals from the time of induction of spinal } \\
\text { anesthesia until delivery. Oxygen } 6 \mathrm{~L} / \text { min via face } \\
\text { mask was delivered until delivery. Sensory block to } \\
\text { the T5 dermatome was considered adequate for } \\
\text { surgery. }\end{array}$ & $\begin{array}{l}\text { A total of } 23 \\
\text { women per } \\
\text { group would } \\
\text { have a } 90 \% \\
\text { power at the } 5 \% \\
\text { significance } \\
\text { level to detect a } \\
\text { difference in } \\
\text { umbilical } \\
\text { arterial pH of } \\
0.03 \text { between } \\
\text { groups. To } \\
\text { allow for } \\
\text { potential drop- } \\
\text { outs a total of } \\
30 \text { participants } \\
\text { per group with a } \\
\text { SBP < } 80 \% \text { of } \\
\text { baseline were } \\
\text { recruited } \\
\text { Descripting } \\
\text { statistics were } \\
\text { calculated for }\end{array}$ & $\begin{array}{l}\text { The two groups were } \\
\text { comparable in age, weight, } \\
\text { height, baseline hemodynamic } \\
\text { data and dermatomal sensory } \\
\text { levels. There were no } \\
\text { significant differences in the } \\
\text { mean induction to delivery or } \\
\text { uterine to delivery intervals } \\
\text { between the two groups. } \\
\text { Although not significant, } \\
\text { induction to delivery times } \\
\text { varied, hemodynamic changes } \\
\text { were compared up to } 20 \text { min } \\
\text { after induction of spinal } \\
\text { anesthesia, by which time } 59 \\
\text { out of } 60 \text { women had } \\
\text { delivered. The mean change } \\
\text { in systolic pressure was } \\
\text { comparable in the two groups } \\
\text { with the minimum being } 100 \\
\text { in the } \mathrm{E} \text { group and } 93 \text { in the } \mathrm{P} \\
\text { group (P=0.114) except at } 8 \\
\text { minutes where E group was } \\
\text { lower ( } \mathrm{P}=0.004) \text {. The fall in }\end{array}$ & $\begin{array}{l}\text { Sample size } \\
\text { was small. All } \\
\text { participants } \\
\text { were healthy } \\
\text { women } \\
\text { undergoing } \\
\text { elective C- } \\
\text { section } \\
\text { delivery so } \\
\text { extrapolation } \\
\text { to situations } \\
\text { where fetal } \\
\text { compromise is } \\
\text { present or to } \\
\text { emergency C- } \\
\text { section } \\
\text { delivery may } \\
\text { not be valid. } \\
\text { There was a } \\
\text { high baseline } \\
\text { blood pressure } \\
\text { than could of } \\
\text { been due to the } \\
\text { setting where }\end{array}$ \\
\hline
\end{tabular}




\begin{tabular}{|c|c|c|c|c|}
\hline $\begin{array}{l}\text { Exclusion: } \\
\text { Women with } \\
\text { pre-existing or } \\
\text { pregnancy } \\
\text { induced } \\
\text { hypertension, } \\
\text { diabetes } \\
\text { mellitus, } \\
\text { known } \\
\text { cardiovascular } \\
\text { or } \\
\text { cerebrovascula } \\
\text { r disease, fetal } \\
\text { abnormality, } \\
\text { or } \\
\text { contraindicatio } \\
\mathrm{n} \text { to spinal } \\
\text { anesthesia. }\end{array}$ & $\begin{array}{l}\text { Women were randomly assigned to received one of } \\
\text { two vasopressor solutions whenever systolic pressure } \\
\text { decreased to } 80 \% \text { of baseline or less. } \\
\text { participants were divided into } 2 \text { groups: P group } \\
\text { (phenylephrine) and E group (ephedrine). Group E } \\
\text { received } 1 \mathrm{ml} \text { bolus of ephedrine } 6 \mathrm{mg} / \mathrm{ml} \text {, group P } \\
\text { received a } 1 \mathrm{ml} \text { bolus of phenylephrine } 100 \mathrm{mcg} / \mathrm{ml} \text {. } \\
\text { Additional boluses were administered if the systolic } \\
\text { pressure remained at or below } 80 \% \text { of baseline. } \\
\text { Atropine was administered in } 0.3 \mathrm{mg} \text { increments } \\
\text { whenever bradycardia was associated with systolic } \\
\text { pressure less than baseline or if the heart rate was } \\
<45 \text { bpm The incidence of maternal tachycardia } \\
\text { (>100 bpm) and reactive hypertension ( }>20 \% \text { of } \\
\text { baseline) were recorded after the administration of } \\
\text { either ephedrine in group E or phenylephrine in } \\
\text { group P. The number of vasopressor doses required, } \\
\text { total doses of vasopressor administered, time of first } \\
\text { administration of vasopressor, requirement for } \\
\text { atropine and its relation to vasopressor } \\
\text { administration were noted. The time of induction of } \\
\text { spinal anesthesia, uterine incision and delivery were } \\
\text { recorded. After delivery oxytocin } 5 \text { units was given } \\
\text { by slow IV injection followed by a } 10 \text {-unit infusion. } \\
\text { The incidence of nausea and vomiting was recorded. } \\
\text { Arterial and venous blood samples were obtained } \\
\text { from a double clamped segment of the umbilical } \\
\text { cord and analyzed within } 10 \text { minutes. Apgar scores } \\
\text { at } 1,5 \text { and } 10 \text { minutes were determined by the } \\
\text { attending pediatrician who was unaware of group } \\
\text { assignment. Time and onset of sustained rhythmic } \\
\text { respiration was noted. }\end{array}$ & $\begin{array}{l}\text { continuous } \\
\text { variables as } \\
\text { mean and } \\
\text { standard } \\
\text { deviation and } \\
\text { for categorical } \\
\text { variables as } \\
\text { frequency of } \\
\text { distribution and } \\
\text { percentage. To } \\
\text { assess trend } \\
\text { within } \\
\text { variables, two- } \\
\text { way analysis of } \\
\text { variance was } \\
\text { used. P }<0.05 \\
\text { was regarded as } \\
\text { statistically } \\
\text { significant. } \\
\text { SPSS } 14.0 \text { for } \\
\text { Windows } \\
\text { statistical } \\
\text { software was } \\
\text { used for } \\
\text { analysis. }\end{array}$ & $\begin{array}{l}\text { heart rate below mean baseline } \\
\text { in group P was significantly } \\
\text { greater than in group E ( } 20 \pm \\
10 \text { vs } 6 \pm 0.6, \mathrm{P}<0.001) \text {. In all } \\
\text { cases, bradycardia developed } \\
\text { following phenylephrine } \\
\text { administration. Birth weight } \\
\text { and Apgar scores at } 1 \\
(\mathrm{p}=0.739), 5 \text { ( } \mathrm{p}=0.128) \text { and } 10 \\
\text { min }(\mathrm{p}=0.611) \text { were } \\
\text { comparable in the two groups. } \\
\text { No neonate had an Apgar } \\
\text { score }<7 \text { at any time. Time to } \\
\text { onset of rhythmic respiration } \\
\text { was }<90 \text { s in all cases. No } \\
\text { neonate required tracheal } \\
\text { intubation or admission to the } \\
\text { neonatal intensive care unit. } \\
\text { No umbilical artery pH was } \\
\text { less than } 7.20 . \text { Umbilical } \\
\text { artery and venous } p H \text { were } \\
\text { significantly lower in group E } \\
\text { than in group P ( } p=0.01 \text { and } \\
\mathrm{P}=0.002) \\
\text { Results showed the } 100 \text { mcg } \\
\text { bolus doses of phenylephrine } \\
\text { are as effective as } 6 \text { mg bolus } \\
\text { doses of ephedrine in the } \\
\text { treatment of hypotension } \\
\text { following spinal anesthesia in } \\
\text { term parturients undergoing c- } \\
\text { section delivery. Neonates of } \\
\text { women treated with } \\
\text { phenylephrine had higher } \\
\text { umbilical cord } p H \text { though true } \\
\text { fetal acidosis was not seen in } \\
\text { any neonate. }\end{array}$ & $\begin{array}{l}\text { the baseline } \\
\text { was taken that } \\
\text { being the OR } \\
\text { which is a high } \\
\text { stress } \\
\text { environment. } \\
\text { All } \\
\text { participants } \\
\text { were fluid } \\
\text { preloaded } \\
\text { which could } \\
\text { also add to the } \\
\text { high baseline } \\
\text { blood } \\
\text { pressures. The } \\
\text { doses of } \\
\text { ephedrine and } \\
\text { phenylephrine } \\
\text { used were } \\
\text { based on } \\
\text { clinical } \\
\text { experience of } \\
\text { the authors }\end{array}$ \\
\hline
\end{tabular}


Data Collection Tool

\section{Appendix A-5}

Mercier, F. J., Augè, M., Hoffmann, C., Fischer, C., \& Le Gouez, A. (2013). Maternal hypotension during spinal anesthesia for caesarean delivery. Minerva Anestesiol, 79(1), 62-73.

\begin{tabular}{|c|c|c|c|c|c|}
\hline $\begin{array}{c}\text { Method/ } \\
\text { level of } \\
\text { evidence } \\
\& \\
\text { Major } \\
\text { variable } \\
\text { s studied }\end{array}$ & $\begin{array}{l}\text { Sample/ } \\
\text { Setting }\end{array}$ & Intervention & Data Analysis & Results & Limitations \\
\hline $\begin{array}{l}\text { Randomi } \\
\text { zed } \\
\text { double- } \\
\text { blind } \\
\text { study } \\
\text { using a } \\
\text { random } \\
\text { table } \\
\text { with } \\
\text { stratificat } \\
\text { ion to } \\
\text { allocate } \\
\text { participa } \\
\text { nts to } \\
\text { each } \\
\text { group } \\
\text { Level II } \\
\text { evidence } \\
\text { Maternal } \\
\text { : blood } \\
\text { pressure }\end{array}$ & $\begin{array}{l}42 \text { parturients } \\
\text { (n=42) } \\
\text { scheduled for } \\
\text { Caesarean } \\
\text { section (C- } \\
\text { section) } \\
\text { delivery } \\
\text { using spinal } \\
\text { anesthesia. } \\
\text { Inclusion: age } \\
\text { 18-years or } \\
\text { older, weight } \\
\text { 90Kg or less, } \\
\text { height } 152 \mathrm{~cm} \\
\text { or greater, } \\
\text { ASA I or II, } \\
\text { and term } \\
\text { singleton } \\
\text { pregnancy. } \\
\text { Exclusion: } \\
\text { parturients } \\
\text { with }\end{array}$ & $\begin{array}{l}\text { Participants were fasted overnight and were given } \\
30 \mathrm{ml} \text { of sodium citrate. Oxygen was administered } \\
\text { to all participants via nasal cannula. Standard } \\
\text { monitors included electrocardiogram, noninvasive } \\
\text { BP device and pulse oximetry. After an } \\
\text { intravenous (IV) preload of } 15 \mathrm{ml} / \mathrm{kg} \text { of Lactated } \\
\text { Ringer's Solution (LR) was given, spinal } \\
\text { anesthesia was performed at the L2-L3 or L3-L4 } \\
\text { interspace with the patient sitting, using a } 9 \mathrm{~cm} 25 \\
\text { gauge whitacre spinal needle. } 11 \mathrm{mg} \text { of hyperbaric } \\
0.5 \% \text { Bupivacaine, } 2.5 \text { mcg Sufentanil and } 0.1 \mathrm{mg} \\
\text { morphine was injected through the spinal needle. } \\
\text { Participants were then immediately placed in the } \\
\text { recumbent position with left uterine displacement. } \\
\text { A prophylactic vasopressor IV infusion was started } \\
\text { at the end of spinal injection. participants received } \\
\text { either } 2 \mathrm{mg} / \text { min ephedrine plus } 10 \text { mcg/min } \\
\text { phenylephrine (E+P group) or } 2 \mathrm{mg} / \text { min ephedrine } \\
\text { alone (E group). Study solutions were prepared by } \\
\text { an anesthesiologist or a nurse anesthetist not } \\
\text { involved in the participant's care and according to } \\
\text { the group indicated in a numbered sealed } \\
\text { envelope. One of the investigators was present }\end{array}$ & $\begin{array}{l}\text { Data was expressed } \\
\text { as mean } \pm \text { SD } \\
\text { unless stated } \\
\text { otherwise. Groups } \\
\text { were compared for } \\
\text { single parametric, } \\
\text { ordinal and } \\
\text { nominal variables } \\
\text { suing unpaired } \\
\text { student } t \text { test, the } \\
\text { Mann-Whitney U } \\
\text { test, and Fisher } \\
\text { exact test, } \\
\text { respectively. } \\
\text { Hemodynamic } \\
\text { values over time } \\
\text { were compared } \\
\text { using analysis of } \\
\text { variance for } \\
\text { repeated measures, } \\
\text { followed by } \\
\text { Dunnett tests. A } \\
\text { forward stepwise }\end{array}$ & $\begin{array}{l}\text { Participants characteristics, } \\
\text { gestational age, neonatal weight, } \\
\text { upper sensory level of anesthesia at } \\
20 \text { min and time intervals from } \\
\text { spinal anesthesia to incision, from } \\
\text { spinal anesthesia to delivery and } \\
\text { from uterine incision to delivery } \\
\text { were comparable between the two } \\
\text { groups. Baseline SBP and maternal } \\
\text { HR were also comparable between } \\
\text { the groups. } \\
\text { The incidence of hypotension was } \\
\text { halved in the E+P ( } 37 \% \text { group } \\
\text { when compared with the E ( } 75 \% \text { ) } \\
\text { group (P=0.02). SBP values after } \\
\text { onset of spinal anesthesia were not } \\
\text { significantly different between the } \\
\text { two groups. Minimal SBP values } \\
\text { before delivery were lower in the E } \\
\text { group but the difference was no } \\
\text { statistically significant (P=0.08). } \\
\text { Hypotensive episodes were brief } \\
\text { and of similar cumulative duration }\end{array}$ & $\begin{array}{l}\text { Phenylephrine } \\
\text { alone group } \\
\text { studied would } \\
\text { have allowed } \\
\text { for a broader } \\
\text { knowledge } \\
\text { base. } \\
\text { Hypotension } \\
\text { was found to } \\
\text { be very } \\
\text { frequent in } \\
\text { this study and } \\
\text { more } \\
\text { prophylaxis } \\
\text { should be } \\
\text { used. }\end{array}$ \\
\hline
\end{tabular}




\begin{tabular}{|c|c|c|c|c|}
\hline $\begin{array}{l}\text { Fetal: } \\
\text { Umbilica } \\
1 \text { cord } \\
\text { blood pH } \\
\text { and } \\
\text { Apgar } \\
\text { scores }\end{array}$ & $\begin{array}{l}\text { pregnancy- } \\
\text { induced } \\
\text { hypertension, } \\
\text { cardiac } \\
\text { disease, } \\
\text { diabetes, or } \\
\text { fetal } \\
\text { complications } \\
\text {, and those in } \\
\text { labor }\end{array}$ & $\begin{array}{l}\text { during the study period to confirm comparability } \\
\text { of routine procedures. The primary outcome } \\
\text { variable was the incidence of hypotension, defined } \\
\text { as a systolic blood pressure (SBP) }<100 \mathrm{mmHg} \\
\text { and less than } 80 \% \text { of baseline before delivery. } \\
\text { Baseline SBP and maternal heart rate (HR) were } \\
\text { determined by the average of } 3 \text { measurements } \\
\text { obtained before preloading with LR. After spinal } \\
\text { injection SBP and maternal HR were measured } \\
\text { every minute for } 10 \text { min and every } 2 \text { min there } \\
\text { after until delivery. A predefined algorithm was } \\
\text { used to adjust the syringe rate according to SBP as } \\
\text { follows: } \\
\text {-maintain rate if SBP within } 90-105 \% \text { of baseline } \\
\text {-Rate halved if SBP } 105-120 \% \text { of baseline } \\
\text {-Stop if SBP }>120 \% \text { of baseline } \\
\text {-Rate doubled if SBP } 80-90 \% \text { of baseline } \\
\text {-SBP }<100 \text { mmHg and }<80 \% \text { of baseline treated } \\
\text { with } 6 \mathrm{mg} \text { ephedrine bolus doses repeated as } \\
\text { needed. } \\
\text { For each subject, a min and max SBP and HR } \\
\text { were recorded before delivery. A back up plan } \\
\text { designed to treat several critical situations allowed } \\
\text { anesthesiologist to administer epinephrine, } \\
\text { addition phenylephrine or atropine as needed. The } \\
\text { upper level of sensory changes was determined } \\
\text { using an alcohol swab } 20 \text { min after spinal } \\
\text { injection. Additional data collection included time } \\
\text { intervals from spinal anesthesia to incision, from } \\
\text { spinal anesthesia to delivery, and from uterine } \\
\text { incision to delivery, the dose of vasopressor } \\
\text { infused until delivery, venous and arterial } \\
\text { umbilical cord pH values, neonatal Apgar scores } \\
\text { and neonatal weight. }\end{array}$ & $\begin{array}{l}\text { regression analysis } \\
\text { was performed to } \\
\text { determine the } \\
\text { association } \\
\text { between venous or } \\
\text { arterial umbilical } \\
\text { blood pH with the } \\
\text { following five } \\
\text { variables: duration } \\
\text { of hypotension, } \\
\text { total ephedrine } \\
\text { dose, time interval } \\
\text { from spinal } \\
\text { anesthesia to skin } \\
\text { incision, time from } \\
\text { spinal anesthesia to } \\
\text { delivery, and time } \\
\text { from uterine } \\
\text { incision to } \\
\text { delivery. }<0.05 \\
\text { was considered } \\
\text { significant. Sample } \\
\text { size calculations } \\
\text { indicated that } \\
\text { including } 37 \\
\text { participants in the } \\
\text { study would result } \\
\text { in an } 80 \% \text { power to } \\
\text { detect a decrease } \\
\text { from } 75 \text { to } 37.5 \% \\
\text { in the incidence of } \\
\text { hypotension at a } \\
\text { significance level } \\
\text { of } 0.05\end{array}$ & $\begin{array}{l}\text { in both groups. Max SBP and Min } \\
\text { heart rate were also comparable. } \\
\text { Max heart rate before delivery was } \\
15 \text { bpm higher in the E group than } \\
\text { in the } \mathrm{E}+\mathrm{P} \text { group ( } \mathrm{P}=0.02) \text {. } \\
\text { Maternal heart rate after onset of } \\
\text { spinal anesthesia was significantly } \\
\text { increased in the } \mathrm{E} \text { group from } 3 \text { to } 6 \\
\text { min after spinal anesthesia }(\mathrm{P}<0.05 \text { ) } \\
\text { and remained unchanged in the } \mathrm{E}+\mathrm{P} \\
\text { group. Significantly more ephedrine } \\
\text { was infused and supplementation } \\
\text { given in the E group. Umbilical } \\
\text { venous and arterial pH values were } \\
\text { significantly higher in the } \mathrm{E}+\mathrm{P} \\
\text { group }(7.24) \text { than in the } \mathrm{E} \text { group } \\
\text { (7.19) (P=0.05). } \\
\text { The incidence of arterial } \mathrm{pH}<7.20 \\
\text { was } 31 \% \text { higher in the } \mathrm{E}+\mathrm{P} \text { group } \\
\text { and } 63 \% \text { in the } \mathrm{E} \text { group }(\mathrm{P}=0.09 \text { ). } \\
\text { However, Apgar scores at } 1 \text { and } 5 \\
\text { min were similar in both groups } \\
\text { (p=0.7) and were never less than } 7 . \\
\text { Low venous and arterial } \mathrm{pH} \text { values } \\
\text { were associated only with the } \mathrm{E} \\
\text { group assignment and spinal } \\
\text { anesthesia to delivery times longer } \\
\text { than } 33 \text { min. } \\
\text { Compared with ephedrine alone } \\
\text { ephedrine plus phenylephrine } \\
\text { infusions decreased the incidence of } \\
\text { hypotension by approx. } 50 \% \text {, } \\
\text { abolished maternal tachycardia, and } \\
\text { improved venous and arterial pH. }\end{array}$ \\
\hline
\end{tabular}




\section{Appendix A-6}

Moslemi, F., \& Rasooli, S. (2015). Comparison of prophylactic infusion of phenylephrine with ephedrine for prevention of hypotension in elective cesarean section under spinal anesthesia: a randomized clinical trial. Iranian Journal of Medical Sciences, $40(1), 19$.

\begin{tabular}{|c|c|c|c|c|c|}
\hline $\begin{array}{l}\text { Method/level of } \\
\text { evidence \& } \\
\text { Major variables } \\
\text { studied }\end{array}$ & $\begin{array}{c}\text { Sample/ } \\
\text { Setting }\end{array}$ & Intervention & $\begin{array}{c}\text { Data } \\
\text { Analysis }\end{array}$ & Results & Limitations \\
\hline $\begin{array}{l}\text { Randomized/Double } \\
\text { blind study using a } \\
\text { table of random } \\
\text { numbers and a } \\
\text { computer generated } \\
\text { randomization list. } \\
\text { Level II evidence } \\
\text { Maternal: blood } \\
\text { pressure and heart } \\
\text { rate } \\
\text { Fetal: Apgar score } \\
\text { and umbilical artery } \\
\text { blood gases }\end{array}$ & $\begin{array}{l}90 \text { women } \\
(\mathrm{n}=90) \text { for } \\
\text { elective c- } \\
\text { section under } \\
\text { spinal } \\
\text { anesthesia were } \\
\text { recruited. } \\
\text { Inclusion: } \\
\text { healthy } \\
\text { pregnant } \\
\text { women with } \\
\text { gestational age } \\
\text { of } 36 \text { weeks or } \\
\text { higher and non- } \\
\text { emergency c- } \\
\text { section } \\
\text { Exclusion: }<36 \\
\text { weeks of } \\
\text { gestation, } \\
\text { emergency c- } \\
\text { section, high } \\
\text { risk } \\
\text { pregnancies } \\
\text { (multiple }\end{array}$ & $\begin{array}{l}\text { participants were assigned to } 3 \text { different } \\
\text { groups: phenylephrine (group Ph), } \\
\text { ephedrine (group E) and placebo (group P). } \\
\text { Upon arrival to the OR all participants were } \\
\text { monitored for basal vital signs (HR, SBP, } \\
\text { DBP, and SaO2). Prior to spinal anesthesia } \\
\text { all participants received a } 500 \mathrm{ml} \\
\text { crystalloid bolus. Infusion of study drugs } \\
\text { were: group Ph received } 450 \mathrm{mcg} \text { of } \\
\text { phenylephrine in } 250 \mathrm{ml} \text {, group E received } \\
45 \text { mg of ephedrine in } 250 \text { ml and group P } \\
\text { received an infusion of only } 250 \text { ml normal } \\
\text { saline. All solutions were label with } \\
\text { numerical codes. The nurses that infused } \\
\text { the solutions and monitored the vital signs } \\
\text { were blinded to the solutions. The } \\
\text { participants then received spinal anesthesia } \\
\text { by an anesthesiologist in the sitting position } \\
\text { from L4/5 or L3/4 inter-vertebral spaces } \\
\text { with } 2.5 \text { ml of Bupivacaine } 0.5 \% \text { ( } 12.5 \mathrm{mg} \text { ) } \\
\text { and } 2.5 \text { mcg of Sufentanil. Immediately } \\
\text { after spinal placement all participants were } \\
\text { positioned in the supine position with left } \\
\text { uterine displacement. BP (blood pressure) } \\
\text { was controlled every } 2 \text { minutes until }\end{array}$ & $\begin{array}{l}\text { Data was } \\
\text { analyzed } \\
\text { using a one- } \\
\text { way } \\
\text { ANOVA for } \\
\text { quantitative } \\
\text { variables and } \\
\text { Fishers exact } \\
\text { probability } \\
\text { tests and chi- } \\
\text { square for } \\
\text { qualitative } \\
\text { variables and } \\
\text { associations. } \\
\text { Multiple } \\
\text { comparisons } \\
\text { were tested } \\
\text { by post-hoc } \\
\text { with Turkey } \\
\text { technique. } \\
\text { Normal } \\
\text { distributions } \\
\text { of data were } \\
\text { evaluated by } \\
\text { Kolmogorov- }\end{array}$ & $\begin{array}{l}\text { In total } 83 \text { participants }(\mathrm{n}=83) \text { were } \\
\text { studied: } 30 \text { women in group } \mathrm{Ph} \\
(\mathrm{n}=30), 27 \text { in group } \mathrm{E}(\mathrm{n}=27) \text { and } 26 \\
\text { in group } \mathrm{P}(\mathrm{n}-26) \text {. There was no } \\
\text { significant difference in } \\
\text { demographic data. Indications for c- } \\
\text { section were: repeated c-section } \\
(\mathrm{n}=53) \text {, other indications ( } \mathrm{n}=25) \text { and } \\
\text { patient preference ( } \mathrm{n}=4) \text {. } \\
\text { There was no significant difference } \\
\text { between the } 3 \text { groups in basal SBP } \\
\text { (systolic blood pressure), how ever } \\
\text { SBP after anesthesia every } 2 \text { and } \\
\text { every } 5 \text { minutes were different } \\
\text { (P>0.050) in the } \mathrm{Ph} \text { and } \mathrm{P} \text { groups. } \\
\text { There was no significant difference } \\
\text { between groups for HR (heart rate) } \\
\text { except for the } 1 \text { st } 3 \text { measurements of } \\
\text { every } 5 \text { minutes ( } \mathrm{P}=0.006) .38 \\
\text { participants in all groups had severe } \\
\text { hypotension and needed additional } \\
\text { vasopressor therapy: group Ph=10, } \\
\text { group E-15, group } \mathrm{P}=20 \text {. There was } \\
\text { a significant difference between } \\
\text { group } \mathrm{Ph} \text { and groups } \mathrm{E} \text { and } \mathrm{P} \text {. }\end{array}$ & $\begin{array}{l}\text { Sample size } \\
\text { was small. } \\
\text { All } \\
\text { participants } \\
\text { were healthy } \\
\text { women } \\
\text { undergoing } \\
\text { elective C- } \\
\text { section } \\
\text { delivery so } \\
\text { extrapolation } \\
\text { to situations } \\
\text { where fetal } \\
\text { compromise } \\
\text { is present or } \\
\text { to emergency } \\
\text { C-section } \\
\text { delivery may } \\
\text { not be valid. } \\
\text { All } \\
\text { participants } \\
\text { were fluid } \\
\text { preloaded } \\
\text { which could } \\
\text { also add to }\end{array}$ \\
\hline
\end{tabular}




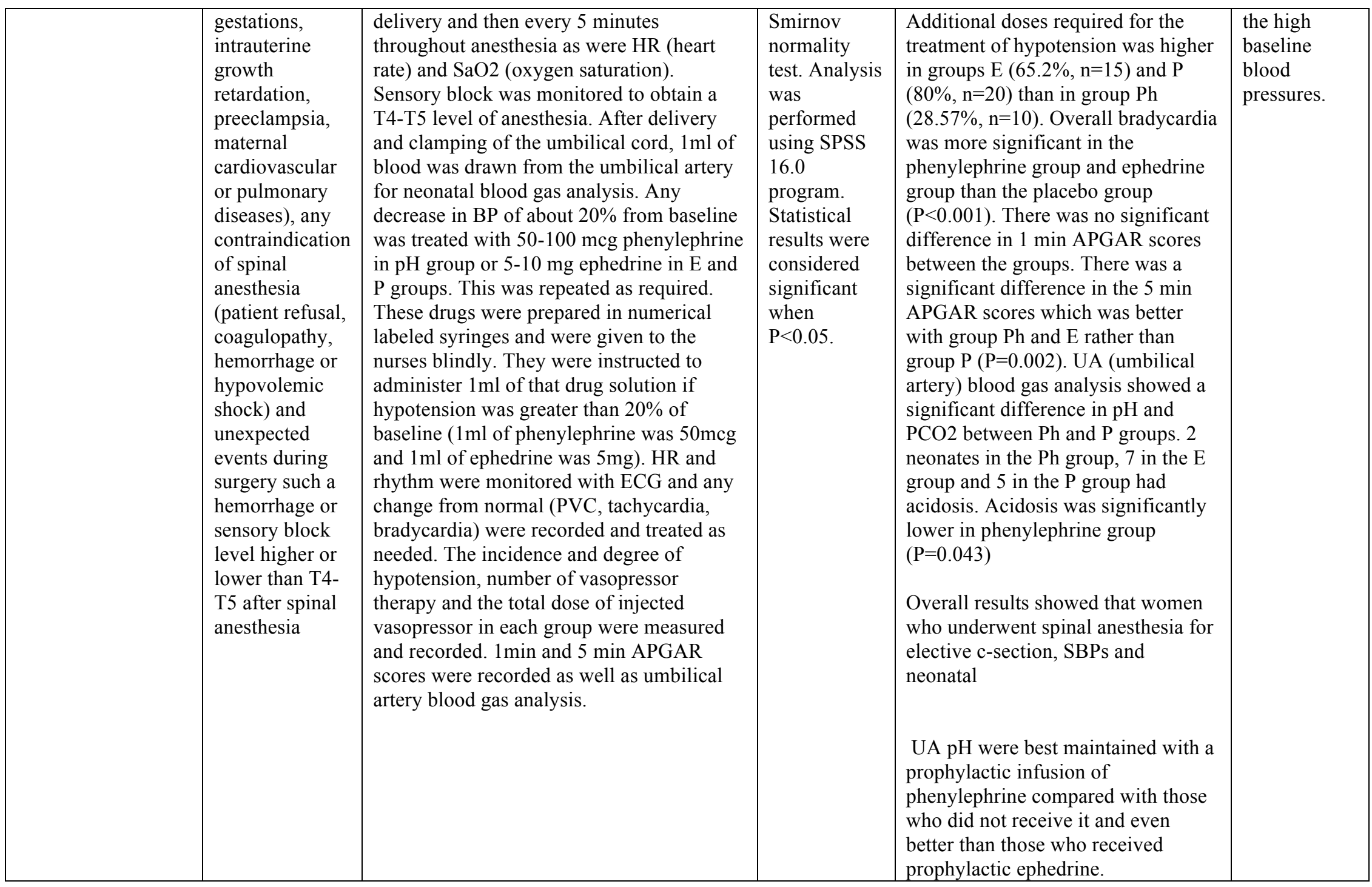




\section{CASE worksheet}

\section{Appendix B-1}

Cooper, D. W., Sharma, S., Orakkan, P., \& Gurung, S. (2010). Retrospective study of association between choice of vasopressor given during spinal anesthesia for high-risk caesarean delivery and fetal pH. International Journal of Obstetric Anesthesia, 19(1), 4449.

\begin{tabular}{|c|c|}
\hline \multicolumn{2}{|c|}{$\begin{array}{l}\text { Critical Appraisal for Summaries of Evidence (CASE) Worksheet } \\
\text { *Numbers in evaluation correspond with those assigned to articles in data extrapolation chart* }\end{array}$} \\
\hline Questions & Evaluation \\
\hline \multicolumn{2}{|c|}{ Summary Topic } \\
\hline $\begin{array}{l}\text { 1. Is the summary specific in scope and } \\
\text { application? }\end{array}$ & $\begin{array}{l}\text { Yes- The aim of the study is clearly stated as well } \\
\text { as the patients that the summary applies to are } \\
\text { well described }\end{array}$ \\
\hline \multicolumn{2}{|c|}{ Summary Methods } \\
\hline $\begin{array}{l}\text { 2. Is the authorship of the summary } \\
\text { transparent? }\end{array}$ & $\begin{array}{l}\text { No - The individual authors are listed but their } \\
\text { credentialing is not listed. Affiliation is listed. }\end{array}$ \\
\hline $\begin{array}{l}\text { 3. Are the reviewer(s)/editor(s) of the } \\
\text { summary transparent? }\end{array}$ & $\begin{array}{l}\text { No- It is not clearly stated that the summary has } \\
\text { been edited and reviewed }\end{array}$ \\
\hline $\begin{array}{l}\text { 4. Are the research methods transparent } \\
\text { and comprehensive? }\end{array}$ & $\begin{array}{l}\text { Yes- The inclusion and exclusion criteria is clearly } \\
\text { stated. A protocol for the study was Cleary stated } \\
\text { and followed. }\end{array}$ \\
\hline $\begin{array}{l}\text { 5. Is the evidence grading system } \\
\text { transparent and translatable? }\end{array}$ & $\begin{array}{l}\text { Yes- Retrospective observational/chart review } \\
\text { study was performed. Protocol used in reviewing } \\
\text { charts was clearly stated. }\end{array}$ \\
\hline \multicolumn{2}{|c|}{ Summary Content } \\
\hline 6. Are the recommendations clear? & $\begin{array}{l}\text { Yes- recommendations are clearly stated and } \\
\text { multiple options for treatment are provided }\end{array}$ \\
\hline $\begin{array}{l}\text { 7. Are the recommendations appropriately } \\
\text { cited? }\end{array}$ & Yes- recommendations are appropriately cited \\
\hline 8. Are the recommendations current? & $\begin{array}{l}\text { No- The recommendations are from } 2010 \text { so not } \\
\text { within } 2 \text { years therefore not updated or current }\end{array}$ \\
\hline 9. Is the summary unbiased? & $\begin{array}{l}\text { Unable to appropriately assess if there is a } \\
\text { conflict of interest between the } \\
\text { recommendations of the summary and the } \\
\text { sponsor for any author }\end{array}$ \\
\hline \multicolumn{2}{|c|}{ Summary Application } \\
\hline $\begin{array}{l}\text { 10. Can this summary be applied to your } \\
\text { patient(s)? }\end{array}$ & $\begin{array}{l}\text { Yes- This evidence and setting applies to my } \\
\text { population and can be translated to any patient } \\
\text { within the same population and setting. }\end{array}$ \\
\hline
\end{tabular}


CASE worksheet

\title{
Appendix B-2
}

\author{
Cooper, D. W., Carpenter, M., Mowbray, P., Desira, W. R., Ryall, D. M., \& Kokri, M. S. \\ (2002). Fetal and maternal effects of phenylephrine and ephedrine during spinal \\ anesthesia for cesarean delivery. The Journal of the American Society of \\ Anesthesiologists, 97(6), 1582-1590.
}

\begin{tabular}{|l|l|}
\hline \multicolumn{2}{|c|}{ Critical Appraisal for Summaries of Evidence (CASE) Worksheet } \\
\hline \multicolumn{2}{|c|}{ Questions } \\
*Numbers in evaluation correspond with those assigned to articles in data extrapolation chart*
\end{tabular}


CASE worksheet

Appendix B-3

Ngan Kee, W. D., Khaw, K. S., Lau, T. K., Ng, F. F., Chui, K., \& Ng, K. L. (2008). Randomized double-blinded comparison of phenylephrine vs. ephedrine for maintaining blood pressure during spinal anesthesia for the non-elective Caesarean section. Anesthesia, 63(12), 1319-1326.

\begin{tabular}{|c|c|}
\hline $\begin{array}{l}\text { Critical Appraisal for Summar } \\
\text { *Numbers in evaluation correspond with thos }\end{array}$ & $\begin{array}{l}\text { of Evidence (CASE) Worksheet } \\
\text { ssigned to articles in data extrapolation chart* }\end{array}$ \\
\hline Questions & Evaluation \\
\hline \multicolumn{2}{|c|}{ Summary Topic } \\
\hline $\begin{array}{l}\text { 1. Is the summary specific in scope and } \\
\text { application? }\end{array}$ & $\begin{array}{l}\text { Yes- The aim of the study is clearly stated as well } \\
\text { as the patients that the summary applies to are } \\
\text { well described }\end{array}$ \\
\hline \multicolumn{2}{|c|}{ Summary Methods } \\
\hline $\begin{array}{l}\text { 2. Is the authorship of the summary } \\
\text { transparent? }\end{array}$ & $\begin{array}{l}\text { Not completely- Although the individual authors } \\
\text { are listed their credentialing is not listed but their } \\
\text { affiliations are. The process to become in author } \\
\text { is also not described. }\end{array}$ \\
\hline $\begin{array}{l}\text { 3. Are the reviewer(s)/editor(s) of the } \\
\text { summary transparent? }\end{array}$ & $\begin{array}{l}\text { No- It is not clearly stated that the summary has } \\
\text { been edited and reviewed }\end{array}$ \\
\hline $\begin{array}{l}\text { 4. Are the research methods transparent } \\
\text { and comprehensive? }\end{array}$ & $\begin{array}{l}\text { Yes- The inclusion and exclusion criteria is clearly } \\
\text { stated. A protocol for the study was Cleary stated } \\
\text { and followed. }\end{array}$ \\
\hline $\begin{array}{l}\text { 5. Is the evidence grading system } \\
\text { transparent and translatable? }\end{array}$ & $\begin{array}{l}\text { Yes- Randomized double-blinded study - stated } \\
\text { that randomization was performed using } \\
\text { computer generated codes contained in opaque, } \\
\text { sealed and sequentially numbered envelops as } \\
\text { well as medications prepared in identical syringes } \\
\text { but someone not involved in the study }\end{array}$ \\
\hline \multicolumn{2}{|c|}{ Summary Content } \\
\hline 6. Are the recommendations clear? & $\begin{array}{l}\text { Yes- recommendations are clearly stated and } \\
\text { multiple options for treatment are provided }\end{array}$ \\
\hline $\begin{array}{l}\text { 7. Are the recommendations appropriately } \\
\text { cited? }\end{array}$ & Yes- recommendations are appropriately cited \\
\hline 8. Are the recommendations current? & $\begin{array}{l}\text { No- The recommendations are from } 2008 \text { so not } \\
\text { within } 2 \text { years therefore not updated or current }\end{array}$ \\
\hline 9. Is the summary unbiased? & $\begin{array}{l}\text { Unable to appropriately assess if there is a } \\
\text { conflict of interest between the } \\
\text { recommendations of the summary and the } \\
\text { sponsor for any author }\end{array}$ \\
\hline \multicolumn{2}{|c|}{ Summary Application } \\
\hline $\begin{array}{l}\text { 10. Can this summary be applied to your } \\
\text { patient(s)? }\end{array}$ & $\begin{array}{l}\text { Yes- This evidence and setting applies to my } \\
\text { population and can be translated to any patient } \\
\text { within the same population and setting. }\end{array}$ \\
\hline
\end{tabular}




\section{CASE worksheet}

\section{Appendix B-4}

Prakash, S., Pramanik, V., Chellani, H., Salhan, S., \& Gogia, A. R. (2010). Maternal and neonatal effects of bolus administration of ephedrine and phenylephrine during spinal anesthesia for caesarean delivery: a randomized study. International Journal of Obstetric Anesthesia, 19(1), 24-30.

\begin{tabular}{|c|c|}
\hline $\begin{array}{r}\text { Critical Appraisal for Summar } \\
{ }^{*} \text { Numbers in evaluation correspond with thos }\end{array}$ & $\begin{array}{l}\text { of Evidence (CASE) Worksheet } \\
\text { assigned to articles in data extrapolation chart* }\end{array}$ \\
\hline Questions & Evaluation \\
\hline \multicolumn{2}{|c|}{ Summary Topic } \\
\hline $\begin{array}{l}\text { 1. Is the summary specific in scope and } \\
\text { application? }\end{array}$ & $\begin{array}{l}\text { Yes- The aim of the study is clearly stated as well } \\
\text { as the patients that the summary applies to are } \\
\text { well described }\end{array}$ \\
\hline \multicolumn{2}{|c|}{ Summary Methods } \\
\hline $\begin{array}{l}\text { 2. Is the authorship of the summary } \\
\text { transparent? }\end{array}$ & $\begin{array}{l}\text { Not completely - The individual authors are listed } \\
\text { but their credentialing is not listed. Affiliation is } \\
\text { listed. }\end{array}$ \\
\hline $\begin{array}{l}\text { 3. Are the reviewer(s)/editor(s) of the } \\
\text { summary transparent? }\end{array}$ & $\begin{array}{l}\text { No- It is not clearly stated that the summary has } \\
\text { been edited and reviewed }\end{array}$ \\
\hline $\begin{array}{l}\text { 4. Are the research methods transparent } \\
\text { and comprehensive? }\end{array}$ & $\begin{array}{l}\text { Yes- The inclusion and exclusion criteria is clearly } \\
\text { stated. A protocol for the study was Cleary stated } \\
\text { and followed. }\end{array}$ \\
\hline $\begin{array}{l}\text { 5. Is the evidence grading system } \\
\text { transparent and translatable? }\end{array}$ & $\begin{array}{l}\text { Yes- Randomized double-blinded study - stated } \\
\text { that randomization was performed by computer } \\
\text { generated number allocation, identical syringes } \\
\text { prepared by someone not involved with data } \\
\text { collection. }\end{array}$ \\
\hline \multicolumn{2}{|c|}{ Summary Content } \\
\hline 6. Are the recommendations clear? & $\begin{array}{l}\text { Yes- recommendations are clearly stated and } \\
\text { multiple options for treatment are provided }\end{array}$ \\
\hline $\begin{array}{l}\text { 7. Are the recommendations appropriately } \\
\text { cited? }\end{array}$ & 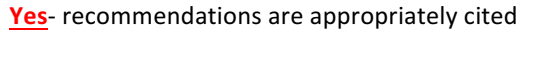 \\
\hline 8. Are the recommendations current? & $\begin{array}{l}\text { No- The recommendations are from } 2009 \text { so not } \\
\text { within } 2 \text { years therefore not updated or current }\end{array}$ \\
\hline 9. Is the summary unbiased? & $\begin{array}{l}\text { Unable to appropriately assess if there is a } \\
\text { conflict of interest between the } \\
\text { recommendations of the summary and the } \\
\text { sponsor for any author }\end{array}$ \\
\hline \multicolumn{2}{|c|}{ Summary Application } \\
\hline $\begin{array}{l}\text { 10. Can this summary be applied to your } \\
\text { patient(s)? }\end{array}$ & $\begin{array}{l}\text { Yes- This evidence and setting applies to my } \\
\text { population and can be translated to any patient } \\
\text { within the same population and setting. }\end{array}$ \\
\hline
\end{tabular}




\title{
CASE worksheet
}

\section{Appendix B-5}

\author{
Mercier, F. J., Augè, M., Hoffmann, C., Fischer, C., \& Le Gouez, A. (2013). Maternal \\ hypotension during spinal anesthesia for caesarean delivery. Minerva Anestesiol, 79(1), \\ $62-73$.
}

\begin{tabular}{|c|c|}
\hline \multicolumn{2}{|c|}{$\begin{array}{c}\text { Critical Appraisal for Summaries of Evidence (CASE) Worksheet } \\
{ }^{*} \text { Numbers in evaluation correspond with those assigned to articles in data extrapolation chart* }\end{array}$} \\
\hline Questions & Evaluation \\
\hline \multicolumn{2}{|c|}{ Summary Topic } \\
\hline $\begin{array}{l}\text { 1. Is the summary specific in scope and } \\
\text { application? }\end{array}$ & $\begin{array}{l}\text { Yes- The aim of the study is clearly stated as well } \\
\text { as the patients that the summary applies to are } \\
\text { well described }\end{array}$ \\
\hline \multicolumn{2}{|c|}{ Summary Methods } \\
\hline $\begin{array}{l}\text { 2. Is the authorship of the summary } \\
\text { transparent? }\end{array}$ & $\begin{array}{l}\text { Yes - The individual authors are listed with their } \\
\text { credentialing and affiliations. }\end{array}$ \\
\hline $\begin{array}{l}\text { 3. Are the reviewer(s)/editor(s) of the } \\
\text { summary transparent? }\end{array}$ & $\begin{array}{l}\text { No- It is not clearly stated that the summary has } \\
\text { been edited and reviewed }\end{array}$ \\
\hline $\begin{array}{l}\text { 4. Are the research methods transparent } \\
\text { and comprehensive? }\end{array}$ & $\begin{array}{l}\text { Yes- The inclusion and exclusion criteria is clearly } \\
\text { stated. A protocol for the study was Cleary stated } \\
\text { and followed. }\end{array}$ \\
\hline $\begin{array}{l}\text { 5. Is the evidence grading system } \\
\text { transparent and translatable? }\end{array}$ & $\begin{array}{l}\text { Yes- Randomized double-blinded study - stated } \\
\text { that randomization was performed by using } \\
\text { numbered, sealed, opaque envelopes ensuring } \\
\text { both the patient and investigators were blinded } \\
\text { to group assignment and study solutions were } \\
\text { prepared by those not involved in the patients } \\
\text { care and according to the group indicated by the } \\
\text { envelope. There was an investigator present } \\
\text { during the study period to confirm comparability } \\
\text { and routine procedures. }\end{array}$ \\
\hline \multicolumn{2}{|c|}{ Summary Content } \\
\hline 6. Are the recommendations clear? & $\begin{array}{l}\text { Yes- recommendations are clearly stated and } \\
\text { multiple options for treatment are provided }\end{array}$ \\
\hline $\begin{array}{l}\text { 7. Are the recommendations appropriately } \\
\text { cited? }\end{array}$ & Yes- recommendations are appropriately cited \\
\hline 8. Are the recommendations current? & $\begin{array}{l}\text { No- The recommendations are from } 2001 \text { so not } \\
\text { within } 2 \text { years therefore not updated or current }\end{array}$ \\
\hline 9. Is the summary unbiased? & $\begin{array}{l}\text { Unable to appropriately assess if there is a } \\
\text { conflict of interest between the } \\
\text { recommendations of the summary and the } \\
\text { sponsor for any author }\end{array}$ \\
\hline \multicolumn{2}{|c|}{ Summary Application } \\
\hline $\begin{array}{l}\text { 10. Can this summary be applied to your } \\
\text { patient(s)? }\end{array}$ & $\begin{array}{l}\text { Yes- This evidence and setting applies to my } \\
\text { population and can be translated to any patient } \\
\text { within the same population and setting. }\end{array}$ \\
\hline
\end{tabular}




\section{CASE worksheet}

\section{Appendix B-6}

Moslemi, F., \& Rasooli, S. (2015). Comparison of prophylactic infusion of phenylephrine with ephedrine for prevention of hypotension in elective cesarean section under spinal anesthesia: a randomized clinical trial. Iranian Journal of Medical Sciences, 40(1), 19.

\begin{tabular}{|c|c|}
\hline $\begin{array}{l}\text { Critical Appraisal for Summar } \\
\text { *Numbers in evaluation correspond with thos }\end{array}$ & $\begin{array}{l}\text { of Evidence (CASE) Worksheet } \\
\text { Issigned to articles in data extrapolation chart* }\end{array}$ \\
\hline Questions & Evaluation \\
\hline \multicolumn{2}{|c|}{ Summary Topic } \\
\hline $\begin{array}{l}\text { 1. Is the summary specific in scope and } \\
\text { application? }\end{array}$ & $\begin{array}{l}\text { Yes- The aim of the study is clearly stated as well } \\
\text { as the patients that the summary applies to are } \\
\text { well described }\end{array}$ \\
\hline \multicolumn{2}{|c|}{ Summary Methods } \\
\hline $\begin{array}{l}\text { 2. Is the authorship of the summary } \\
\text { transparent? }\end{array}$ & $\begin{array}{l}\text { Yes - The individual authors are listed with their } \\
\text { credentialing as well as affiliations. }\end{array}$ \\
\hline $\begin{array}{l}\text { 3. Are the reviewer(s)/editor(s) of the } \\
\text { summary transparent? }\end{array}$ & $\begin{array}{l}\text { No- It is not clearly stated that the summary has } \\
\text { been edited and reviewed }\end{array}$ \\
\hline $\begin{array}{l}\text { 4. Are the research methods transparent } \\
\text { and comprehensive? }\end{array}$ & $\begin{array}{l}\text { Yes- The inclusion and exclusion criteria is clearly } \\
\text { stated. A protocol for the study was Cleary stated } \\
\text { and followed. }\end{array}$ \\
\hline $\begin{array}{l}\text { 5. Is the evidence grading system } \\
\text { transparent and translatable? }\end{array}$ & $\begin{array}{l}\text { Yes- Randomized clinical trial - stated that } \\
\text { randomization was performed using a table of } \\
\text { random numbers and computer generated } \\
\text { randomization list }\end{array}$ \\
\hline \multicolumn{2}{|c|}{ Summary Content } \\
\hline 6. Are the recommendations clear? & $\begin{array}{l}\text { Yes- recommendations are clearly stated and } \\
\text { multiple options for treatment are provided }\end{array}$ \\
\hline $\begin{array}{l}\text { 7. Are the recommendations appropriately } \\
\text { cited? }\end{array}$ & Yes- recommendations are appropriately cited \\
\hline 8. Are the recommendations current? & $\begin{array}{l}\text { Yes- The recommendations are from 2015, they } \\
\text { are current. }\end{array}$ \\
\hline 9. Is the summary unbiased? & $\begin{array}{l}\text { Unable to appropriately assess if there is a } \\
\text { conflict of interest between the } \\
\text { recommendations of the summary and the } \\
\text { sponsor for any author }\end{array}$ \\
\hline \multicolumn{2}{|c|}{ Summary Application } \\
\hline $\begin{array}{l}\text { 10. Can this summary be applied to your } \\
\text { patient(s)? }\end{array}$ & $\begin{array}{l}\text { Yes- This evidence and setting applies to my } \\
\text { population and can be translated to any patient } \\
\text { within the same population and setting. }\end{array}$ \\
\hline
\end{tabular}




\section{Appendix C}

Descriptive Data Synthesis

\begin{tabular}{|c|c|c|c|c|c|c|c|c|c|}
\hline Study & $\begin{array}{c}\text { Oxygen } \\
\text { supplementation } \\
\text { Used }\end{array}$ & $\begin{array}{c}\text { Intravenous } \\
\text { Fluid } \\
\text { Prehydration }\end{array}$ & $\begin{array}{c}\text { ASA } \\
\text { Classification/ } \\
\text { patient } \\
\text { characteristics }\end{array}$ & $\begin{array}{l}\text { Hypotension } \\
\text { incidence } \\
\text { after spinal } \\
\text { Anesthesia }\end{array}$ & $\begin{array}{c}\text { Spinal } \\
\text { Solution } \\
\text { and } \\
\text { Technique }\end{array}$ & $\begin{array}{l}\text { Umbilical } \\
\text { Artery pH }\end{array}$ & $\begin{array}{l}\text { Apgar } \\
\text { scores }\end{array}$ & $\begin{array}{l}\text { N/V during } \\
\text { case }\end{array}$ & $\begin{array}{c}\text { Other } \\
\text { important } \\
\text { findings }\end{array}$ \\
\hline $\begin{array}{l}\text { Cooper } \\
\text { et al., } \\
2010\end{array}$ & Not reported & Not reported & $\begin{array}{l}\text { High risk } \\
\text { singleton } \\
\text { pregnant } \\
\text { patients }\end{array}$ & $\begin{array}{l}\text { SBP }<90 \\
\text { mmHg: No } \\
\text { vasopressor } \\
\text { group } 6.1 \% \text {, } \\
\text { group E } 17 \% \\
\text { and group } \mathrm{P} \\
20 \% \\
(\mathrm{P}=0.005)\end{array}$ & $\begin{array}{l}\text { No detail but } \\
\text { reported to } \\
\text { be non } \\
\text { consistent }\end{array}$ & $\begin{array}{l}\text { On direct } \\
\text { comparison } \\
\text { there was } \\
\text { no } \\
\text { difference } \\
\text { in the } \\
\text { incidence of } \\
\text { umbilical } \\
\text { artery pH } \\
<7.20 \\
(\mathrm{P}=0.21),\end{array}$ & $\begin{array}{l}\text { On direct } \\
\text { comparis } \\
\text { on there } \\
\text { was no } \\
\text { difference } \\
\text { in } 5 \text { min } \\
\text { Apgar } \\
\text { score }<7 \\
(0.089) \text {, }\end{array}$ & & $\begin{array}{l}\text { Following } \\
\text { forward } \\
\text { stepwise } \\
\text { multiple } \\
\text { regression } \\
\text { analysis, } \\
\text { the only } \\
\text { variable } \\
\text { that was } \\
\text { associated } \\
\text { with } \\
\text { altered pH } \\
\text { was non- } \\
\text { reassuring } \\
\text { fetal heart } \\
\text { rate trace } \\
(\mathrm{P}=0.71) \text {. }\end{array}$ \\
\hline $\begin{array}{l}\text { Cooper } \\
\text { et al., } \\
2002\end{array}$ & $\begin{array}{l}\text { No supplemental } \\
\text { O2 was given to } \\
\text { the mother prior } \\
\text { to delivery. }\end{array}$ & $\begin{array}{l}\text { Immediately } \\
\text { before spinal } \\
\text { anesthesia a } \\
\text { preload of } \\
10 \mathrm{ml} / \mathrm{kg} \text { of } \\
\text { Hartmann } \\
\text { solution as } \\
\text { rapidly } \\
\text { infused. }\end{array}$ & $\begin{array}{l}\text { ASA I and II } \\
\text { participants } \\
\text { scheduled for } \\
\text { elective C- } \\
\text { section under } \\
\text { spinal } \\
\text { anesthesia. } \\
\text { Singleton } \\
\text { pregnancies, } \\
\text { with no fetal } \\
\text { abnormalities }\end{array}$ & $\begin{array}{l}\text { The lowest } \\
\text { SABP } \\
\text { recorded was } \\
\text { higher in the } \\
\text { P group ( } 80 \% \\
\text { [73-88] of } \\
\text { baseline) than } \\
\text { in the E } \\
\text { group ( } 73 \% \\
\text { [61-87] of } \\
\text { baseline) }\end{array}$ & $\begin{array}{l}4 \text { different } \\
\text { spinal } \\
\text { anesthetic } \\
\text { solutions/tec } \\
\text { hniques } \\
\text { were used } \\
\text { based on } \\
\text { provider } \\
\text { presence } \\
\text { To avoid } \\
\text { bias, }\end{array}$ & $\begin{array}{l}\text { Fetal } \\
\text { acidosis } \\
\text { was less } \\
\text { frequent in } \\
\text { the P group } \\
\text { (1 of } 48) \\
\text { and less } \\
\text { frequent in } \\
\text { the } C \text { group } \\
\text { (1 of } 47) \\
\text { than in the }\end{array}$ & $\begin{array}{l}1 \text { and } 5 \\
\text { min } \\
\text { APGAR } \\
\text { scores } \\
\text { were } \\
\text { good in } \\
\text { all } 3 \\
\text { groups }\end{array}$ & $\begin{array}{l}\text { Baseline N/V } \\
\text { (nausea/vomi } \\
\text { ting) scores } \\
\text { were similar } \\
\text { for all } 3 \\
\text { groups. There } \\
\text { was no } \\
\text { change in the } \\
\text { P group from } \\
\text { baseline N/V } \\
\text { scores }\end{array}$ & \\
\hline
\end{tabular}




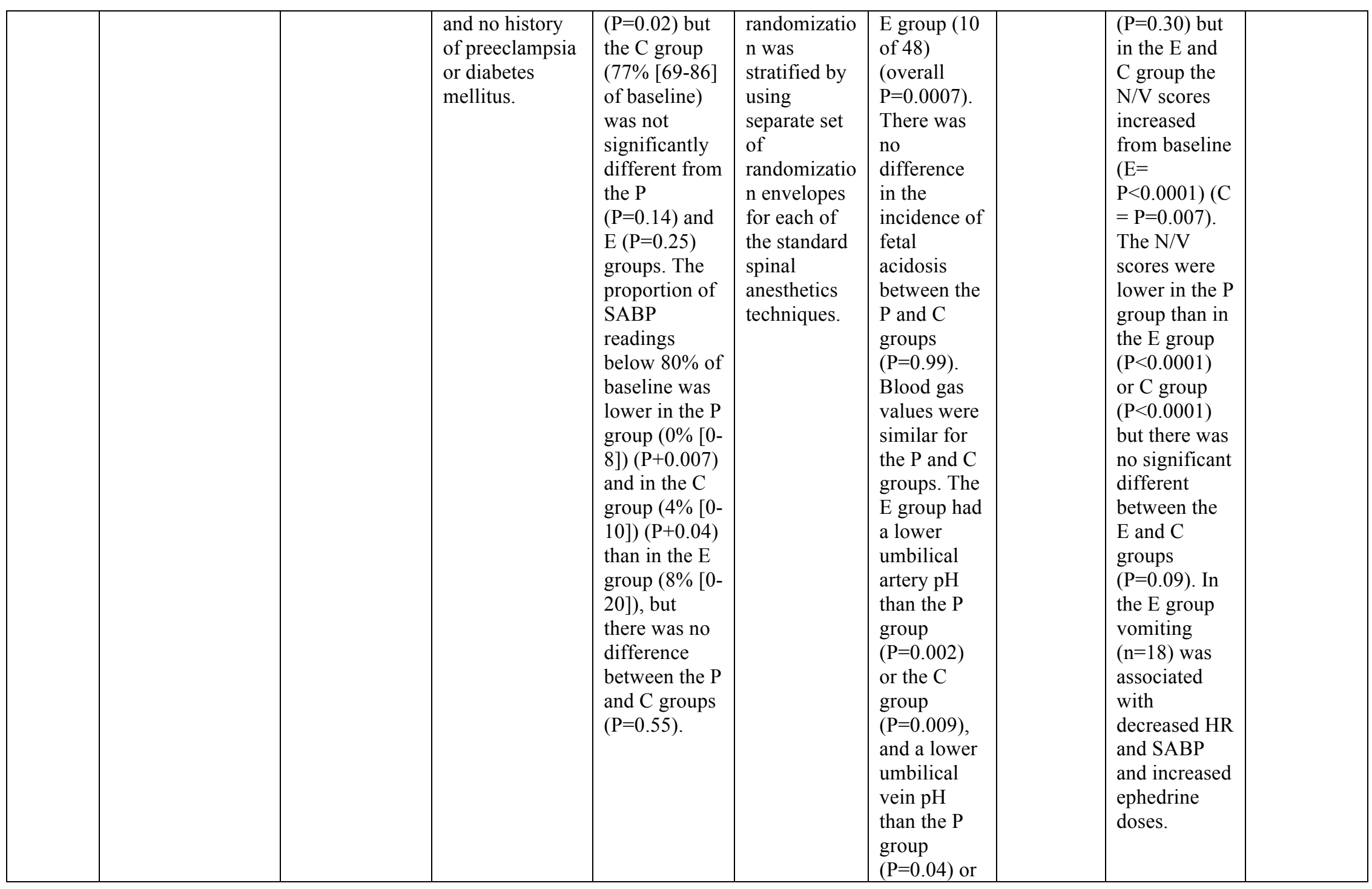




\begin{tabular}{|c|c|c|c|c|c|c|c|c|c|}
\hline & & & & & & $\begin{array}{l}\text { the } \mathrm{C} \text { group } \\
(\mathrm{P}=0.003) .\end{array}$ & & & \\
\hline $\begin{array}{l}\text { Ngan } \\
\text { Kee, et } \\
\text { al., } \\
2008\end{array}$ & $\begin{array}{l}\text { After spinal } \\
\text { administration and } \\
\text { patient positioned } \\
\text { supine oxygen of } \\
6-8 \mathrm{~L} / \text { min was } \\
\text { administered by } \\
\text { clear facemask } \\
\text { until delivery }\end{array}$ & $\begin{array}{l}\text { No IV } \\
\text { prehydration } \\
\text { was given } \\
\text { After spinal } \\
\text { administration } \\
\text { and patient } \\
\text { positioned } \\
\text { supine a rapid } \\
\text { IV co- } \\
\text { hydration with } \\
\text { up to } 2 \text { liters of } \\
\text { lactated } \\
\text { ringer's } \\
\text { solution was } \\
\text { given. }\end{array}$ & $\begin{array}{l}\text { ASA I and II } \\
\text { women with } \\
\text { singleton } \\
\text { pregnancies } \\
\text { scheduled for } \\
\text { non-elective C- } \\
\text { section for } \\
\text { which spinal } \\
\text { anesthesia was } \\
\text { decided upon } \\
\text { for clinical } \\
\text { reasons at any } \\
\text { point in time. }\end{array}$ & $\begin{array}{l}\text { Overall } \\
74 / 102(73 \%) \\
\text { of } \\
\text { participants } \\
\text { in the P group } \\
\text { and } 74 / 102 \\
(73 \%) \text { of the } \\
\text { E group had } \\
\text { one or more } \\
\text { episodes of } \\
\text { hypotension } \\
\text { (P=0.52) and } \\
\text { required one } \\
\text { or more } \\
\text { boluses of } \\
\text { vasopressor. }\end{array}$ & $\begin{array}{l}\text { Spinal } \\
\text { anesthesia } \\
\text { was induced } \\
\text { with the } \\
\text { patient in the } \\
\text { right lateral } \\
\text { position. } \\
\text { After skin } \\
\text { infiltration } \\
\text { with } \\
\text { lidocaine, a } \\
25 \text {-gauge } \\
\text { pencil point } \\
\text { needle was } \\
\text { inserted at } \\
\text { what was } \\
\text { estimated to } \\
\text { be L3-4 or } \\
\text { L4-5 } \\
\text { vertebral } \\
\text { interspace } \\
\text { and } 2.0-2.2 \\
\text { ml of } \\
\text { hyperbaric } \\
0.5 \% \\
\text { bupivacaine } \\
(10-20 \text { mg) } \\
\text { and fentanyl } \\
15 \text { mcg was } \\
\text { injected } \\
\text { intrathecally. } \\
\text { The }\end{array}$ & $\begin{array}{l}\text { There was } \\
\text { no } \\
\text { difference } \\
\text { between } \\
\text { groups in } \\
\text { the primary } \\
\text { outcome, } \\
\text { UA pH } \\
\text { ( } \mathrm{P}=0.70) \text {. In } \\
\text { the E group } \\
2 \text { cases had } \\
\text { a UA pH } \\
<7.0 \\
\text { compared } \\
\text { with no } \\
\text { cases in the } \\
\mathrm{P} \text { group } \\
(\mathrm{P}=0.50) .\end{array}$ & $\begin{array}{l}\text { One } \\
\text { neonate } \\
\text { in the E } \\
\text { group had } \\
\text { an } \\
\text { APGAR } \\
\text { score }<7 \\
\text { at } 1 \mathrm{~min} \\
\text { and } 5 \mathrm{~min} \\
\text { and one } \\
\text { neonate } \\
\text { in the P } \\
\text { group had } \\
\text { an } \\
\text { APGAR } \\
\text { score }<7 \\
\text { at } 1 \text { min; } \\
\text { all other } \\
\text { APGAR } \\
\text { score } \\
\text { were }>7 \text {. }\end{array}$ & $\begin{array}{l}\text { More } \\
\text { participants } \\
\text { had N/V in } \\
\text { the E group } \\
\text { than the } \mathrm{P} \\
\text { group } \\
(13 / 102 \\
(12.7 \%) \text { vs } \\
4 / 102(3.9 \%) \text {, } \\
\mathrm{P}=0.02) .\end{array}$ & \\
\hline $\begin{array}{l}\text { Prakash } \\
\text { et al., } \\
2010\end{array}$ & $\begin{array}{l}\text { Oxygen } 6 \mathrm{~L} / \mathrm{min} \\
\text { via face mask was } \\
\text { delivered after }\end{array}$ & $\begin{array}{l}\text { Each patient } \\
\text { received a } \\
10 \mathrm{ml} / \mathrm{kg} \mathrm{IV}\end{array}$ & $\begin{array}{l}\text { ASA 1 women } \\
\text { with singleton } \\
\text { pregnancies }\end{array}$ & $\begin{array}{l}\text { The mean } \\
\text { change in } \\
\text { systolic }\end{array}$ & $\begin{array}{l}\text { With } \\
\text { participants } \\
\text { in the left }\end{array}$ & $\begin{array}{l}\text { No } \\
\text { umbilical } \\
\text { artery pH }\end{array}$ & $\begin{array}{l}\text { Apgar } \\
\text { scores at } \\
1\end{array}$ & & \\
\hline
\end{tabular}




\begin{tabular}{|c|c|c|c|c|c|c|c|c|}
\hline & $\begin{array}{l}\text { spinal } \\
\text { administration and } \\
\text { positioning until } \\
\text { delivery }\end{array}$ & $\begin{array}{l}\text { infusion of } \\
\text { Lactated } \\
\text { Ringers } \\
\text { solution over } \\
15-20 \text { min } \\
\text { before spinal } \\
\text { anesthesia. }\end{array}$ & $\begin{array}{l}\text { scheduled for } \\
\text { elective } \\
\text { caesarean } \\
\text { delivery under } \\
\text { spinal } \\
\text { anesthesia }\end{array}$ & $\begin{array}{l}\text { pressure was } \\
\text { comparable } \\
\text { in the two } \\
\text { groups with } \\
\text { the minimum } \\
\text { being } 100 \text { in } \\
\text { the } \mathrm{E} \text { group } \\
\text { and } 93 \text { in the } \\
\mathrm{P} \text { group } \\
(\mathrm{P}=0.114) \\
\text { except at } 8 \\
\text { minutes } \\
\text { where } \mathrm{E} \\
\text { group was } \\
\text { lower } \\
(\mathrm{P}=0.004) .\end{array}$ & $\begin{array}{l}\text { lateral } \\
\text { position, } 2 \mathrm{ml} \\
0.5 \% \\
\text { Hyperbaric } \\
\text { Bupivacaine } \\
\text { was injected } \\
\text { intrathecally } \\
\text { at L3-4 via a } \\
25 \text { gauge } \\
\text { Quincke } \\
\text { needle. }\end{array}$ & $\begin{array}{l}\text { was less } \\
\text { than } 7.20 . \\
\text { Umbilical } \\
\text { artery and } \\
\text { venous } \mathrm{pH} \\
\text { were } \\
\text { significantly } \\
\text { lower in } \\
\text { group E } \\
\text { than in } \\
\text { group } \mathrm{P} \\
\text { (p=0.01 and } \\
\mathrm{P}=0.002) \\
\text { but never } \\
\text { reached true } \\
\text { acidosis }\end{array}$ & $\begin{array}{l}(\mathrm{p}=0.739) \\
, 5 \\
(\mathrm{p}=0.128) \\
\text { and } 10 \\
\text { min } \\
(\mathrm{p}=0.611) \\
\text { were } \\
\text { comparab } \\
\text { le in the } \\
\text { two } \\
\text { groups. } \\
\text { No } \\
\text { neonate } \\
\text { had an } \\
\text { Apgar } \\
\text { score }<7 \\
\text { at any } \\
\text { time. }\end{array}$ & \\
\hline $\begin{array}{l}\text { Mercier } \\
\text { et al., } \\
2013\end{array}$ & $\begin{array}{l}\text { Oxygen was } \\
\text { administered to all } \\
\text { participants via } \\
\text { nasal cannula of } \\
\text { unknown amount. }\end{array}$ & $\begin{array}{l}\text { intravenous } \\
\text { (IV) preload of } \\
15 \mathrm{ml} / \mathrm{kg} \text { of } \\
\text { Lactated } \\
\text { Ringer's } \\
\text { Solution (LR) } \\
\text { was given }\end{array}$ & $\begin{array}{l}\text { Age 18-years or } \\
\text { older, weight } \\
90 \mathrm{Kg} \text { or less, } \\
\text { height } 152 \mathrm{~cm} \text { or } \\
\text { greater, ASA I } \\
\text { or II, and term } \\
\text { singleton } \\
\text { pregnancy. }\end{array}$ & $\begin{array}{l}\text { The incidence } \\
\text { of } \\
\text { hypotension } \\
\text { was halved in } \\
\text { the } \mathrm{E}+\mathrm{P} \\
(37 \%) \text { group } \\
\text { when } \\
\text { compared } \\
\text { with the E } \\
(75 \%) \text { group } \\
(\mathrm{P}=0.02) \text {. } \\
\text { SBP values } \\
\text { after onset of } \\
\text { spinal } \\
\text { anesthesia } \\
\text { were not } \\
\text { significantly } \\
\text { different }\end{array}$ & $\begin{array}{l}\text { Spinal } \\
\text { anesthesia } \\
\text { was } \\
\text { performed at } \\
\text { the L2-L3 or } \\
\text { L3-L4 } \\
\text { interspace } \\
\text { with the } \\
\text { patient } \\
\text { sitting, using } \\
\text { a } 9 \mathrm{~cm} 25 \\
\text { gauge } \\
\text { whitacre } \\
\text { spinal } \\
\text { needle. } \\
11 \mathrm{mg} \text { of } \\
\text { hyperbaric } \\
0.5 \% \\
\text { Bupivacaine, }\end{array}$ & $\begin{array}{l}\text { Umbilical } \\
\text { venous and } \\
\text { arterial pH } \\
\text { values were } \\
\text { significantly } \\
\text { higher in } \\
\text { the } \mathrm{E}+\mathrm{P} \\
\text { group (7.24) } \\
\text { than in the } \\
\text { E group } \\
(7.19) \\
(\mathrm{P}=0.05) \text {. } \\
\text { The } \\
\text { incidence of } \\
\text { arterial pH } \\
<7.20 \text { was } \\
31 \% \text { higher } \\
\text { in the } \mathrm{E}+\mathrm{P}\end{array}$ & $\begin{array}{l}\text { Apgar } \\
\text { scores at } \\
1 \text { and } 5 \\
\text { min were } \\
\text { similar in } \\
\text { both } \\
\text { groups } \\
(\mathrm{p}=0.7) \\
\text { and were } \\
\text { never less } \\
\text { than } 7 .\end{array}$ & $\begin{array}{l}\text { Low } \\
\text { venous and } \\
\text { arterial pH } \\
\text { values } \\
\text { were } \\
\text { associated } \\
\text { only with } \\
\text { the E group } \\
\text { assignment } \\
\text { and spinal } \\
\text { anesthesia } \\
\text { to delivery } \\
\text { times } \\
\text { longer than } \\
33 \text { min. }\end{array}$ \\
\hline
\end{tabular}




\begin{tabular}{|c|c|c|c|c|c|c|c|}
\hline & & & & $\begin{array}{l}\text { between the } \\
\text { two groups. }\end{array}$ & $\begin{array}{l}2.5 \mathrm{mcg} \\
\text { Sufentanil } \\
\text { and } 0.1 \mathrm{mg} \\
\text { morphine } \\
\text { was injected } \\
\text { through the } \\
\text { spinal } \\
\text { needle. }\end{array}$ & $\begin{array}{l}\text { group and } \\
63 \% \text { in the } \\
\text { E group } \\
(P=0.09) .\end{array}$ & \\
\hline $\begin{array}{l}\text { Moslem } \\
\text { i, F., \& } \\
\text { Rasooli, } \\
\text { S. } \\
\text { (2015). }\end{array}$ & Not reported & $\begin{array}{l}\text { Prior to spinal } \\
\text { anesthesia all } \\
\text { participants } \\
\text { received a } 500 \\
\text { ml crystalloid } \\
\text { bolus. }\end{array}$ & $\begin{array}{l}\text { healthy } \\
\text { pregnant } \\
\text { women with } \\
\text { gestational age } \\
\text { of } 36 \text { weeks or } \\
\text { higher and non- } \\
\text { emergency c- } \\
\text { section }\end{array}$ & $\begin{array}{l}\text { SBP after } \\
\text { anesthesia } \\
\text { every } 2 \text { and } \\
\text { every } 5 \\
\text { minutes were } \\
\text { different } \\
(\mathrm{P}>0.050) \text { in } \\
\text { the Ph and } \mathrm{P} \\
\text { groups. }\end{array}$ & $\begin{array}{l}\text { participants } \\
\text { then } \\
\text { received } \\
\text { spinal } \\
\text { anesthesia } \\
\text { by an } \\
\text { anesthesiolo } \\
\text { gist in the } \\
\text { sitting } \\
\text { position } \\
\text { from L4/5 or } \\
\text { L3/4 inter- } \\
\text { vertebral } \\
\text { spaces with } \\
2.5 \mathrm{ml} \text { of } \\
\text { Bupivacaine } \\
0.5 \% \\
(12.5 \mathrm{mg}) \\
\text { and } 2.5 \mathrm{mcg} \\
\text { of } \\
\text { Sufentanil. }\end{array}$ & $\begin{array}{l}\text { UA } \\
\text { (umbilical } \\
\text { artery) } \\
\text { blood gas } \\
\text { analysis } \\
\text { showed a } \\
\text { significant } \\
\text { difference } \\
\text { in pH } \\
\text { between the } \\
\text { Ph and P } \\
\text { groups. 2 } \\
\text { neonates in } \\
\text { the Ph } \\
\text { group, } 7 \text { in } \\
\text { the E group } \\
\text { and } 5 \text { in the } \\
\text { P group had } \\
\text { acidosis. } \\
\text { Acidosis } \\
\text { was } \\
\text { significantly } \\
\text { lower in } \\
\text { phenylephri } \\
\text { ne group } \\
\text { (P=0.043) }\end{array}$ & $\begin{array}{l}\text { There } \\
\text { was no } \\
\text { significan } \\
\mathrm{t} \\
\text { difference } \\
\text { in the 1 } \\
\text { min } \\
\text { APGAR } \\
\text { scores } \\
\text { between } \\
\text { all of the } \\
\text { groups. } \\
\text { There } \\
\text { was a } \\
\text { significan } \\
\mathrm{t} \\
\text { difference } \\
\text { in the } 5 \\
\text { min } \\
\text { APGAR } \\
\text { scores } \\
\text { was } \\
\text { shown to } \\
\text { be better } \\
\text { with } \\
\text { group Ph } \\
\text { and E } \\
\text { than with }\end{array}$ \\
\hline
\end{tabular}




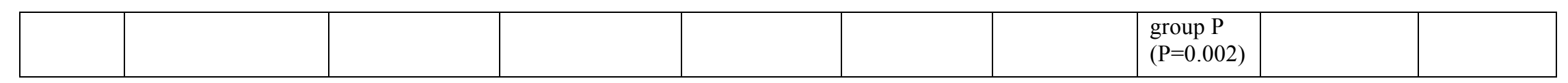

